\title{
PRELIMINARY EVALUATION OF THE GROUND-WATER-FLOW SYSTEM \\ 央 \\ s \\ IN THE TWIN CITIES METROPOLITAN \\ AREA, MINNESOTA
}

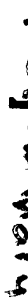

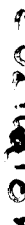

U. S. GEOLOGICAL SURVEY

WATER-RESOURCES INVESTIGATIONS 82-44

PREPARED IN COOPERATION WITH THE

METROPOLITAN COUNCIL OF THE TWIN CITIES,

MINNESOTA DEPARTMENT OF NATURAL RESOURCES, MINNESOTA GEOLOGICAL SURVEY

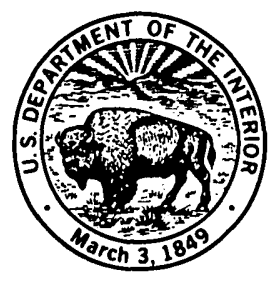


PRELIMINARY EVALUATION OF THE GROUND-WATER-FLOW SYSTEM

IN THE TWIN CITIES METROPOLITAN AREA, MINNESOTA

By J. H. Guswa, D. I. Siegel, and D. C. Gillies

\section{U.S. GEOLOGICAL SURVEY}

Water-Resources Investigations 82-44

Prepared in cooperation with the

METROPOLITAN COUNCIL OF THE TWIN CITIES,

MINNESOTA DEPARTMENT OF NATURAL RESOURCES,

MINNESOTA GEOLOGICAL SURVEY

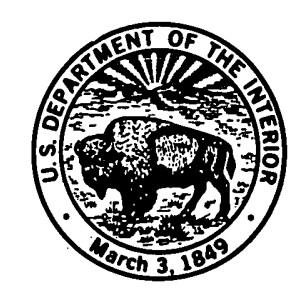

August 1982

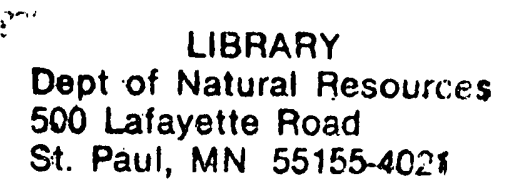




\section{UNITED STATES DEPARTMENT OP THE INTERIOR}

JAMES G. WATT, Secretary

\section{GEOLOGICAL SURVEY}

Dallas L. Peck, Director

For additional information

write to:

District Chief

U.S. Geological Survey

702 Post Office Building

St. Paul, Minnesota 55101

Telephone: (612).725-7841
Copies of this report can be purchased from:

Open-File Services Section Wester Distribution Branch

U.S. Geological Survey

Box 25425, Federal Center

Lakewood, Colorado 80225

Telephone: (303) 234-5888 


\section{CONTENTS}

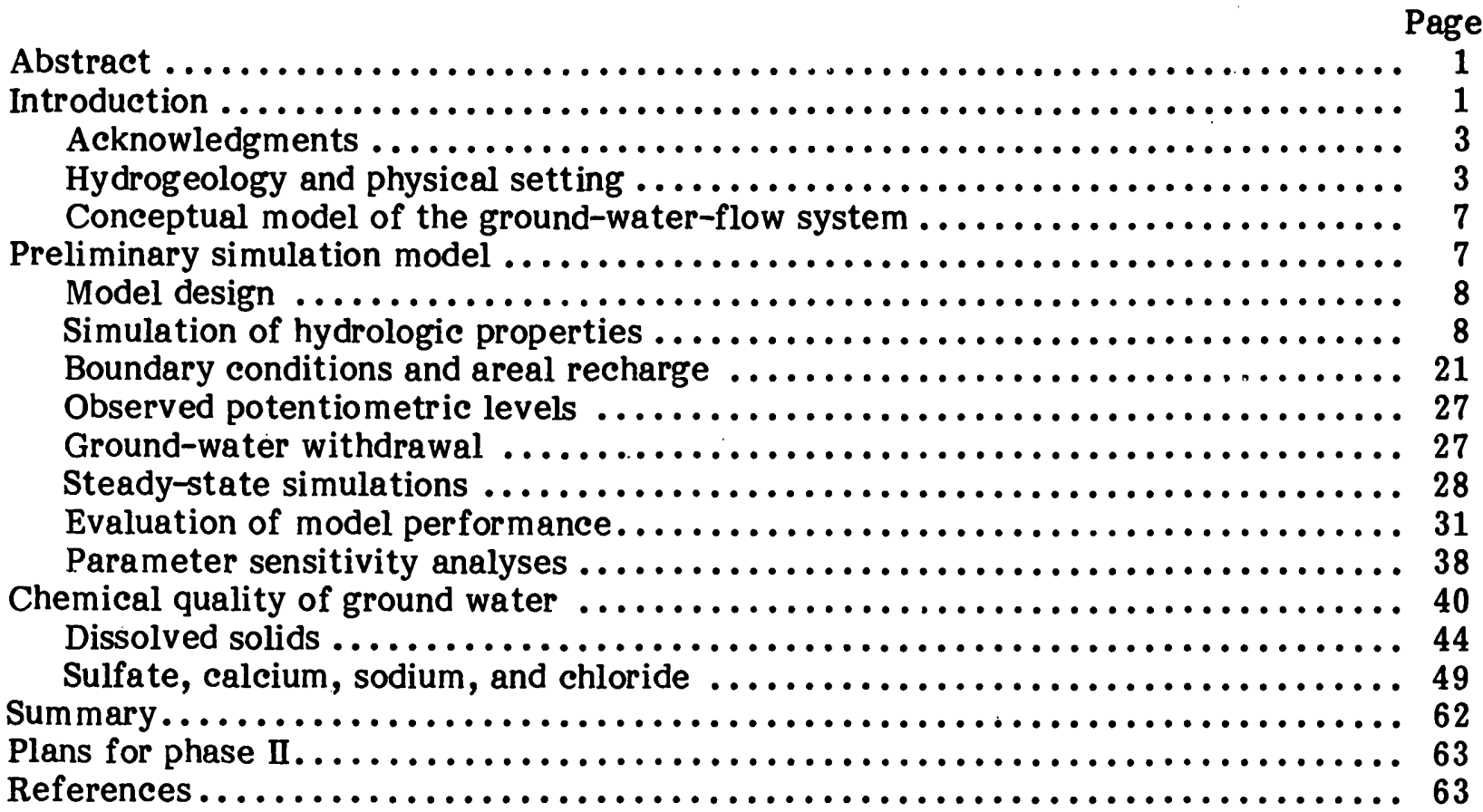

\section{ILLUSTRATIONS}

Figure 1. Map showing location of Twin Cities metropolitan area,

Minnesota ...................................... 2

2. Diagram of hydrogeologic units defined for this study $\ldots \ldots \ldots \ldots \ldots, 6$

3. Finite-difference grid used for the preliminary model $\ldots \ldots \ldots \ldots \ldots \ldots, 9$

4. Diagram of generalized layering scheme for preliminary model ...... 10

5-9. Maps showing thickness of:

5. Mount Simon-Hinckley aquifer..................... 12

6. Eau Claire confining unit $\ldots \ldots \ldots \ldots \ldots \ldots \ldots \ldots \ldots \ldots \ldots, 13$

7. Ironton-Galesville aquifer... ..................... 14

8. St. Lawrence-Franconia confining unit $\ldots \ldots \ldots \ldots \ldots \ldots \ldots \ldots$

9. Prairie du Chien-Jordan aquifer.................... 16

10. Map showing areal extent of basal St. Peter confining unit $\ldots \ldots \ldots \ldots, 17$

11. Map showing thickness of St. Peter aquifer $\ldots \ldots \ldots \ldots \ldots \ldots \ldots \ldots \ldots$

12. Map showing thickness of Decorah-Platteville-Glenwood confining unit ................................... 19

13. Map showing uppermost model layer at each model grid block ...... 20

14-18. Maps showing location of head-dependent flux boundaries:

14. Model layer 1 (Mount Simon-Hinckley aquifer)........... 22

15. Model layer 2 (Ironton-Galesville aquifer)............. 23

16. Model layer 3 (Prairie du Chien-Jordan aquifer) ......... 24

17. Model layer 4 (St. Peter aquifer) $\ldots \ldots \ldots \ldots \ldots \ldots \ldots \ldots \ldots .25$

18. Model layer 5 (drift) .......................... 26 


\section{ILLUSTRATIONS}

Figure 19. Map showing summary of average withdrawal rates for

Page Mount Simon-Hinckley aquifer, 1971-77 ................. 29

20. Map showing summary of average withdrawal rates for

Prairie du Chien-Jordan aquifer, 1971-77 ................. 30

21. Map showing summary of residuals for 1885 simulation, layer 1 (Mount Simon-Hinckley aquifer) ................. 32

22. Map showing summary of residuals for 1885 simulation, layer 3 (Prairie du Chien-Jordan aquifer) .................. 33

23-26. Maps showing summary of residuals for 1971-77 simulation:

23. Layer 1 (Mount Simon-Hinckley aquifer) ............. 34

24. Layer 3 (Prairie du Chien-Jordan aquifer)............. 35

25. Layer 4 (St. Peter aquifer).................... 36

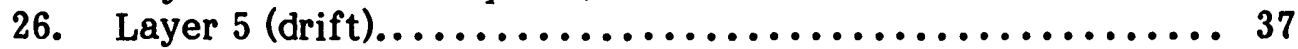

27. Piper diagram of median concentrations of major dissolved constituents in water from the principle aquifers in the

Twin Cities metropolitan area ........................

28. Map showing the eastern extent of the Des Moines Lobe drift and subcrop of the Jordan Sandstone .................... 45

29-31. Maps showing lines of equal concentration of dissolved solids in water from the:

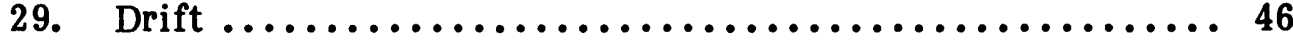

30. Jordan Sandstone........................ 47

31. Mount Simon-Hinckley aquifer ................. 48

32-34. Maps showing lines of equal concentration of dissolved sulfate in water from the:

32. Drift .............................. 50

33. Jordan Sandstone......................... 51

34. Mount Simon-Hinckley aquifer ................. 52

35-37. Maps showing lines of equal concentration of dissolved calcium in water from the:

35. Drift ............................... 53

36. Jordan Sandstone......................... 54

37. Mount Simon-Hinckley aquifer .................. 55

38-40. Maps showing lines of equal concentration of dissolved sodium in water from the:

38. Drift $\ldots \ldots \ldots \ldots \ldots \ldots \ldots \ldots \ldots \ldots \ldots \ldots \ldots \ldots \ldots \ldots \ldots \ldots$

39. Jordan Sandstone.......................... 57

40. Mount Simon-Hinckley aquifer .................. 58

41. Map showing concentration of chloride in water from the drift ...... 59

42. Map showing concentration of chloride in water from the Jordan Sandstone.............................. 60

43. Map showing lines of equal concentration of chloride in water from the Mount Simon-Hinckley aquifer ................. 61 


\section{TABLES}

Table 1. Geologic units and their water-bearing characteristics ............ 4

2. Relationship between model layers and hydrogeologic units .......... 11

3. Values of hydraulic parameters used in preliminary-model

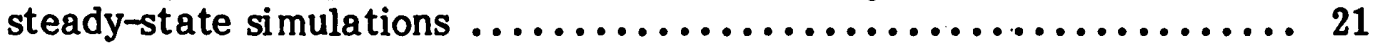

4. Average ground-water withdrawals, $1971-77 \ldots \ldots \ldots \ldots \ldots \ldots \ldots \ldots . \ldots 28$

5. Parameters evaluated in preliminary-model sensitivity analyses ....... 39

6. Number of model nodes where the absolute value of head change caused by a 10-percent increase in parameter value is greater than 2.0 feet and 10.0 feet ........................... 40

7. Median and range of concentrations for selected constituents in water from principal bedrock units and drift in the Twin Cities metropolitan area

CONVERSION FACTORS

Multiply inch-pound units

inch (in)

foot (ft)

square mile $\left(\mathrm{mi}^{2}\right)$

cubic foot per second $\left(\mathrm{ft}^{3} / \mathrm{s}\right)$

million gallons per day ( $\mathrm{Mgal} / \mathrm{d})$

micromho per centimeter

(jmho/cm)
By $\quad$ To obtain SI units

25.4 millimeter $(\mathrm{mm})$

0.3048 meter $(\mathrm{m})$

2.590 square kilometer $\left(\mathrm{km}^{2}\right)$

0.02832 cubic meter per second $\left(\mathrm{m}_{3}^{3} / \mathrm{s}\right)$

0.04381 cubic meter per second $(\mathrm{m} / \mathrm{s})$

1.000 microsiemens per centimeter ( $\mathrm{sS} / \mathrm{cm})$ 


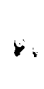




\title{
PRELIMINARY EVALUATION OF THE GROUND-WATER-FLOW SYSTEM IN THE TWIN CITIES METROPOLITAN AREA, MINNESOTA
}

By J. H. Guswa, D. I. Siegel, and D. C. Gillies

\begin{abstract}
A preliminary quasi-three-dimensional finite-difference ground-water-flow model of the seven-county Twin Cities Metropolitan area was constructed and used to evaluate parameter sensitivity and adequacy of available data. Fourteen geologic units that underlie the study area were grouped into nine hydrogeologic units and were incorporated into a five-layer model. The layers in the simulation model include the Mount SimonHinckley, Ironton-Galesville, Prairie du Chien-Jordan, and St. Peter aquifers, and the drift.

Sensitivity analyses were made for 19 parameter and boundary-condition specifications. Model results are most sensitive to recharge and withdrawal rates and to hydrogeologic variations related to drift-filled bedrock valleys. Analyses of available data and results of steady-state simulations indicate that critical data needs for improving the simulation model include spatial and temporal variations in ground-water withdrawals and potentiometric levels, and hydraulic properties of drift filling or partly filling bedrock valleys.

Areal distribution of calcium, sodium, sulfate, and chloride concentrations were analyzed to provide information on the hydrologic and geochemical relationships between aquifers. Ground water is generally of the calcium magnesium bicarbonate type. Concentration of dissolved solids in water from the Jordan Sandstone and Mount Simon-Hinckley aquifer generally decreases from southwest to northeast across the study area. This decrease probably reflects differences in the quality of recharge water and geochemical processes within the aquifers, such as ion exchange.
\end{abstract}

\section{INTRODUCTION}

This report describes the results of the first phase of a three-phase study of the ground-water-flow system in the Twin Cities metropolitan area (fig. 1), an area of approximately $3,000 \mathrm{mi}^{2}$. The objectives of this study are to (1) develop a detailed understanding of the ground-water-flow system and the geologic framework within which it operates, as described in Norvitch and others (1973), (2) apply this detailed understanding to an evaluation of the hydrologic effects of continued development of the ground-water resources by use of a quasi-three-dimensional flow model, and (3) provide State and local water managers and planners the means to evaluate alternative development and management schemes that they may propose. The first phase of the study included the formulation of a conceptual model of the ground-water-flow system and its relationship to the hydrogeology, construction of a preliminary finite-difference digital model of ground-water flow, analysis of model parameter and boundary-condition sensitivity, evaluation of the performance of the preliminary flow model, and description of the general quality of ground water in the Twin Cities area. 


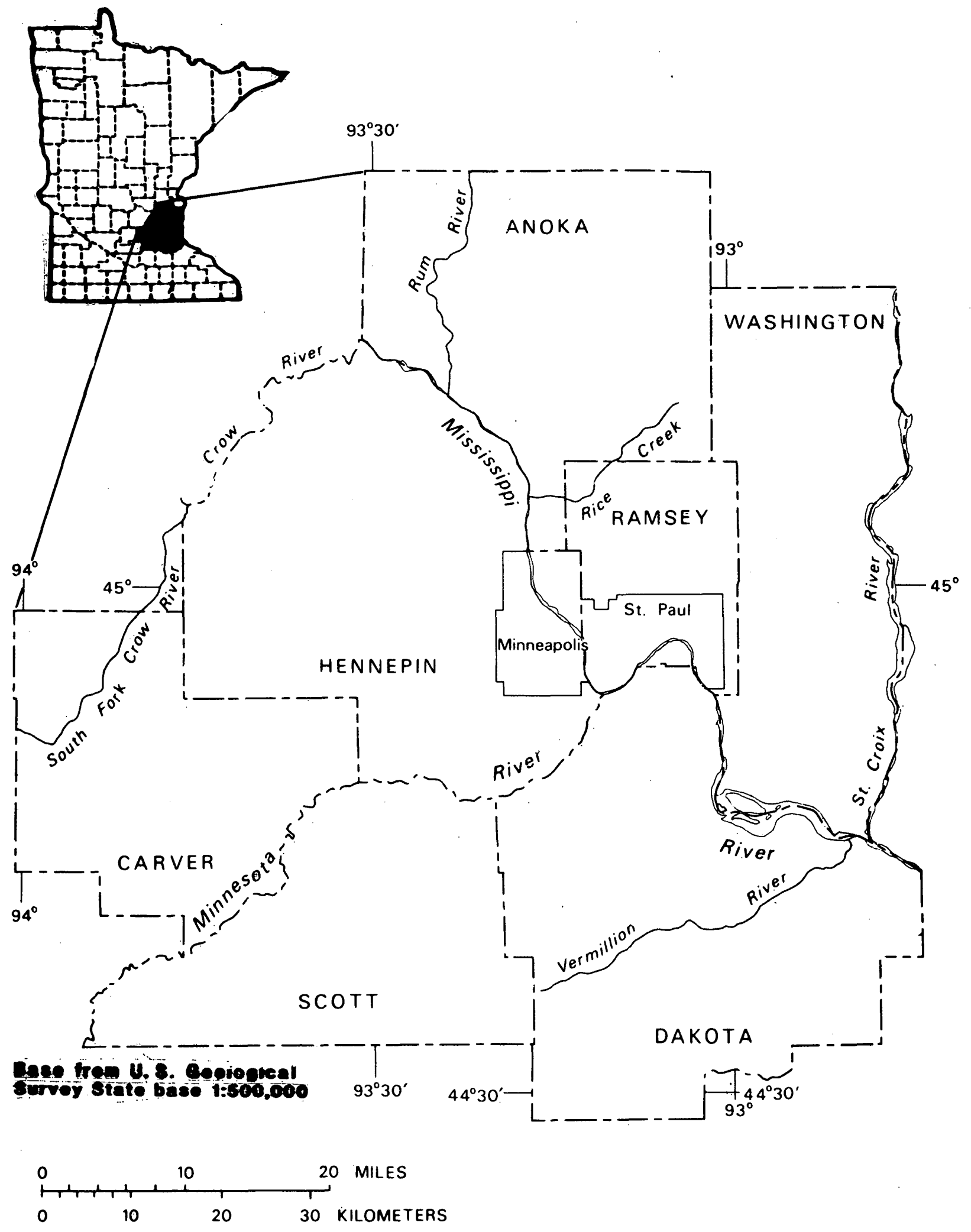

Fustere 1.--Lecatuen of Twla Cities mefroponten area, Mibaeseta 
The second and third phases of this study are designed to improve the performance of the digital model through continued testing, collection of additional hydrologic data, evaluation of the conceptual model, and analysis of the effects of alternative development and management schemes that State and local water managers and planners may propose.

\section{Acknowledgments}

This study was done in cooperation with the Metropolitan Council of the Twin Cities and the Minnesota Department of Natural Resources, Division of Waters. The Minnesota Geological Survey, under a contractual agreement with the Metropolitan Council, provided structure-contour, isopach, and sand-percentage maps of the geologic units. Much of the information on ground-water use was extracted from the files of the Department of Natural Resources.

\section{Hydrogeology and Physical Setting}

The following is a generalized description of the hydrogeology of the study area as it pertains to construction of the preliminary flow model. A detailed discussion of the source, occurrence, and movement of ground water in the area is contained in a report by Norvitch and others (1973).

The study area lies on a geologic structure that is commonly referred to as the Twin Cities artesian basin. Rocks of Precambrian, Cambrian, and Ordovician age were deposited in a north-south trending trough in the Precambrian rock surface. The deepest part of the trough lies directly beneath the Twin Cities. The present land surface is largely composed of drift from the Wisconsin Glaciation of the Pleistocene Epoch. There is no record of deposition in the Twin Cities area from Late Ordovician to Quaternary time. The geologic units and their water-bearing characteristics are described in table 1. A complete discussion of the geology and geologic history of the Twin Cities area is presented in reports by Mossler (1972), and Sims and Morey (1972).

Based on the present understanding of the water-bearing characteristics of the 14 geologic units that underlie the Twin Cities area, nine hydrogeologic units were defined for this study. These nine hydrogeologic units and their relationship to the geologic units are also indicated in table 1 . The vertical distribution of the nine units is illustrated in the simplified hydrogeologic section (fig. 2).

Several of the hydrogeologic units are dissected by bedrock valleys whose origin, occurrence, depth, and stratigraphy is not clearly known (fig. 2). The bedrock valleys are either partly. or totally filled with drift or recent alluvial deposits. These valleys are important because (1) they provide hydraulic continuity between deeper bedrock formations and surficial deposits and (2) they provide hydraulic connection between the deeper bedrock aquifers and the major rivers in the study area. Where these river valleys intersect the bedrock aquifers they superimpose a local system of recharge or discharge on the generally northwest to southeast regional hydraulic gradient.

Major streams in the area include the Mississippi, Minnesota, and St. Croix Rivers. During 1928-78, the average discharge of the Mississippi River, including the tributary flows of the Minnesota and St. Croix Rivers, where it leaves the study area (Prescott, Wis.), was $16,200 \mathrm{ft}^{3} / \mathrm{s}$.

The climate is predominantly continental. Average annual precipitation and evapotranspiration are 28.3 and 22.5 inches, respectively, (Norvitch and others, 1973 ). 
Table 1.-Geologic units and their water-bearing

\begin{tabular}{|c|c|c|c|}
\hline System & Geologic unit & $\begin{array}{l}\text { Approximate } \\
\text { range in } \\
\text { thickness } \\
\text { (feet) }\end{array}$ & Description \\
\hline $\begin{array}{l}\text { Quarter- } \\
\text { nary }\end{array}$ & $\begin{array}{l}\text { Undifferentiated } \\
\text { glacial drift. }\end{array}$ & $0-400$ & $\begin{array}{l}\text { Till, outwash and valley-train sand and gravel, lake } \\
\text { deposits, and alluvium; vertical and horizontal } \\
\text { distribution of units is complex. }\end{array}$ \\
\hline \multirow{5}{*}{$\begin{array}{l}\text { Ordovi- } \\
\text { cian }\end{array}$} & Decorah Shale. & $0-95$ & Shale, bluish-green to bluish-gray; blocky. \\
\hline & $\begin{array}{l}\text { Platteville } \\
\text { Limestone. }\end{array}$ & $0-35$ & $\begin{array}{l}\text { Dolomitic limestone and dolomite, dark gray, hard, } \\
\text { thin-bedded to medium-bedded. }\end{array}$ \\
\hline & Glenwood Shale. & $0-18$ & $\begin{array}{l}\text { Shale, bluish-gray to bluish-green; generally soft } \\
\text { but becomes dolomitic and harder to the east. }\end{array}$ \\
\hline & $\begin{array}{l}\text { St. Peter } \\
\text { Sandstone. }\end{array}$ & $0-150$ & $\begin{array}{l}\text { Sandstone, white, fine- to medium-grained, well- } \\
\text { sorted, quartzose; 5-50 feet of siltstone and shale } \\
\text { near.bottom of formation. }\end{array}$ \\
\hline & $\begin{array}{l}\text { Prairie du Chien } \\
\text { Group. }\end{array}$ & $0-250$ & $\begin{array}{l}\text { Dolomite, sandstone, sandy dolomite; light brown, } \\
\text { buff, gray; thinly to thickly bedded. }\end{array}$ \\
\hline \multirow{5}{*}{$\begin{array}{l}\text { Cam- } \\
\text { brian }\end{array}$} & Jordan Sandstone. & $0-100$ & $\begin{array}{l}\text { Sandstone, white to yellowish, fine- to coarse- } \\
\text { grained, massive to bedded, cross-bedded in } \\
\text { places, quartzose; loosely to well cemented. }\end{array}$ \\
\hline & $\begin{array}{l}\text { St. Lawrence } \\
\text { Formation. }\end{array}$ & $0-65$ & $\begin{array}{l}\text { Dolomitic siltstone and fine-grained dolomitic } \\
\text { sandstone, gray to greenish, glauconitic. }\end{array}$ \\
\hline & $\begin{array}{l}\text { Franconia } \\
\text { Sandstone. }\end{array}$ & $0-200$ & $\begin{array}{l}\text { Sandstone, gray to greenish, glauconitic, very fine } \\
\text { grained; some interbedded micaceous shale and } \\
\text { dolomitic sandstone. }\end{array}$ \\
\hline & $\begin{array}{l}\text { Ironton } \\
\text { Sandstone. }\end{array}$ & & $\begin{array}{l}\text { Sandstone, yellow to white, medium- to coarse- } \\
\text { grained, poorly cemented. }\end{array}$ \\
\hline & $\begin{array}{l}\text { Galesville } \\
\text { Sandstone. }\end{array}$ & & $\begin{array}{l}\text { Sandstone, yellow to white, medium- to coarse- } \\
\text { grained, poorly cemented. }\end{array}$ \\
\hline \multirow[t]{2}{*}{. } & $\begin{array}{l}\text { Eau Claire } \\
\text { Sandstone. }\end{array}$ & $0-150$ & $\begin{array}{l}\text { Sandstone, siltstone, and shale, gray to reddish- } \\
\text { brown, fossiliferous. }\end{array}$ \\
\hline & $\begin{array}{l}\text { Mount Simon } \\
\text { Sandstone. }\end{array}$ & $\begin{array}{l}\text { As much as } \\
200\end{array}$ & $\begin{array}{l}\text { Sandstone, gray to pink, medium- to coarse-grained. } \\
\text { Some pebble zones and thin shalely beds. }\end{array}$ \\
\hline $\begin{array}{l}\text { Precam- } \\
\text { brian }\end{array}$ & $\begin{array}{l}\text { Hinckley } \\
\text { Sandstone. }\end{array}$ & $\begin{array}{c}\text { As much as } \\
200\end{array}$ & $\begin{array}{l}\text { Sandstone, buff to red, medium- to coarse-grained; } \\
\text { well sorted ańd cemented. }\end{array}$ \\
\hline
\end{tabular}


characteristics (modified from Stone, 1965)

Water-bearing characteristics

Hydrogeologic

units defined

for this study

Distribution of aquifers and confining beds within drift is poorly known.

Stratified well-sorted deposits of sand and gravel yield moderate to large Drift. supplies of water to wells $(240$ to $2,000 \mathrm{gal} / \mathrm{min})$.

Confining bed.

Fractures and solution cavities in rock generally yield small supplies to wells

(less than $20 \mathrm{gal} / \mathrm{min}$ ). Not considered to be an important source of water

Decorah-Platte-

in area of study.

ville-Glenwood confining unit.

Confining bed; locally some springs issue from the Glenwood-Platteville contact in the river bluffs.

Most wells completed in the sandstone are of small diameter and used for domestic supply. They yield 9 to $100 \mathrm{gal} / \mathrm{min}$. Water occurs under both confined and unconfined conditions. Confining bed near bottom of formation seems extensive and hydraulically separates sandstone from underlying Prairie du Chien-Jordan aquifer. Not considered to be an important source for public supplies in area of study.

St. Peter

aquifer.

Basal St. Peter confining unit.

Prairie du Chien: Permeability is due to fractures, joints, and solution cavities in the rock. Yields small to large supplies of water to wells. Pumping rates of up to $1,800 \mathrm{gal} / \mathrm{min}$ have been obtained.

Jordan: Permeability is mostly intergranular but may be due to joint partings in cemented parts. Main source of water for public supply in metropolitan area. Recorded yields are from 36 to $2,400 \mathrm{gal} / \mathrm{min}$.

Prairie du Chien-Jordan aquifer: Supplies about 75 percent of ground water pumped in the metropolitan area. Yields from 85 to $2,765 \mathrm{gal} / \mathrm{min}$.

Confined unit regionally. May yield small quantities to domestic wells locally.

Confining unit regionally. May yield small quantities to domestic wells confining unit. locally.

An important aquifer beyond the limits of the Prairie du Chien-Jordan aquifer. Yields of wells range from 40 to $400 \mathrm{gal} / \mathrm{min}$.

Ironton-Galesville aquifer.

Confining unit regionally. May yield small quantities to domestic wells locally.

Eau Claire confining unit.

Secondary major aquifer in the area of study. Supplies about 10 percent of ground water pumped in the metropolitan area. Recorded yields range from 125 to $2,000 \mathrm{gal} / \mathrm{min}$.

Mount Simon-

HinckleyAquifer. 


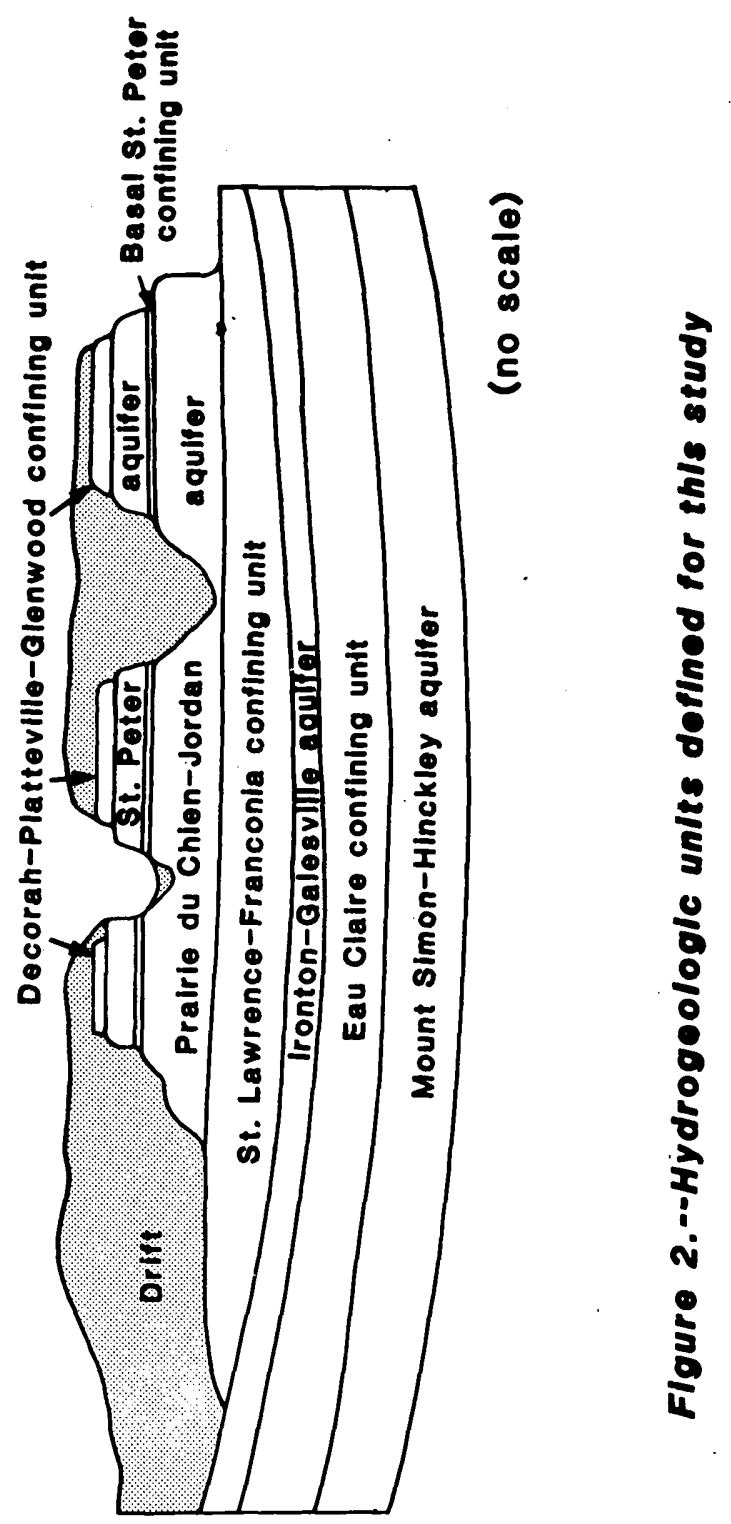




\section{Conceptual Model of the Ground-Water-Flow System}

A conceptual model of the ground-water system was formulated before construction of the preliminary digital model. The conceptual model contains qualitative descriptions of the characteristics and behavior of the system and simplifying assumptions that must be made to facilitate computer modeling. The major elements of the conceptual model are:

1. Ground-water flow is predominantly horizontal within the aquifer units and vertical within the confining units.

2. The ground-water system is recharged by precipitation that infiltrates to the saturated zone and then leaks vertically downward to deeper aquifers.

3. Water is pumped from each of the aquifers in the system.

4. The amount of water that moves across the base of the Hinckley Sandstone is small and the base can be treated as a no-flow boundary.

5. Water flows between the aquifer system and the Mississippi, Minnesota, and St. Croix Rivers as a function of the difference between the aquifer head and the river stage.

6. Aquifers discharge water through seepage faces along the banks of the Mississippi, Minnesota, and St. Croix Rivers.

7. Natural boundaries of some hydrogeologic units in the aquifer system lie outside the Twin Cities study area, and ground water flows laterally across the arbitrarily imposed model boundaries.

\section{PRELIMINARY SIMULATION MODEL}

The nine hydrogeologic units defined for this study and the hydrologic stresses and boundary conditions identified for the conceptual model of the ground-water-flow system were incorporated into a digital finite-difference model. The purpose of the preliminary model was threefold: (1) to gain a better understanding of the behavior of the groundwater system and improve the conceptual model, (2) to determine the adequacy of available data for the construction of a flow model, and (3) to determine the relative importance of various hydrologic parameters by testing their sensitivity in the model simulation. Such improved understanding of the system and knowledge of parameter sensitivity should greatly enhance efforts to collect additional data and refine that initially available.

The computer program used was that developed by Trescott (1975), and Trescott and Larson (1976). The 1975 version of the model program was subsequently modified by S. P. Larson of the U.S. Geological Survey to allow simulation of the interaction of streams and artificial drains with the ground-water system. In the preliminary model for the Twin Cities, the program's stream-simulation option was also used to simulate other head-dependent-flux boundaries, such as springs and flow across the lateral boundaries of the model area. Another modification of the model program was the addition of an alternative solution method, the slice-successive over-relaxation procedure (SSOR) developed by S. P. Larson (oral commun., 1979). Comparison of preliminary simulations indicated that the SSOR procedure was slightly more efficient than the strongly implicit procedure (SIP), which was the original solution method of the model program. 


\section{Model Design}

The modeled area was subdivided by use of a rectangular finite-difference grid with uneven spacing (fig. 3). The grid contains 34 rows and 37 columns and horizontal grid spacings range from 4,000 to 20,000 feet. The smaller grid spacings are generally in the central part of the modeled area where the most detail is needed to simulate bedrock valleys, streams, and large ground-water withdrawals. The larger grid spacings are generally near the northern, western, and southern boundaries of the modeled area where the hydrogeology is less well known and present and anticipated withdrawals are small. By convention, nodes are located at the centers of the grid blocks. Aquifer properties and stresses are assigned to the nodes and are assumed to represent average conditions within the grid block. Any specific node or block may be referenced by citing its row (i), column $(j)$, and layer ( $k$ ) location.

The preliminary model has five layers and four intervening confining-unit representations. Because flow in the aquifer system is interpreted to be principally horizontal within the aquifers and principally vertical within the confining units, a "quasi-threedimensional model" (Bredehoeft and Pinder, 1970) was constructed. In this approach, confining units are not explicitly included as layers in the model, but vertical flow through them and between aquifers is incorporated by use of leakance coefficients. These coefficients are equal to the vertical hydraulic conductivity of the confining unit divided by its thickness. The quasi three-dimensional approach also assumes that storage in confining units is negligible.

The hydrogeologic units shown in figure 2 were incorporated into the model according to the relationships shown in table 2 and figure 4. Each hydrogeologic unit, except for the drift, is contained in only one layer or confining-unit representation in the model, but each model layer does not necessarily contain only one hydrogeologic unit. For example, the Prairie du Chien-Jordan aquifer is always in model layer 3 , but this layer also contains part of the drift. The drift occupies that part of the layer where the Prairie du Chien-Jordan aquifer is missing because of erosion or nondeposition. Similarly, the St. Lawrence-Franconia confining unit is always in confining-unit representation 2-3, but this confining-unit representation also contains part of the drift (fig. 4).

The drift is treated differently in the preliminary model from the other hydrogeologic units in that it is simulated in four model layers ( 2 through 5 ) and three confiningunit representations (2-3, 3-4, and 4-5). This was necessary because the drift interrupts the continuity of bedrock aquifers and confining units where it fills bedrock valleys and where the bedrock units subcrop beneath it. Thus, the drift is treated as both an aquifer and a confining unit depending on its relation in space to the bedrock units. This was done by using average values of transmissivity and vertical hydraulic conductivity.

\section{Simulation of Hydrologic Properties}

The geologic information used to construct the preliminary model was based on maps prepared by the Minnesota Geological Survey and is summarized in figures 5 through 12. These figures show how the thickness of each hydrogeologic unit was zoned for model construction. They also show the areas where each bedrock unit is missing because of structural features of the Twin Cities basin or because of erosion. In many of these areas, the missing bedrock has been replaced by drift. Although the spatial variability of aquifer and confining-unit thickness was not simulated in the preliminary model, this infor mation was needed to (1) establish the lithology and geometry of each model layer and 


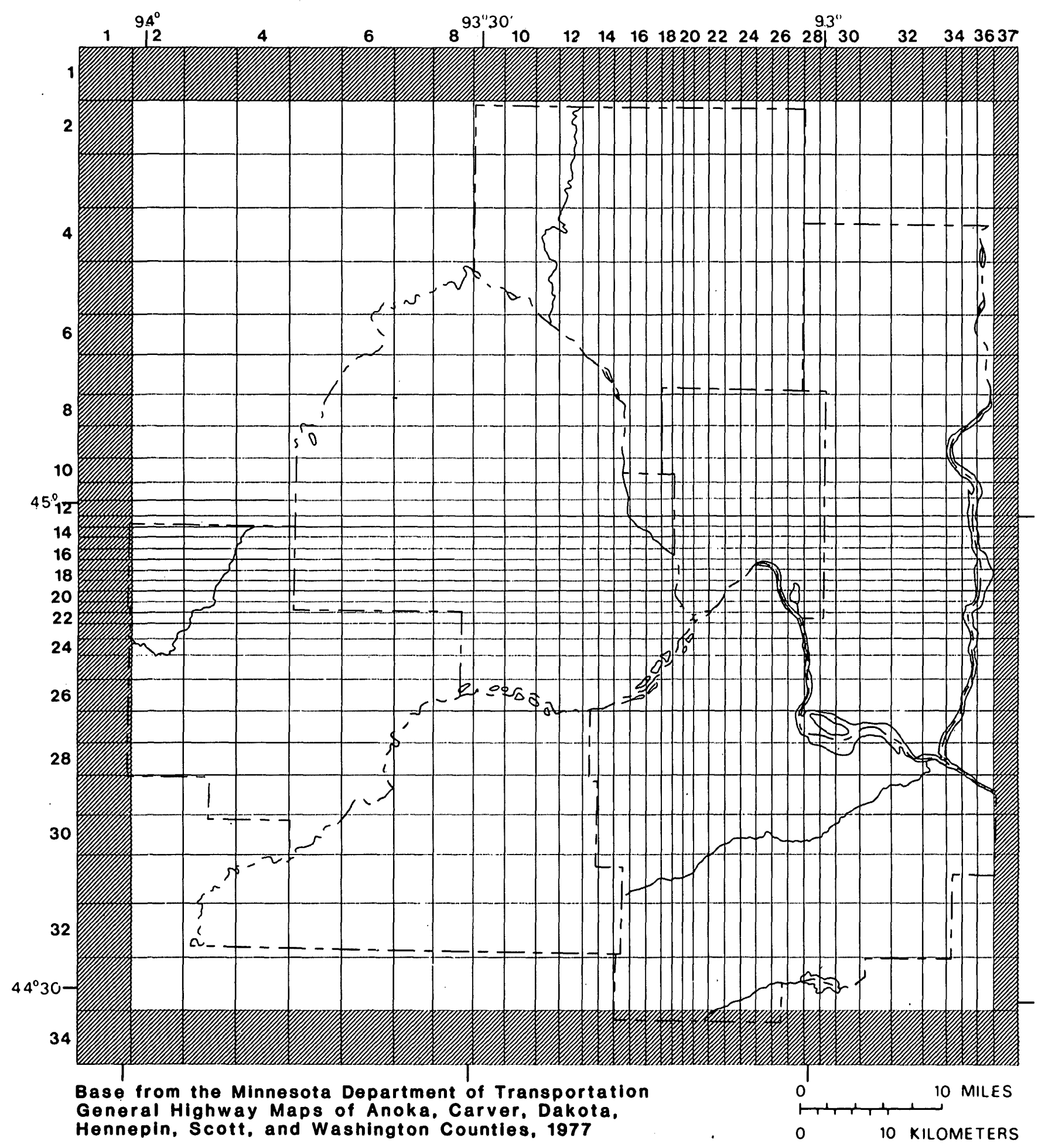

Figure 3.--Finite-difference grid used for the preliminary model 


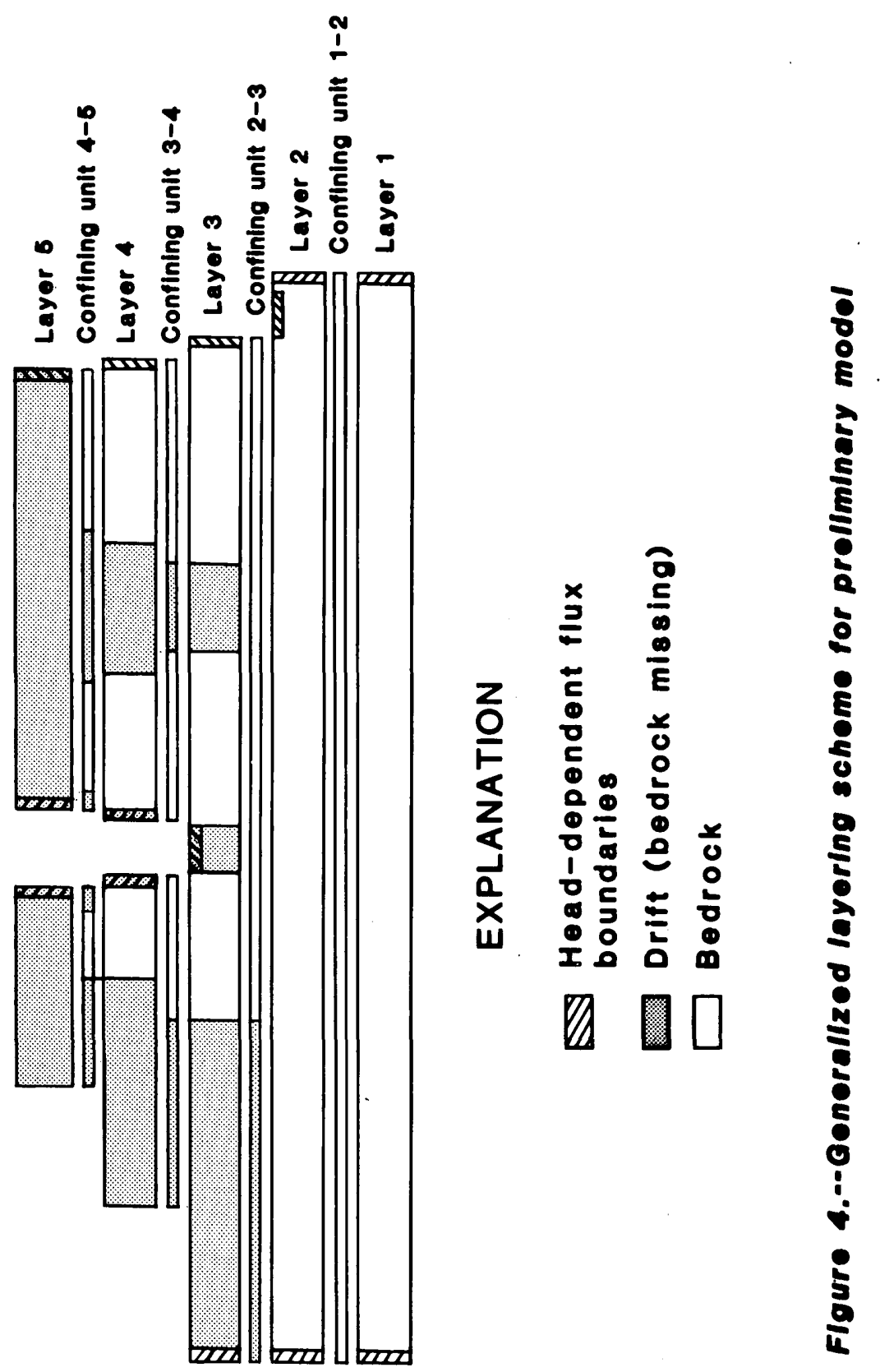


confining-unit representation, (2) assign appropriate boundary conditions to each model layer, and (3) identify where the continuity of aquifers and confining units is interrupted by drift. Figure 13 shows the uppermost model layer present at each block of the finitedifference grid. Comparison of figures 4 and 13 indicates that the upper layers of the model are not continuous. This is because in some areas the drift aquifer is not thick enough to replace all the missing bedrock units.

Table 2.-Relationship between model layers and hydrogeologic units

Model layer $\begin{aligned} & \text { Confining-unit } \\ & \text { representation }\end{aligned}$

\begin{tabular}{lll}
\hline 5 & Drift \\
\hline $4-5$ & $\begin{array}{l}\text { Decorah-Platteville-Glenwood confining unit, } \\
\text { drift }\end{array}$ \\
\hline 3 & St. Peter aquifer, drift \\
\hline $3-4$ & Basal St. Peter confining unit, drift \\
\hline 2 & Prairie du Chien-Jordan aquifer, drift \\
\hline 1 & St. Lawrence-Franconia confining unit, drift \\
\hline & Ironton-Galesville aquifer, drift \\
\hline & Eau Claire confining unit \\
\hline
\end{tabular}

The hydraulic properties of individual aquifers and confining units were simulated in the preliminary flow model based on information contained in Norvitch and others (1973), Reeder and others (1976), Norvitch and Walton (1979), and the files of the U.S. Geological Survey. The initial flow model was constructed by inputting uniform values of hydraulic parameters for each layer and confining unit (table 3). These values were applied regardless of the interruption of aquifers and confining units by drift-filled bedrock valleys. Unifor $m$ values were used because the objective of the preliminary model was to evaluate the gross properties of the ground-water system and test the sensitivity of individual hydrologic parameters. The areally variable hydraulic properties of the system will be represented in detail in the "final" model of the study area. The final model will be constructed during Phase II of the study, after available hydrologic data have been refined and additional data collected. 


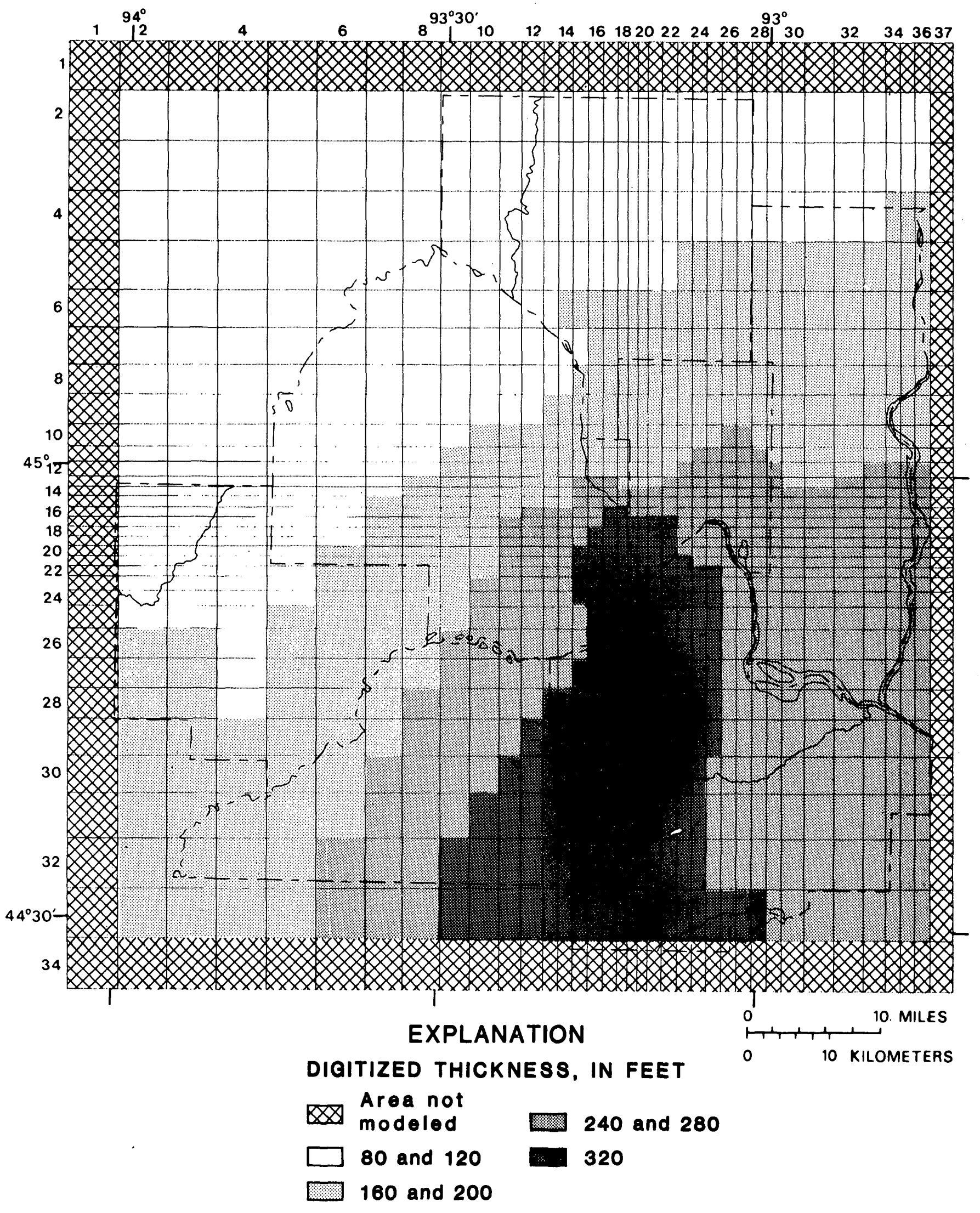

FIgure 6.--ThIckness of the Mount SImon-HInckley aqulfer 


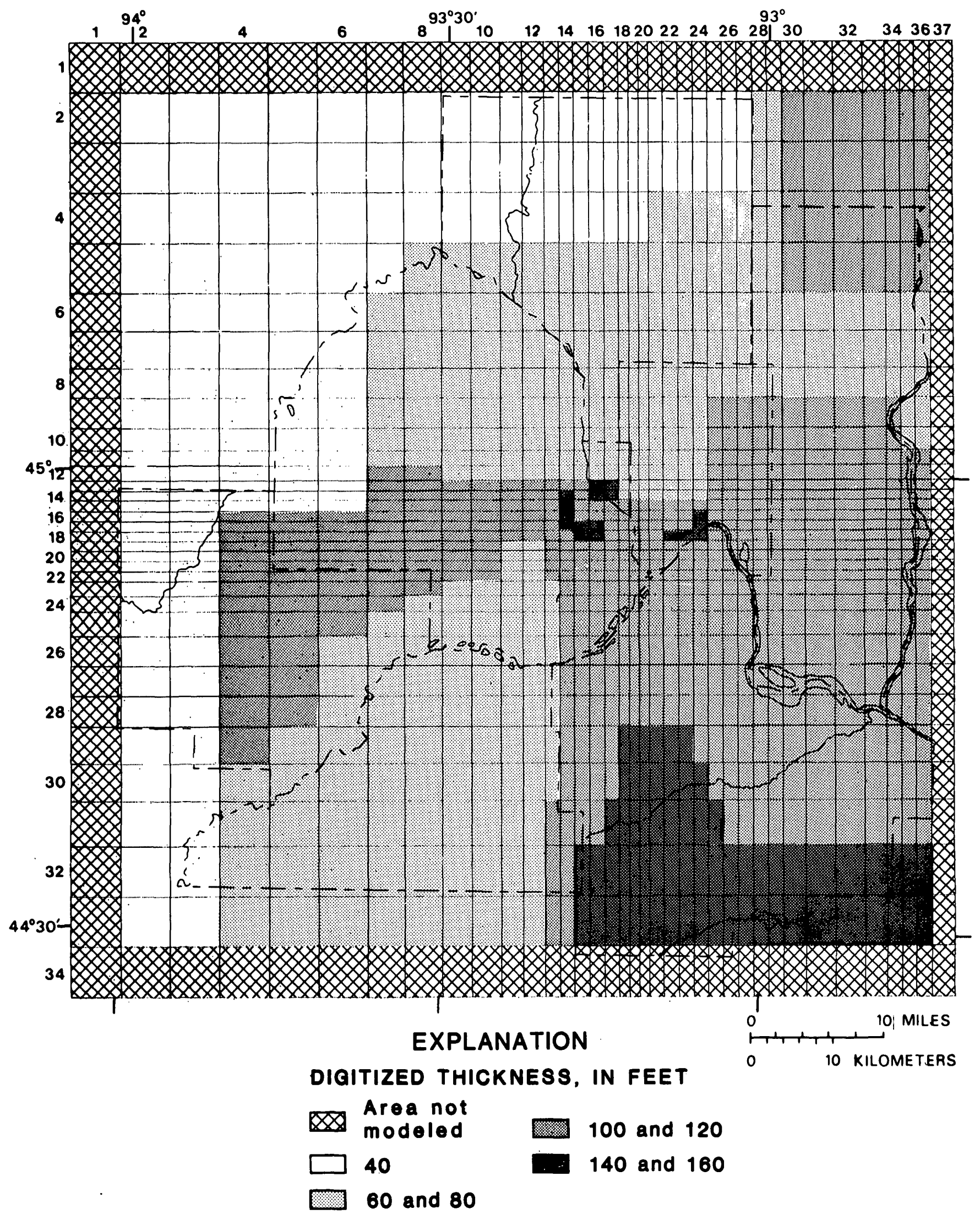

Flgure 6.--Thickness of the Eau Clalre confining unit 


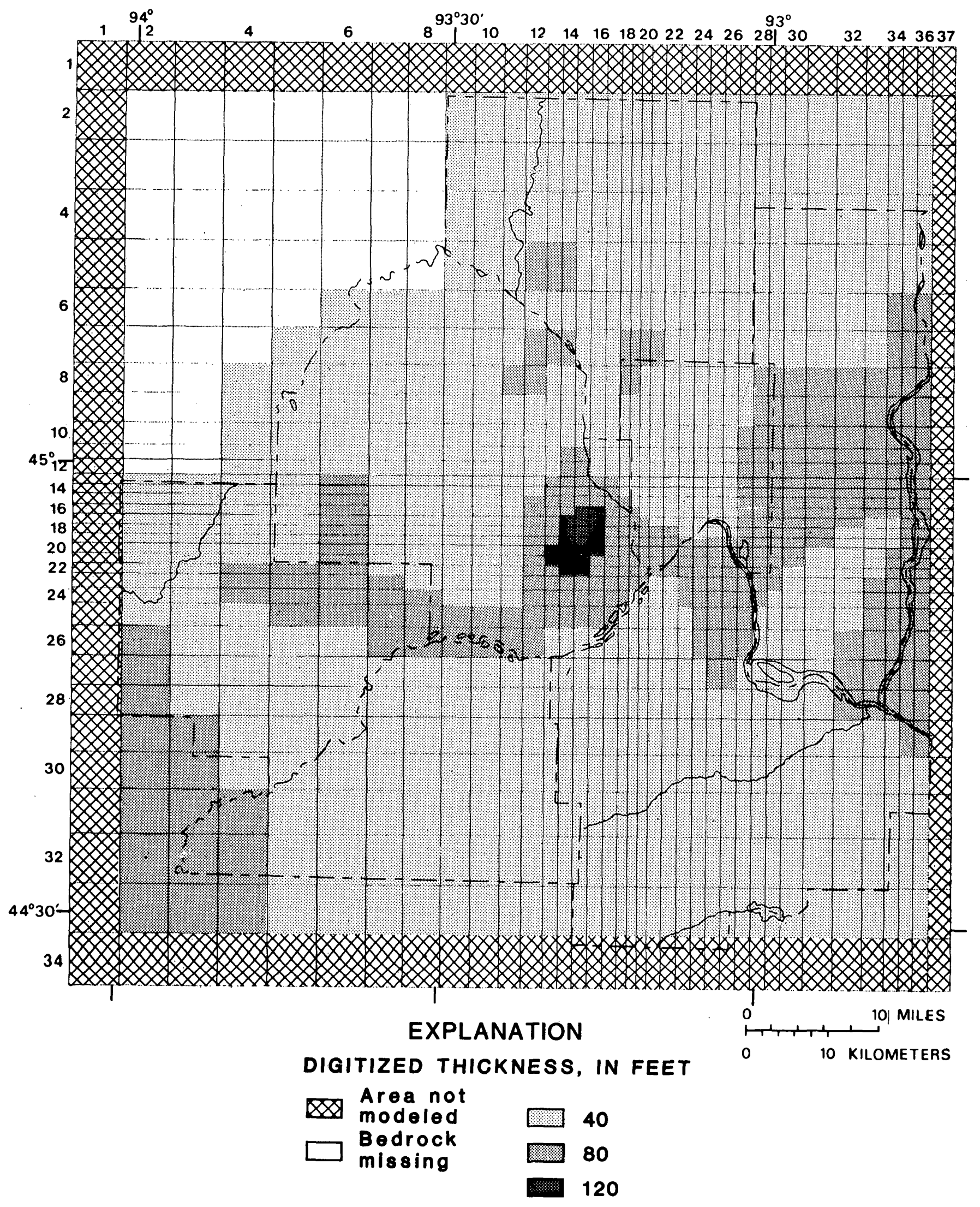

Flgure 7.--Thlckness of the Ironton-Galesville aqulfer 


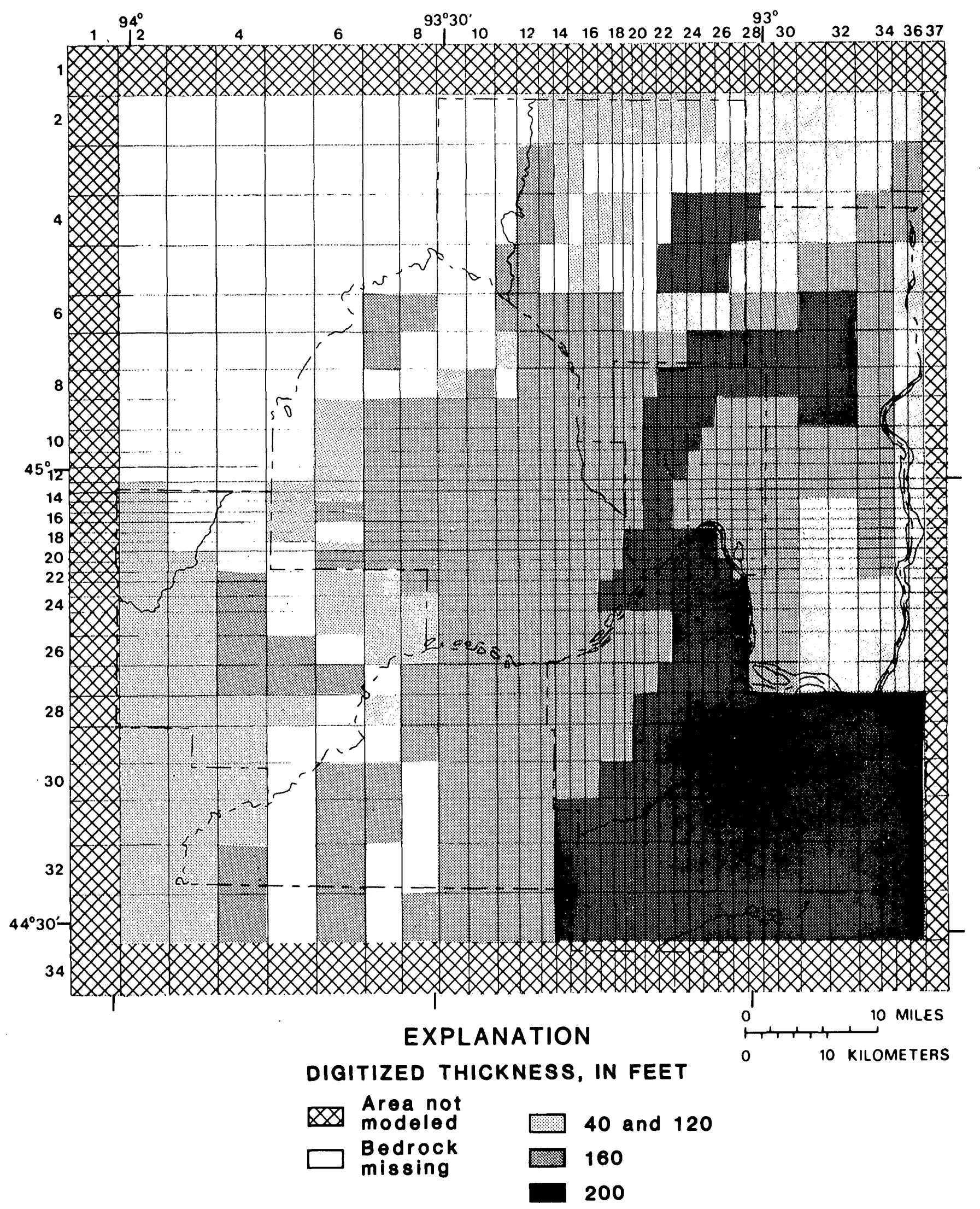

Flgure 8.--Thlckness of the St. Lawrence-Franconla confining unit 


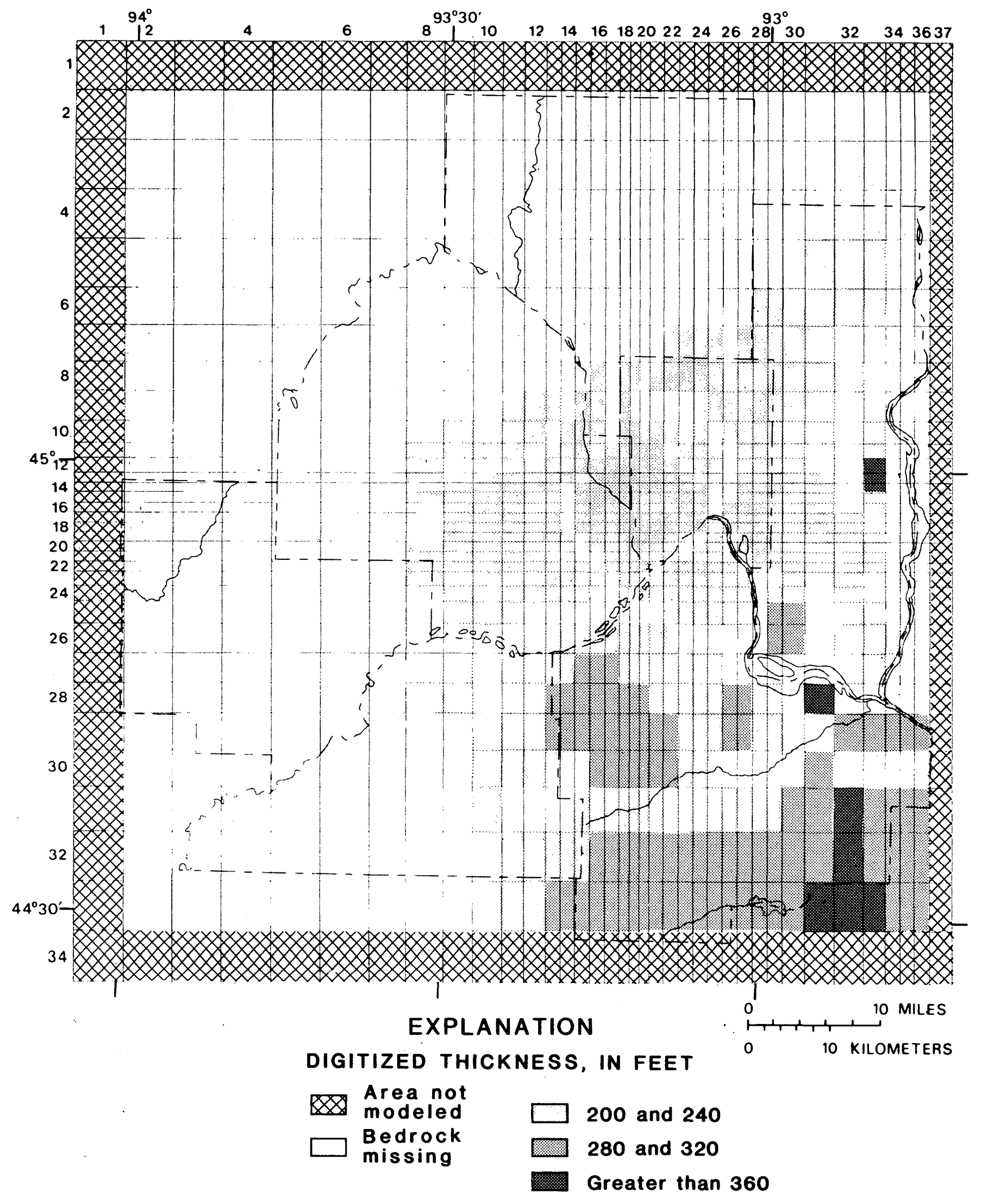

Figure 9.--Thickness of the Prairie du Chien-Jordan aquifer 


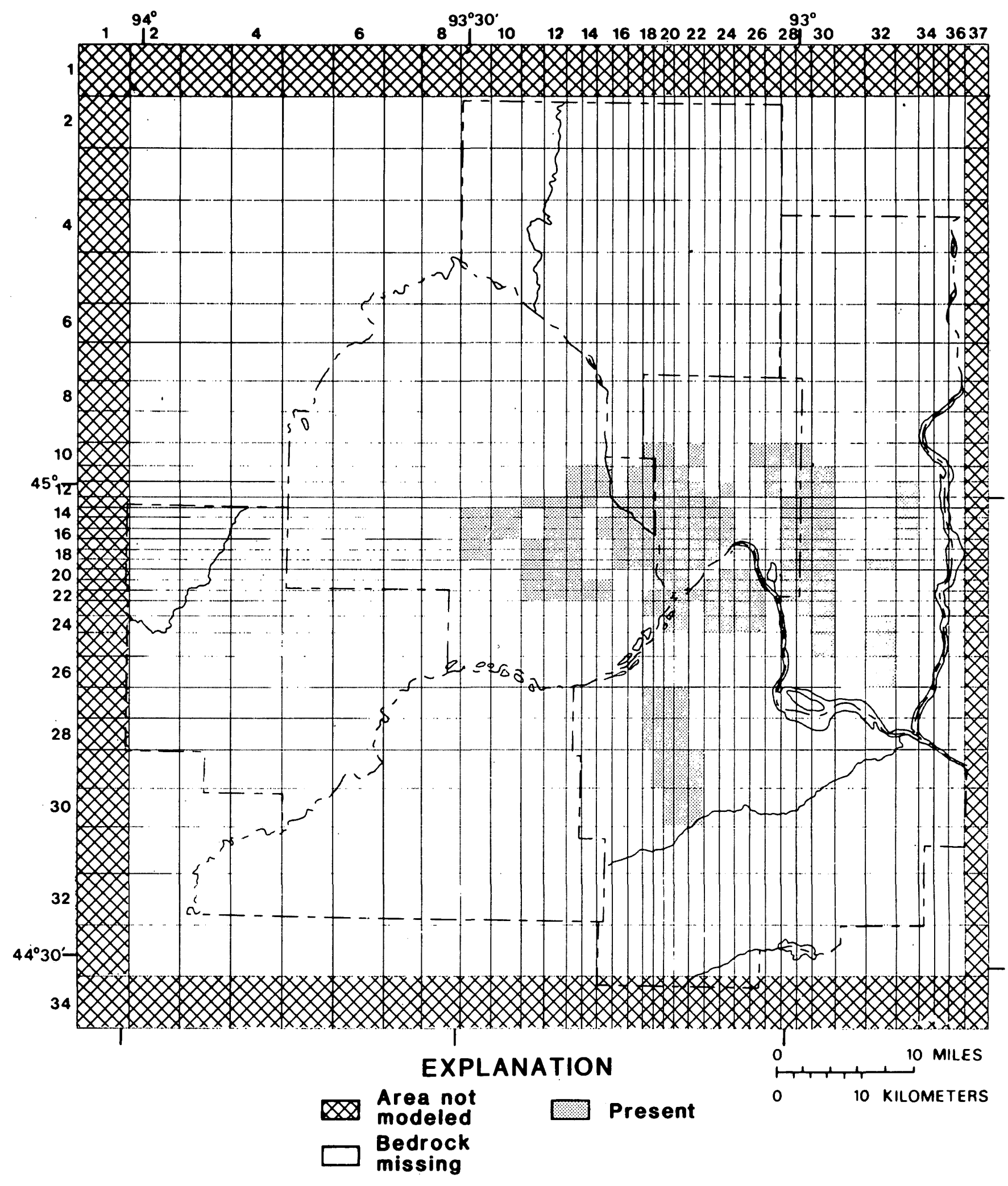

Flgure 10.--Areal extent of basal St. Peter confining unit 


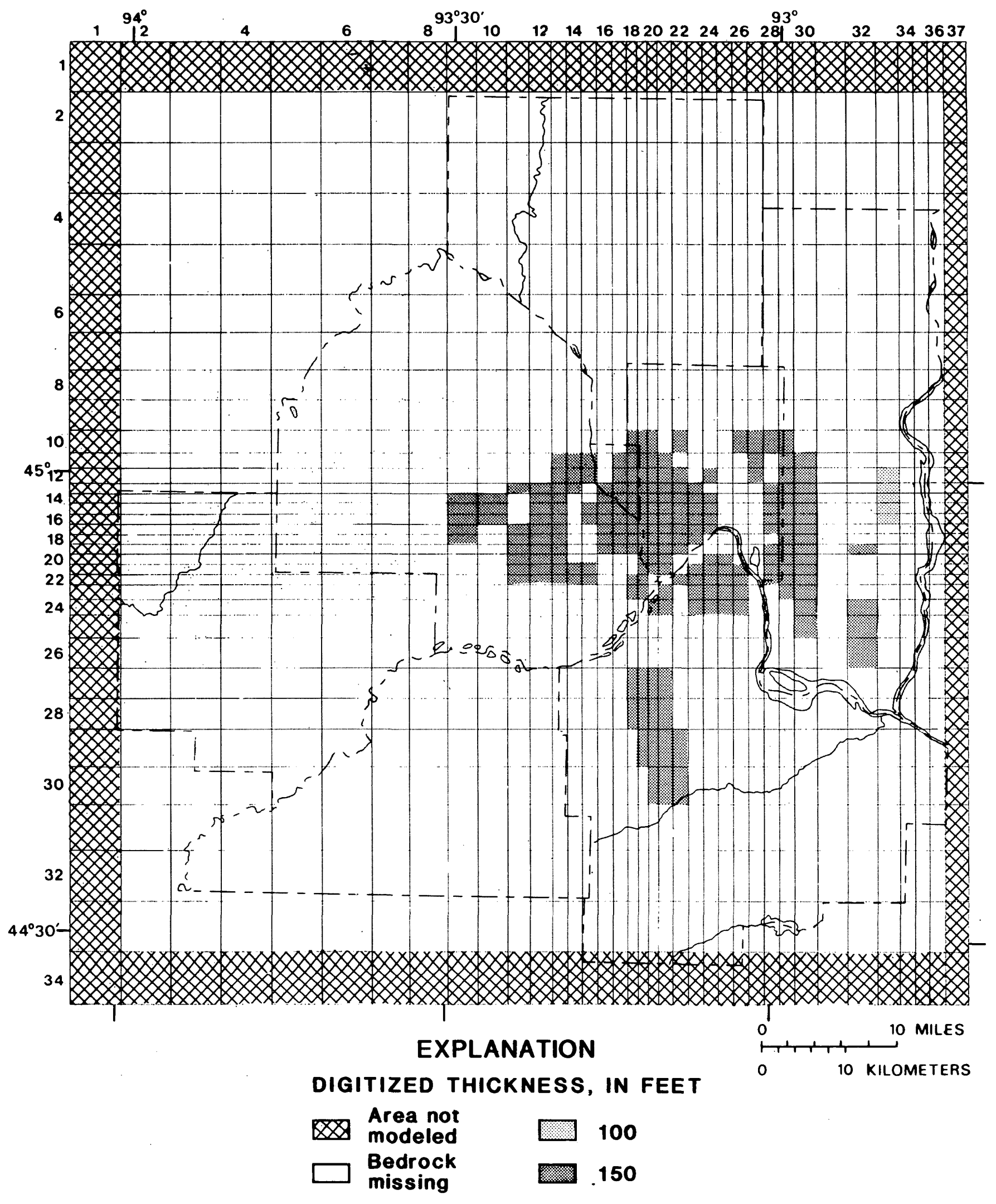

Figure 11.--Thickness of St. Peter aquifer 


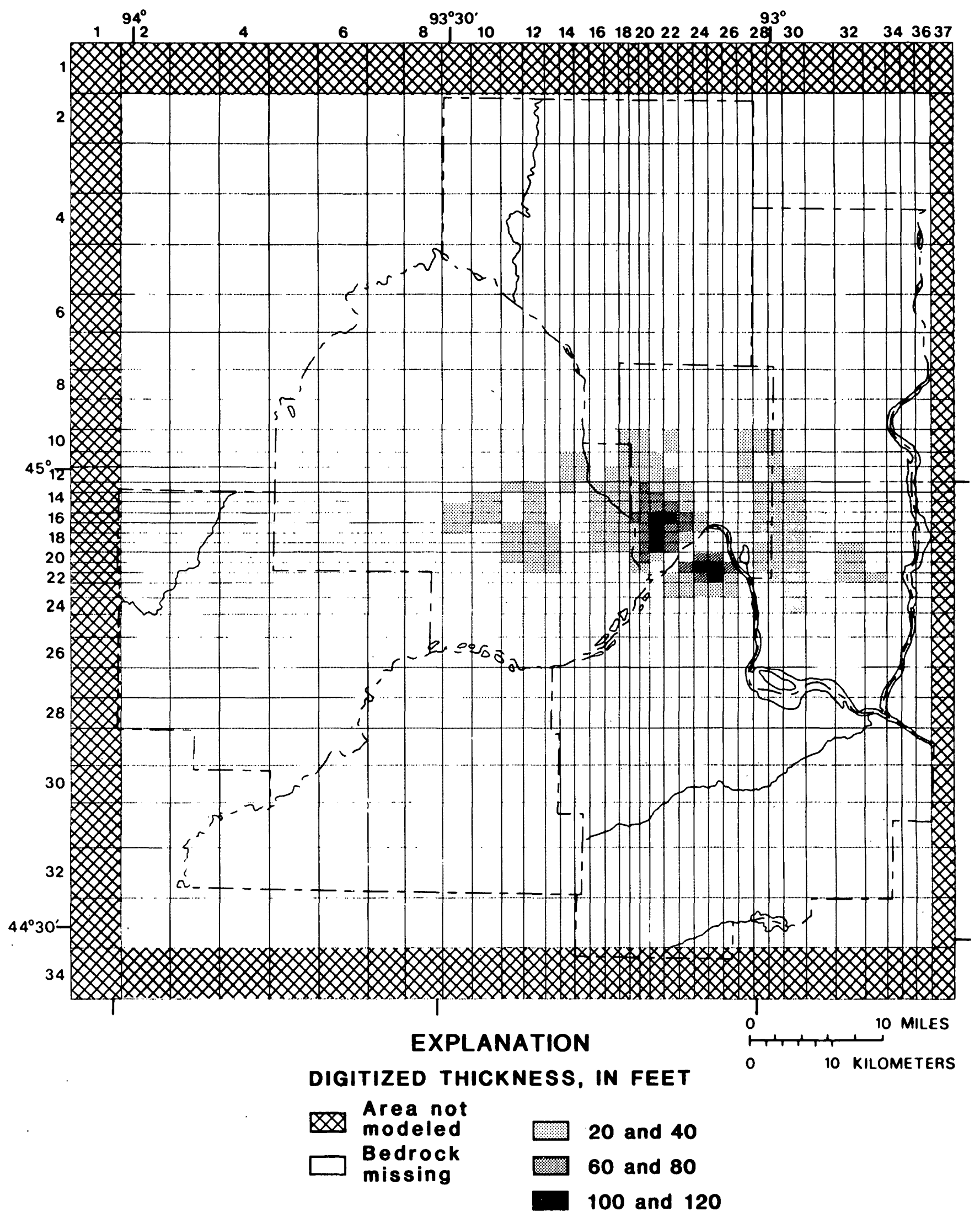

Figure 12.--Thickness of the Decorah-Platteville-Glenwood confining unit 


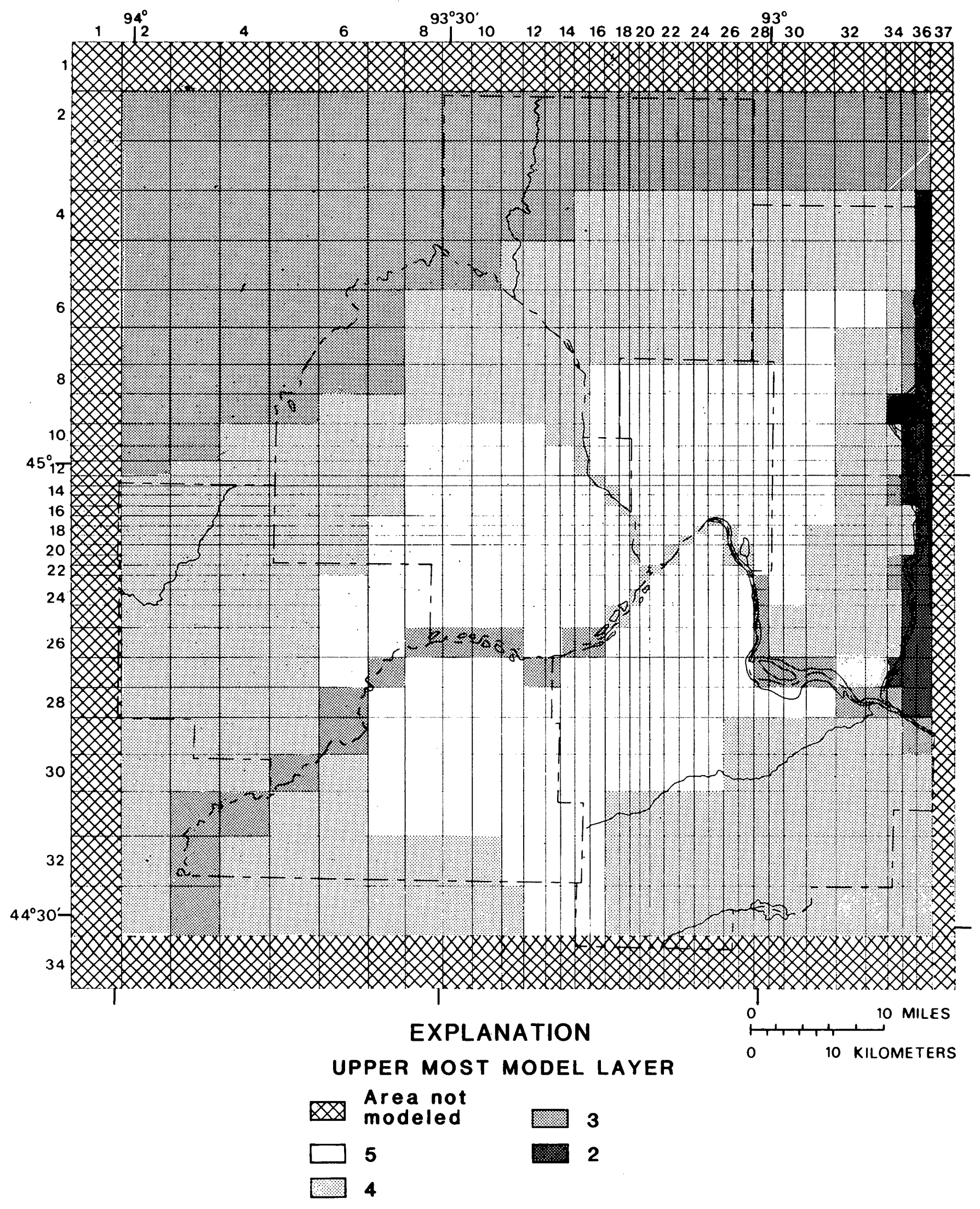

Figure 13.--Uppermost model layer at each model grid block 
Table 3.-Values of hydraulic parameters used in preliminary-model steady-state simulations

\begin{tabular}{cccc}
\hline Model layer & $\begin{array}{c}\text { Confining-unit } \\
\text { representation }\end{array}$ & $\begin{array}{c}\text { Transmissivity } \\
\left(\mathrm{ft}^{2} / \mathrm{d}\right)\end{array}$ & $\begin{array}{c}\text { Leakance } \\
\text { coefficient } \\
{[(\mathrm{ft} / \mathrm{d}) / \mathrm{ft}]}\end{array}$ \\
\hline 5 & $4-5$ & 5000 & $0.5 \times 10^{-5}$ \\
4 & $3-4$ & 6000 & $2 \times 10^{-5}$ \\
3 & $2-3$ & 12,000 & $1 \times 10^{-5}$ \\
1 & $1-2$ & 50 & $2 \times 10^{-5}$ \\
\hline
\end{tabular}

\section{Boundary Conditions and Areal Recharge}

Three types of head-dependent flux boundaries are included in the preliminary model. These are (1) river-aquifer leakage, (2) lateral flow across the edge of the model grid, and (3) spring seepage along the edges of the Mississippi, Minnesota, and St. Croix River valleys. The locations of these boundaries are shown in figures 14 through 18. In the digital model, flow is simulated in either direction across the river-aquifer boundary. Flow is calculated using the difference in head between the river stage (fixed during the period of simulation) and the model-computed aquifer head. Similarly, flow is simulated in either direction across the boundaries of the model grid. The flow rate is determined on the basis of the head difference between the computed head at a node and an external head that remains constant during the period of simulation. The spring-seepage boundary only allows flow to be simulated out of the aquifer. The gradient used by the model to calculate the rate of flow from springs is the difference between the computed head in any grid block containing a spring and the estimated altitude of spring discharge. Discharge was assumed to occur at the aquifer base where it crops out along the river valleys.

An average difference between precipitation and evapotranspiration rates of approximately 6.5 inches per year was calculated by Norvitch and others (1973, p. 65-66). This water recharges the surficial deposits and is discharged to nearby streams, rivers, lakes, and wells, or moves downward to recharge underlying bedrock aquifers. Because not all natural discharge boundaries of the aquifers are explicitly included in the simulation model, the areal recharge rate appropriate for the model must be less than 6.5 inches per year. A rate of 3.5 inches per year was applied to each of the grid blocks shown on figure 13. This areal recharge value will continue to be evaluated during the second phase of the study. 


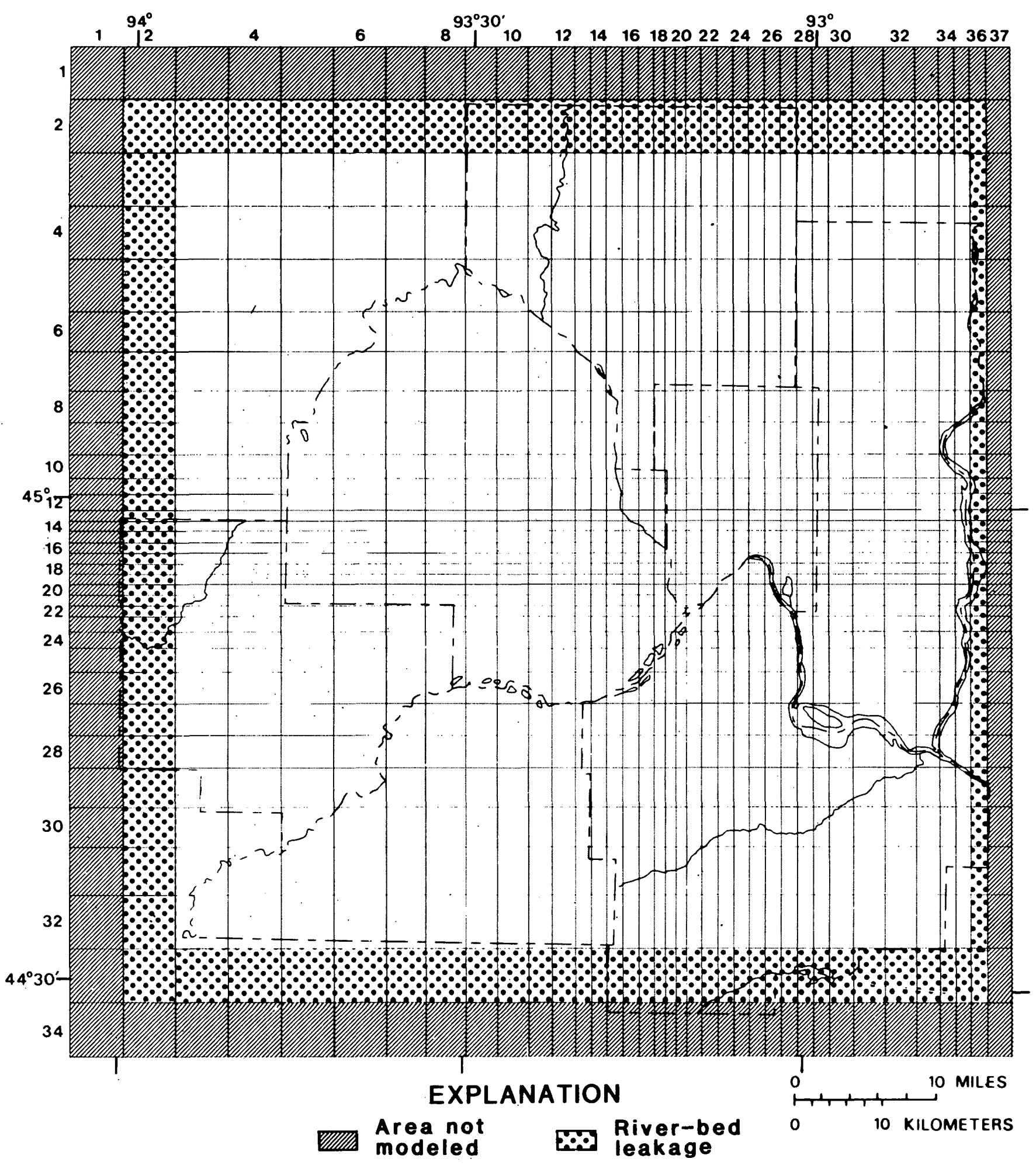

Figure 14.--Location of head-dependent flux boundaries, model layer 1 (Mount Simon-Hinckley aquifer) 


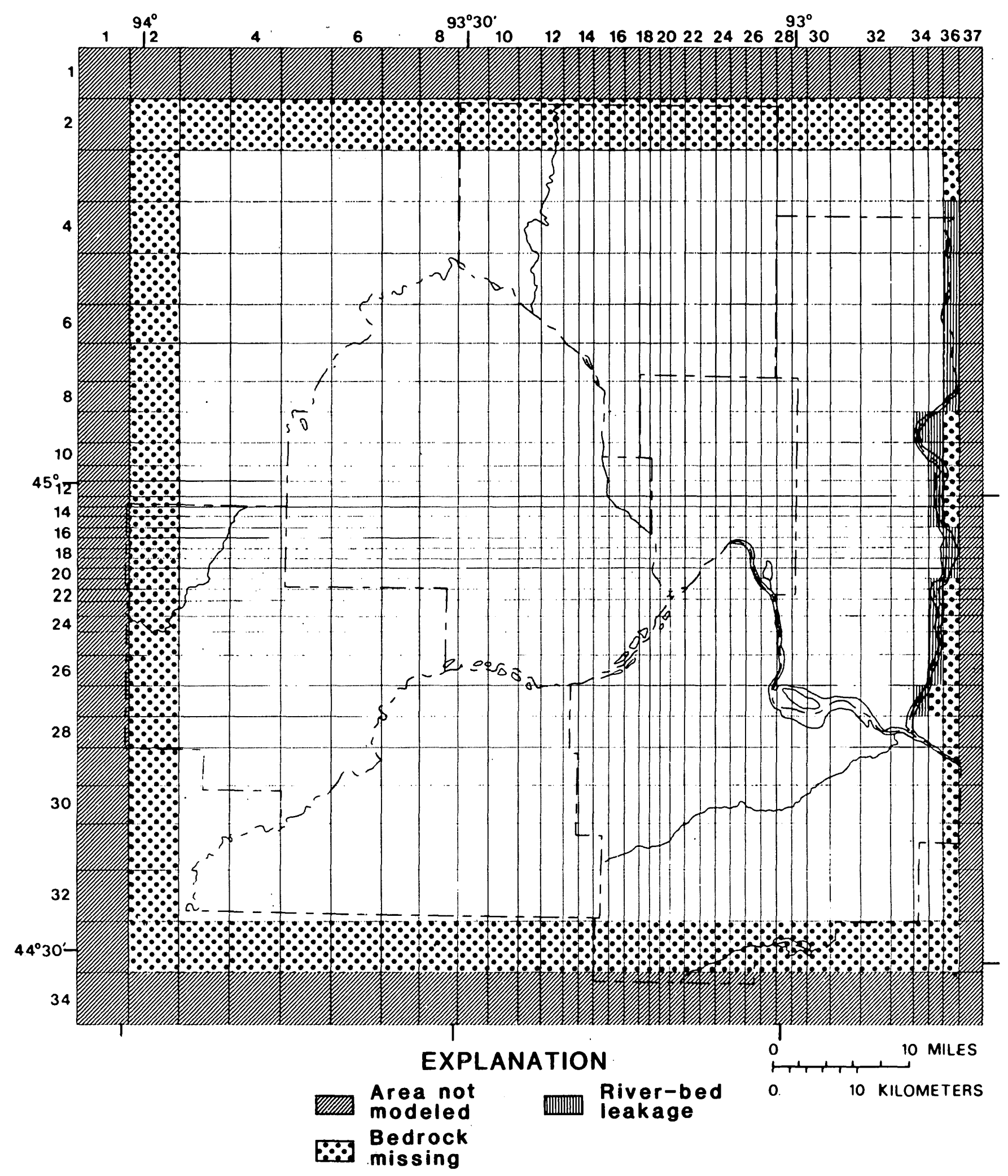

Figure 15.--Location of head-dependent flux boundaries, model layer 2 (Ironton-Galesville aquifer) 


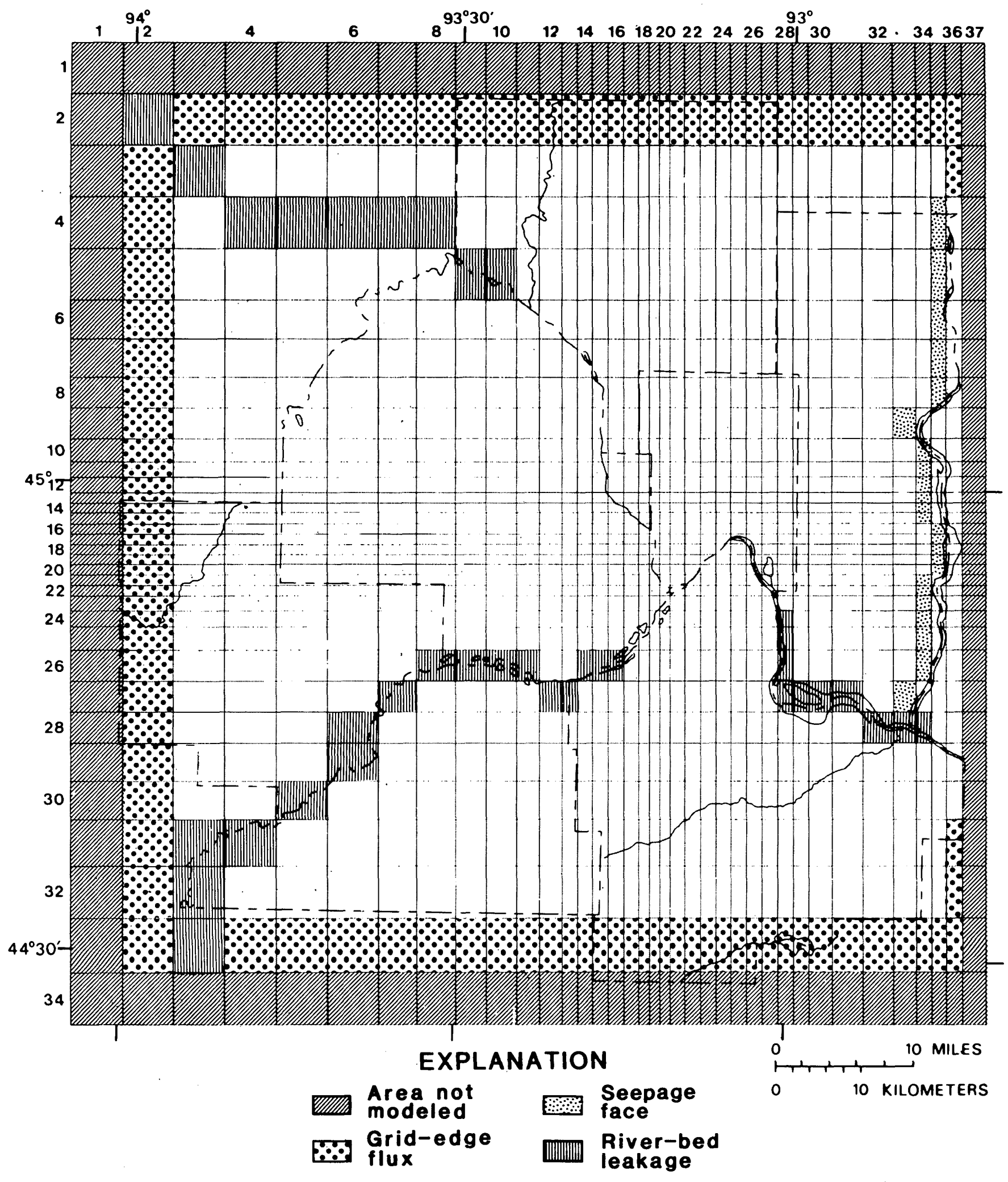

Figure 16.--Location of head-dependent flux boundaries, model layer 3 (Prairie du Chien-Jordan aquifer) 


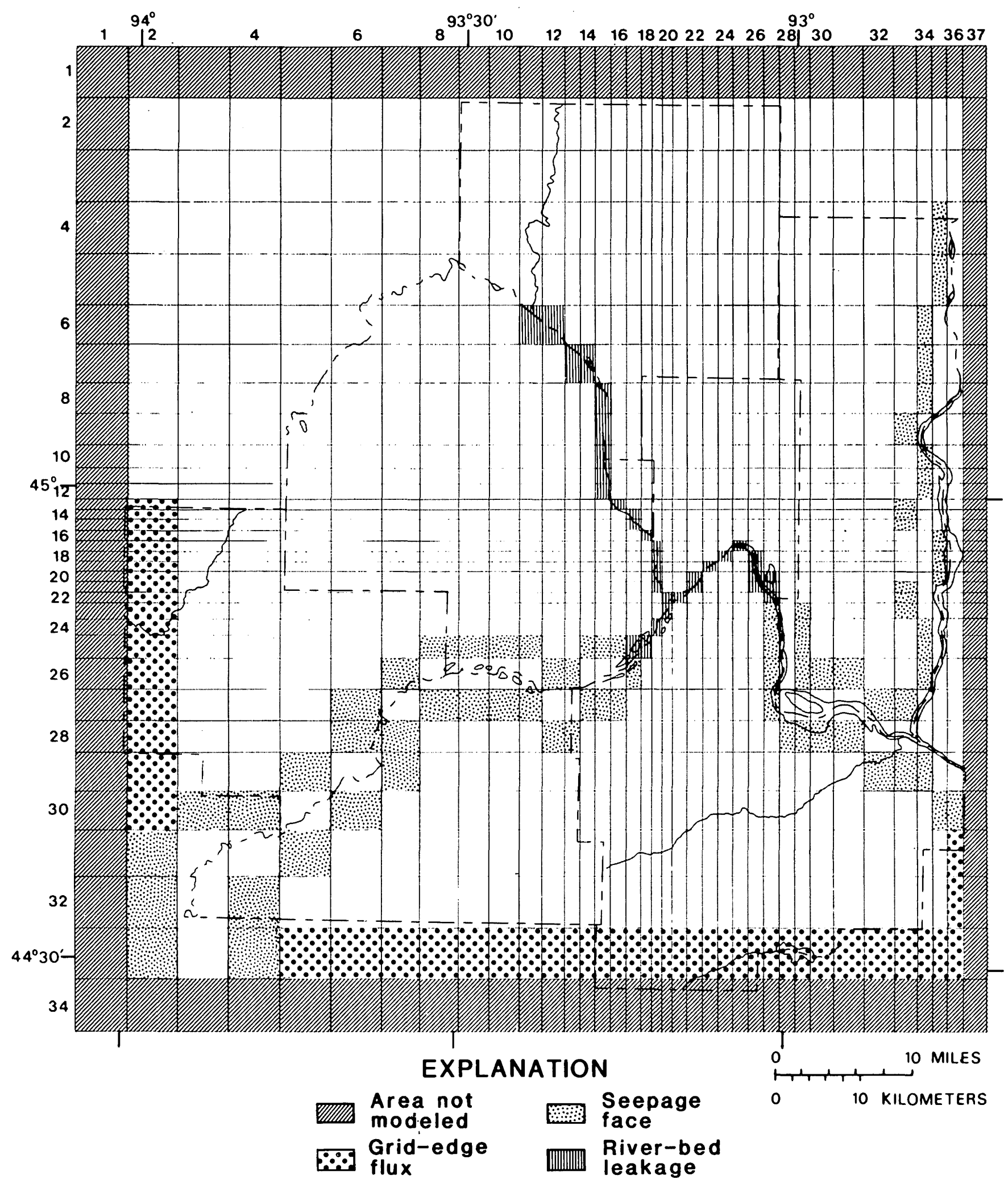

Figure 17.--Location of head-dependent flux boundaries, model layer 4 (St. Peter aquifer) 


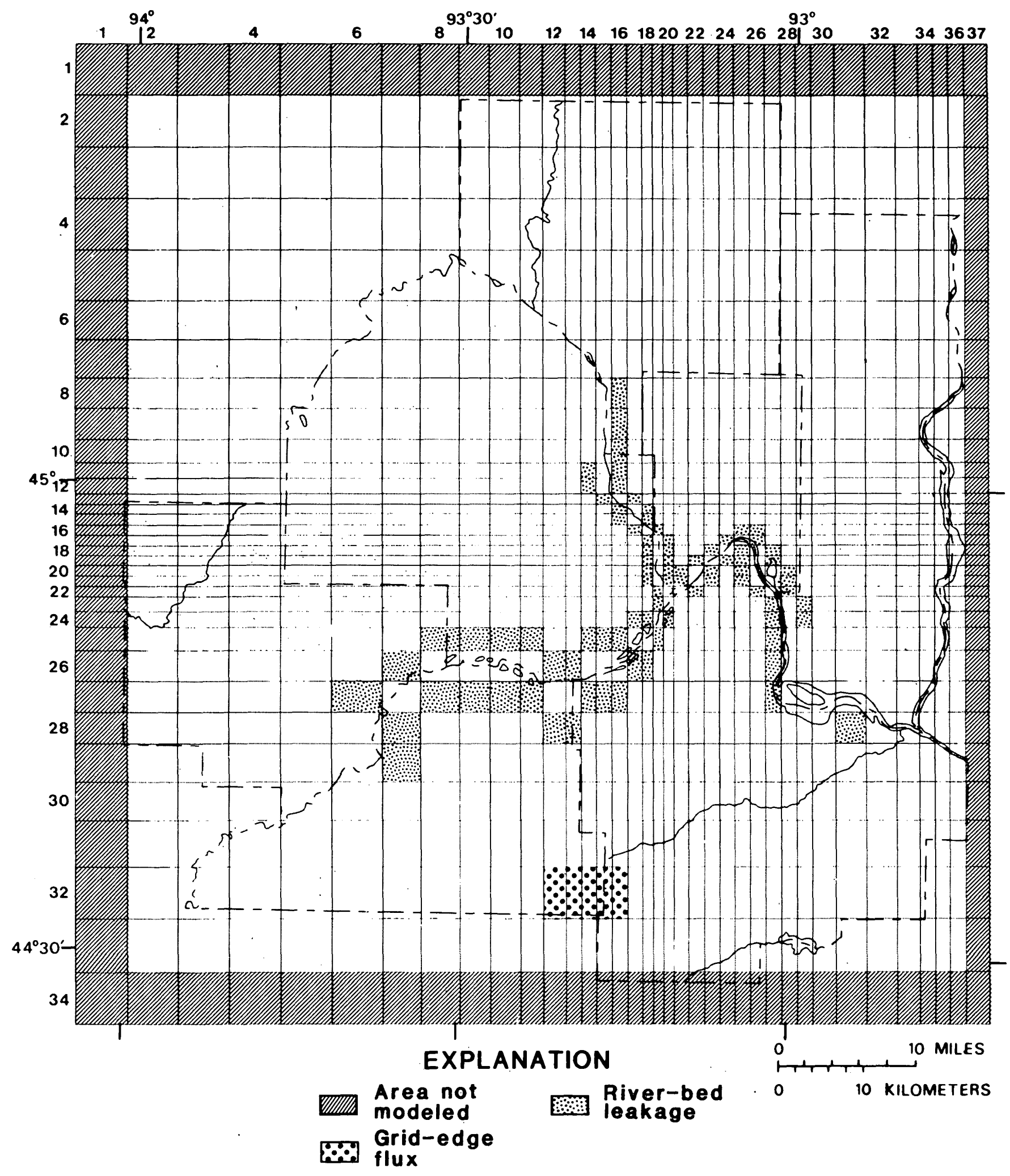

Figure 18.--Location of head-dependent flux boundaries, model layer 5 (drift) 


\section{Observed Potentiometric Levels}

Potentiometric-level information available to aid evaluation of the preliminary flow model includes measurements from 74 wells between 1880 and 1890 , and 472 wells between 1965 and the present (1980). Fourteen wells measured between 1880-90 are completed in the Mount Simon-Hinckley aquifer and 60 are in the Prairie du ChienJordan aquifer. There are no measurements available for the Ironton-Galesville, St. Peter, and drift aquifers for this period. Of the 472 wells monitored since 1965, approximately 50 have been measured regularly (approximately monthly) and the remainder periodically. The greatest number of measurements were made during four periods: winter (February) 1971, summer (August) 1971, summer (August) 1977, and winter (February) 1978. However, the same wells were not necessarily measured in each period. The same 208 wells were measured in all four periods, 50 were measured in three of the four periods, 165 in two, and 49 in one. Thirty wells are in the Mount Simon-Hinckley aquifer, 339 in the Prairie du Chien-Jordan aquifer, 65 in the St. Peter aquifer, and the remainder in the drift aquifer. None of the wells are in the Ironton-Galesville aquifer.

To evaluate the preliminary model, an average potentiometric level for 1971-78 was calculated for all wells measured at least periodically since 1971. A weighted average representing 1971-78 potentiometric level was calculated for each of the 50 wells measured regularly since 1965. For each of these wells a departure from the average potentiometric level was calculated for each of the four periods mentioned previously. These departures from average values, which were interpreted to represent the natural short-term imbalance between recharge and discharge, were used to extrapolate each of the measured potentiometric levels at the remaining wells to an average potentiometric level. An arithmetic average for the extrapolated potentiornetric levels was then determined for each well. These average potentiometric levels will be referred to hereafter as observed potentiometric levels.

\section{Ground-Water Withdrawal}

Information on ground-water withdrawal was extracted primarily from the files of the Minnesota Department of Natural Resources, U.S. Geological Survey, Minnesota Geological Survey, and Minnesota Department of Health. This information was supplemented by an inventory of Ramsey County water users.

Most of the ground-water-withdrawal data needed for the preliminary model were obtained from the files of the Minnesota Department of Natural Resources. Although these files contain the most complete records for the 1970 's, the information was not adequate for this study because aquifer designations and well locations were missing or inaccurate. It was also known that not all ground-water withdrawals were being reported. An inventory of ground-water users in Ramsey County indicated that the available records represented less than 90 percent of the actual ground-water withdrawals for 1976. Time constraints for the first phase of this study precluded an inventory of the remaining counties, but it is believed that the discrepancy between reported and actual pumpage is about the same for Hennepin County. For the more rural counties, where most withdrawals are for irrigation and wells have been drilled recently, the discrepancy between reported and actual pumpage is probably less than 10 percent. The water-use inventory will continue during the second phase of this project and will include the remaining six counties in the metropolitan area. 
For 1971-77, an average withdrawal rate was calculated for more than 750 wells. The rate was calculated as the arithmetic average of pumpage for 1970 and 1976, because these two years were the only ones for which water-use data were readily available or easily estimated. For some wells the estimated withdrawal rate may be grossly inaccura te because of a lack of complete information. However, during the second phase of this project an intensive effort will be made to tabulate water-use information for 1971-79 so that it can be more accurately represented in the final model simulations. Average withdrawal rates for 1971-77 are summarized in table 4. The magnitude and distribution of withdrawals from the Mount Simon-Hinckley and Prairie du Chien-Jordan aquifers are shown in figures 19 and 20, respectively.

Table 4.-Average ground-water withdrawals, 1971-77

\begin{tabular}{|c|c|c|c|c|}
\hline \multirow[b]{2}{*}{$\begin{array}{l}\text { Model } \\
\text { layer }\end{array}$} & \multirow[b]{2}{*}{ Principal aquifer } & \multicolumn{3}{|c|}{ Withdra wal rate } \\
\hline & & $\begin{array}{l}\text { (Million } \\
\text { gallons } \\
\text { per year }\end{array}$ & $\begin{array}{l}\text { (Thousand } \\
\text { cubic feet } \\
\text { per day) }\end{array}$ & $\begin{array}{l}\text { (Million } \\
\text { gallons } \\
\text { per day) }\end{array}$ \\
\hline \multirow{6}{*}{$\begin{array}{l}5 \\
4 \\
3 \\
2 \\
1\end{array}$} & drift & 1,073 & 393 & 3 \\
\hline & St. Peter & 2,181 & 799 & 6 \\
\hline & Prairie du Chien-Jordan & 46,241 & 16,937 & 127 \\
\hline & Ironton-Galesville* & 4,871 & 1,784 & 13 \\
\hline & Mount Simon-Hinckley & 7,006 & 2,566 & 19 \\
\hline & Totals & 61,372 & 22,479 & 168 \\
\hline
\end{tabular}

* Most are multiaquifer wells also open to either the Prairie du Chien-Jordan or Mount Simon-Hinckley aquifers.

\section{Steady-State Simulations}

To evaluate the preliminary flow model, two steady-state, or equilibrium, simulations were made. The steady-state simulations compute the head distribution for the system where inflow, such as recharge from precipitation or leakage from streams and lakes, is balanced by outflow, such as pumpage or discharge to streams and lakes. The steady-state simulations do not consider the storage properties of the ground-water system and, therefore, are not time dependent. The two simulations represent (1) a period prior to significant ground-water development (approximately 1885), and (2) a period of extensive ground-water development (1971-77). For the 1885 simulation it was assumed that the pre-ground-water development system was in equilibrium and, on the average, recharge was balanced by discharge. For the 1971-77 period, it was assumed that a steady-state simulation using average withdrawal rates and average observed potentiometric levels, although oversimplified, would (1) provide additional information about the behavior of the flow system, (2) allow evaluation of the gross properties of the system, and (3) facilitate the testing of parameter sensitivity. 


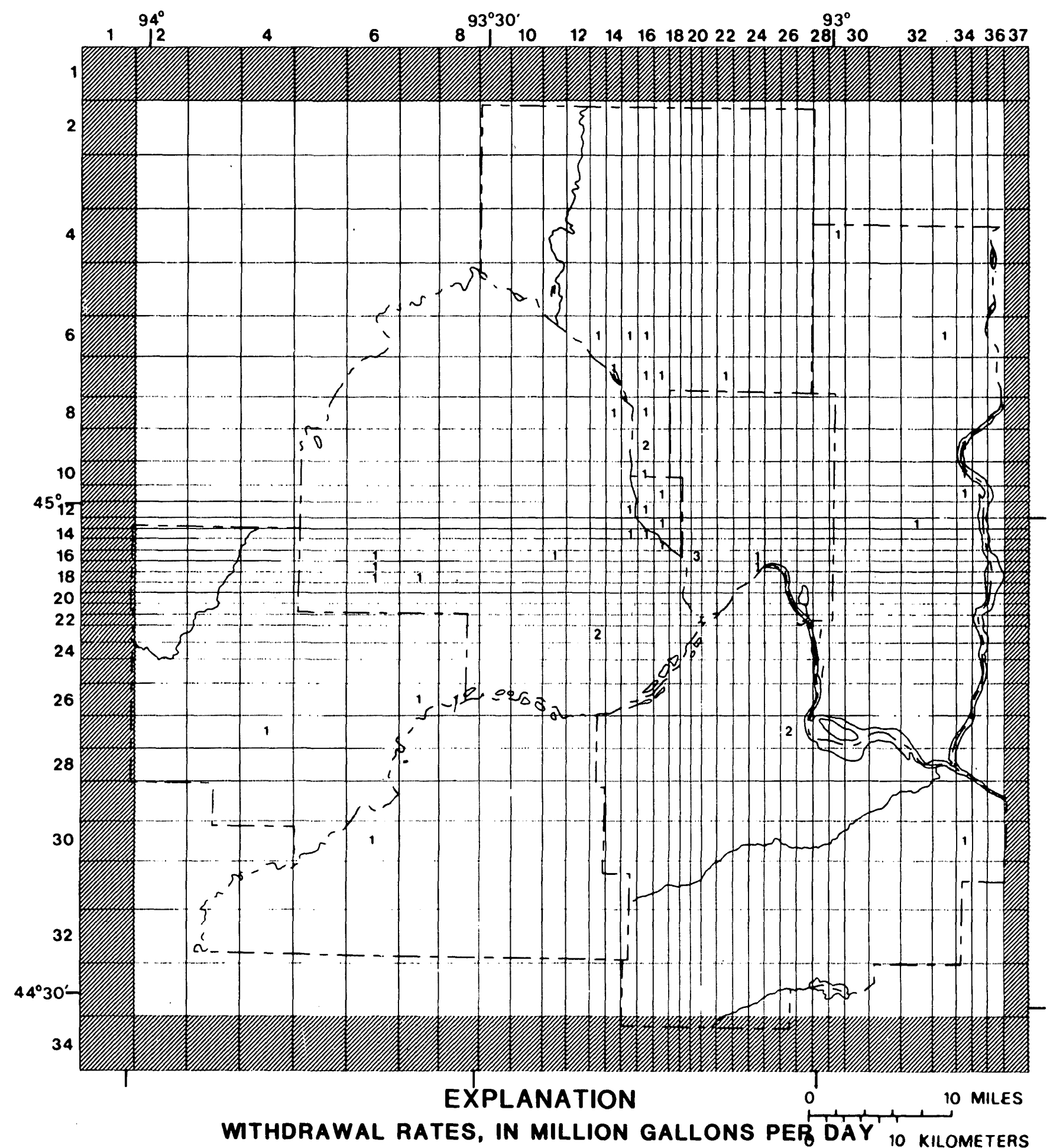

1 Less than $1 \quad 3 \quad 2$ to 4

21 to 2

Figure 19.--Summary of average withdrawal rates for Mount Simon-Hinckley aquifer, $1971-77$ 


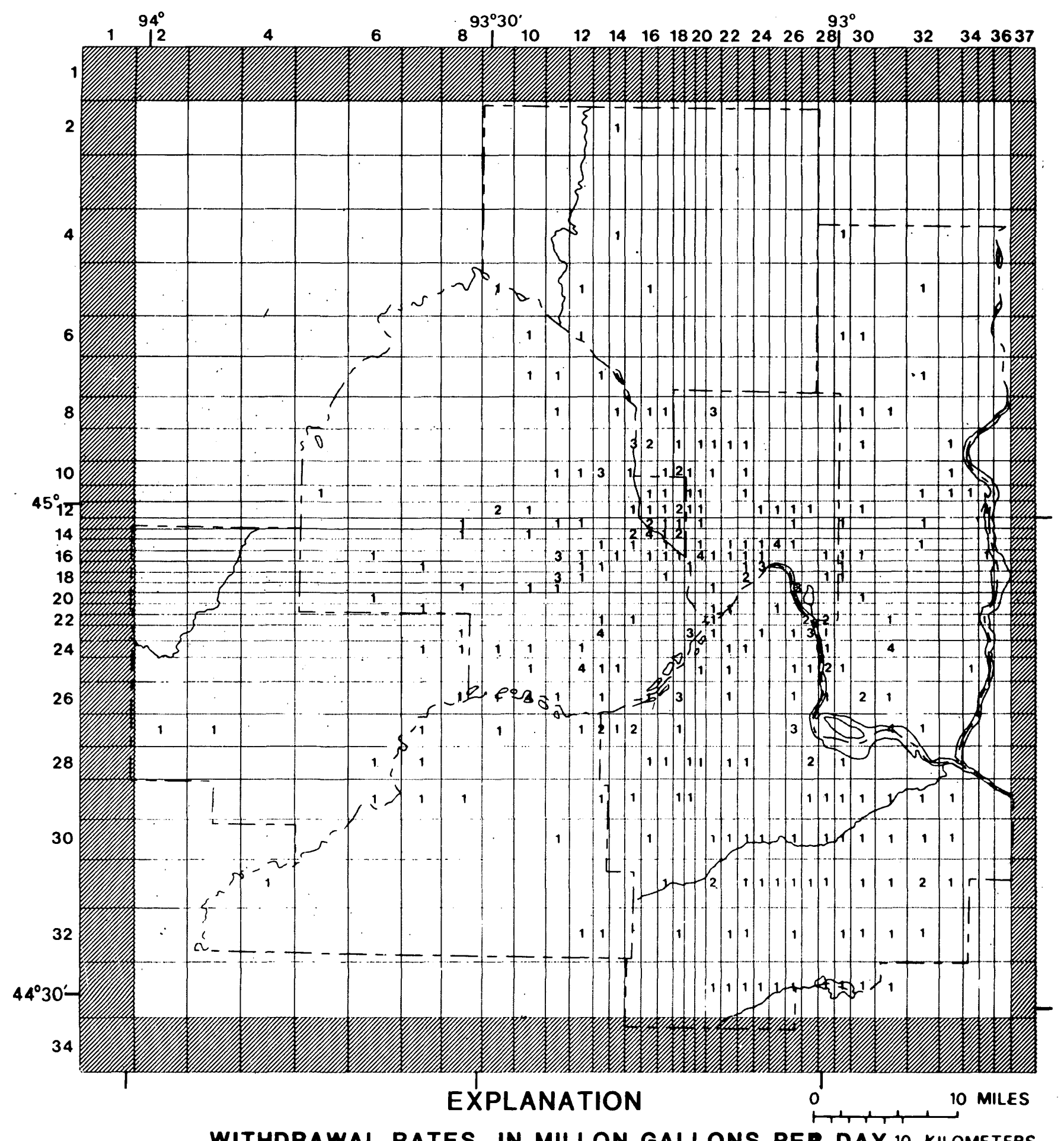

WITHDRAWAL RATES, IN MILLON GALLONS PER DAY 10 KILOMETERS

\begin{tabular}{llll}
\hline & Less than 1 & 3 & 2 to 4 \\
2 & 1 to 2 & 4 & Greater than 4 \\
\hline
\end{tabular}

Figure 20.--Summary of average withdrawal rates for Prairie du Chien-Jordan aquifer, $1971-77$ 
The 1971-77 period was chosen because it is the time for which the greatest amount of potentiometric-level and withdrawal information is available. Water-level measurements made between 1971 and early 1978 indicate no significant long-term change in potentiometric levels for the Prairie du Chien-Jordan, St. Peter, and drift aquifers. However, potentiometric levels in the Mount Simon-Hinckley aquifer have risen continually during the period. This rise is probably because of decreases in withdrawals from the aquifer. However, data presently available are not sufficient to test this hypothesis with the preliminary model. Changes in withdrawal rates through this period will be documented and analyzed in much greater detail prior to construction and testing of the final flow model, at which time some time-dependent simulations may be possible.

\section{Evaluation of Model Performance}

Performance of the preliminary model was evaluated by comparing the difference between model-computed and observed potentiometric levels. In this report, this difference is referred to as a "residual." The uncertainties involved in this comparison are (1) model approximations do not always consider localized detailed variations in aquifer properties that can affect measured water levels, (2) an observed potentiometric level may not represent the average head over the grid block, which the model computes, (3) observed potentiometric levels may not represent the average water level for the period of interest because of the short-term effects of pumping and natural seasonal waterlevel changes, (4) observed potentiometric levels may be affected by nearby pumping that may not be accurately simulated in the model, (5) measuring-point altitudes may be in error, and (6) potentiometric levels measured in a well that does not penetrate the full aquifer thickness or that penetrates more than one aquifer may be different from those measured in a well that fully penetrates a single aquifer. These sources of uncertainty cannot always be quantified, but should be considered when evaluating differences between observed and model-computed potentiometric levels.

The residuals for the two preliminary simulations are shown in figures 21-26. The discrepancies between model-computed and observed potentiometric levels identify parts of the simulation model that have the greatest need for refinement. This refinement will include evaluation of hydraulic parameters, boundary conditions, ground-water withdrawals, and observed potentiometric, levels. In general, positive residuals indicate that the local model-computed potentiometric level is greater than the observed, and negative residuals indicate that the local model-computed potentiometric level is less than the observed.

Considering that the preliminary model is very generalized with respect to hydraulic parameter values, the results of the 1885 simulations are reasonably good (figs. 21 and 22). The areas most in need of evaluation and improvement are (1) downtown St. Paul where the model-computed potentiometric levels for the Mount Simon-Hinckley and Prairie du Chien-Jordan aquifers are generally high, and (2) northeastern Ramsey County where the model-computed potentiometric levels are generally low for these two aquifers. Lack of potentiometric-level information for the Ironton-Galesville, St. Peter, and drift aquifers precludes use of the 1885 simulation to evaluate these parts of the preliminary model. 


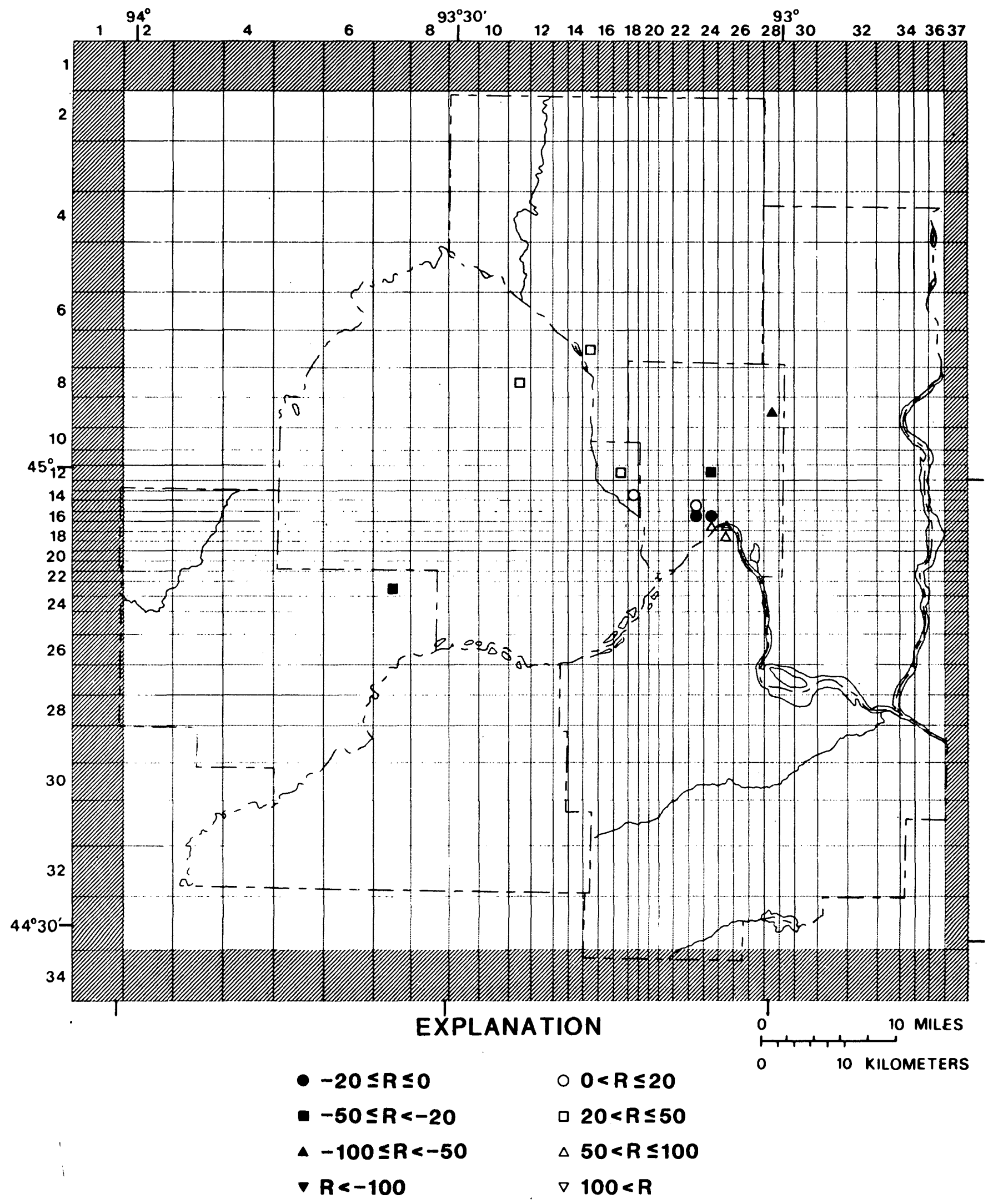

Figure 21.--Summary of residuals for 1885 simulation, layer 1 (Mount Simon-Hinckley aquifer] 


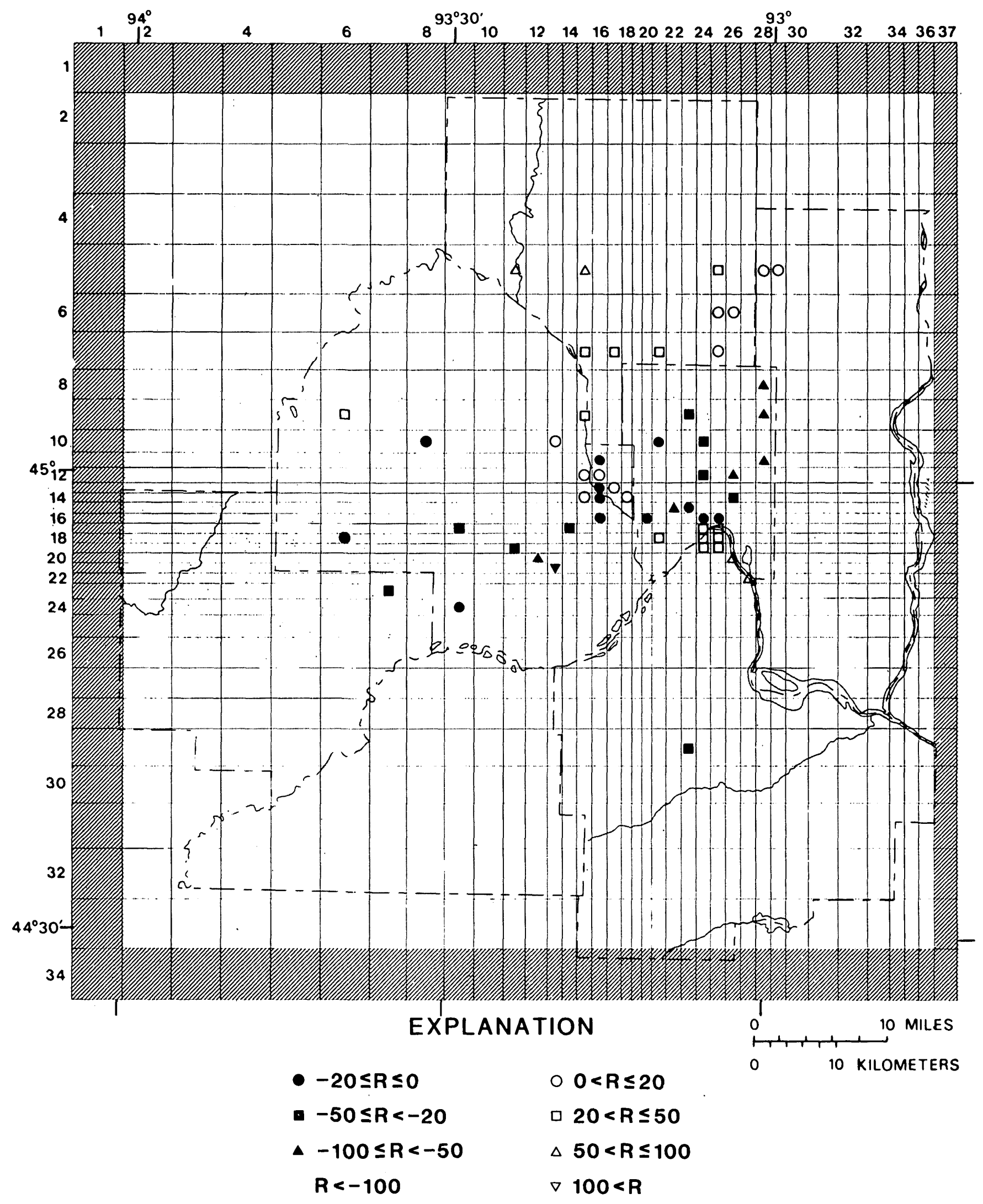

Figure 22.--Summary of residuals for 1885 simulation, layer 3 (Prairie du Chien-Jordan aquifer] 


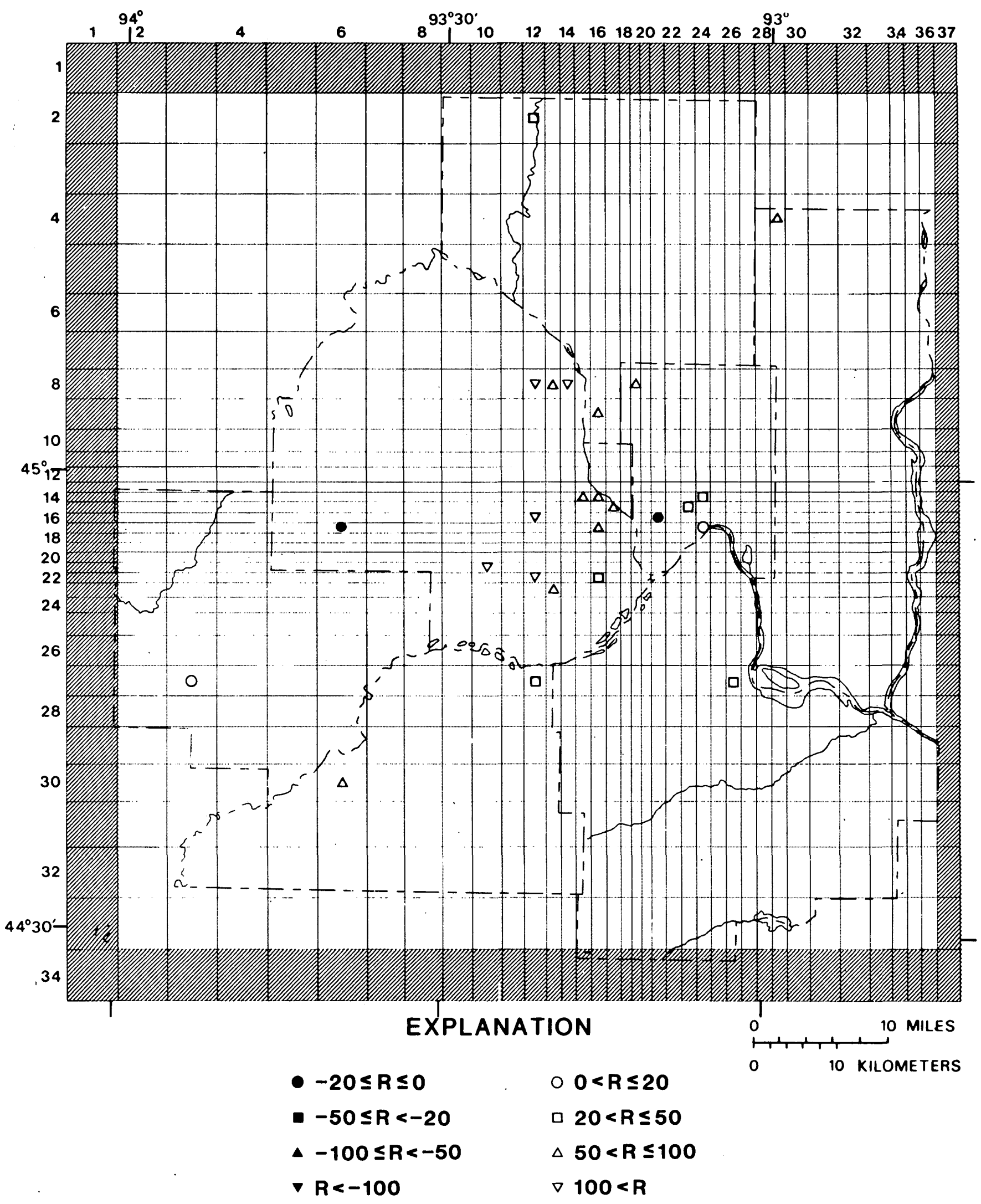

Figure 23.--Summary of residuals for 1971-77 simulation, layer 1 (Mount Simon-Hinckley aquiferJ 


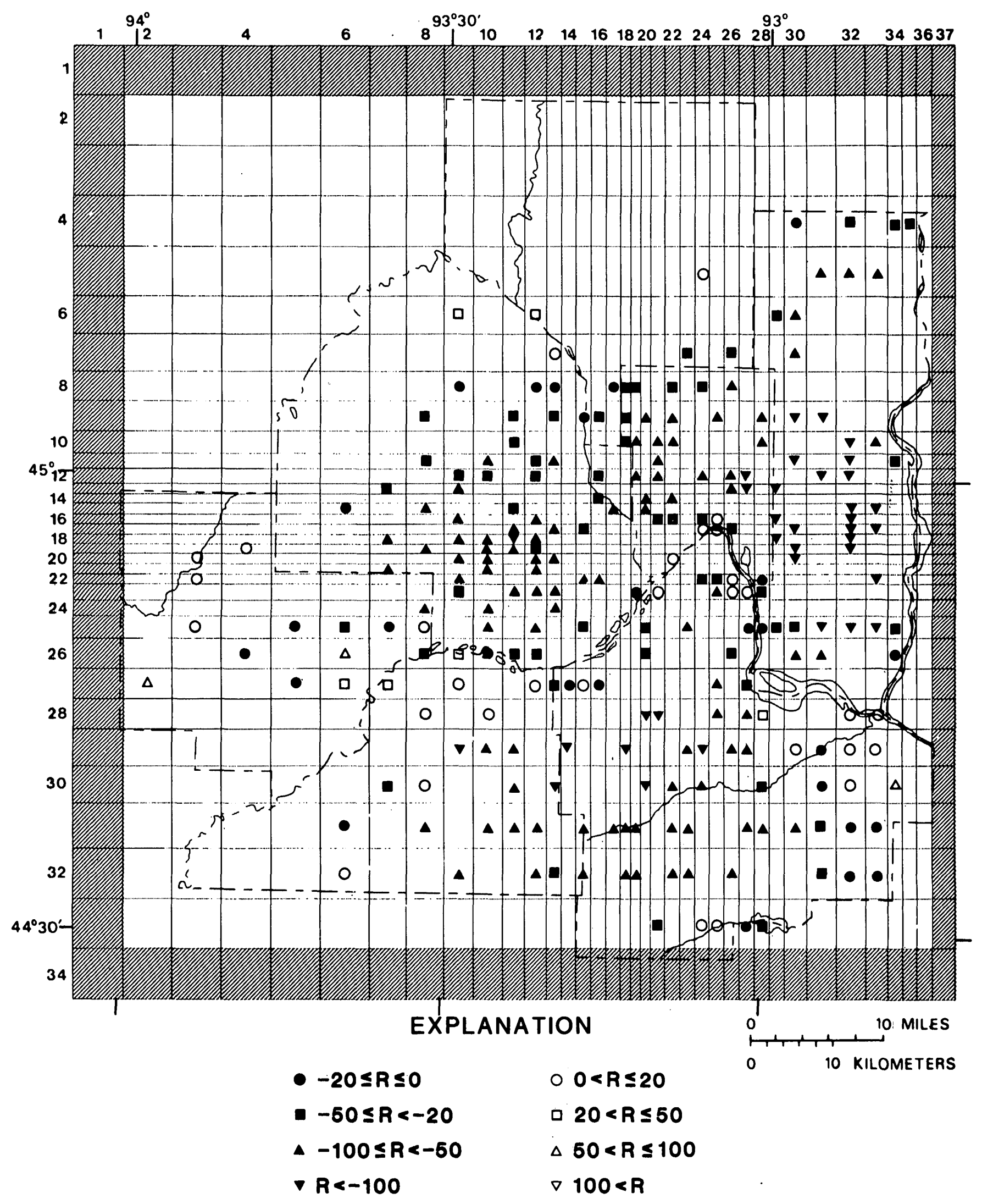

Flgure 24.--Summary of reslduals for 1971-77 simulatlon, layer 3 (Pralrlo du Chlon-Jordan aquifer) 


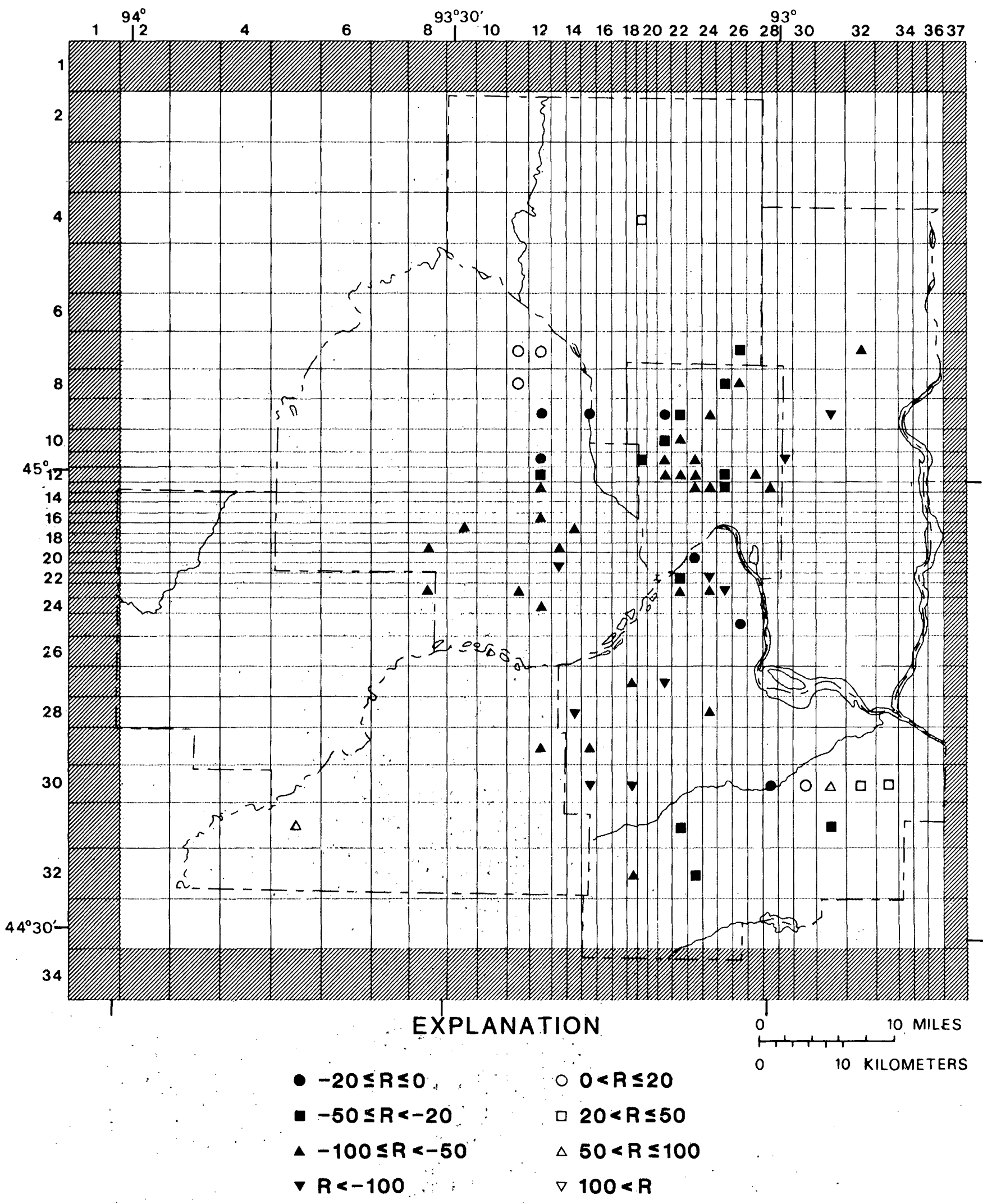

FIgure 25.--Summary of residuals for $1971-77$ simulation, layer 4 (St. Peter aquifer) 


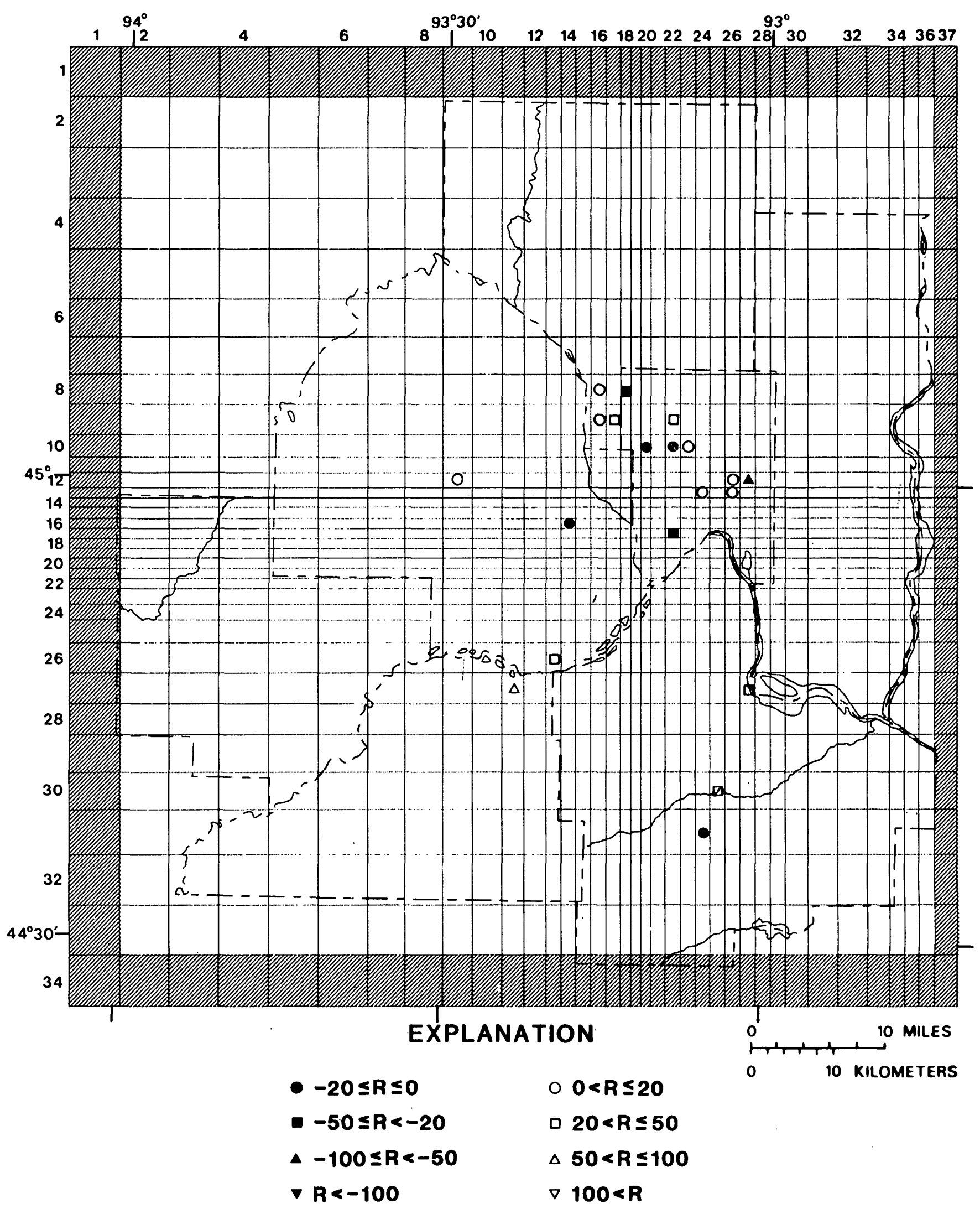

Figure 26.--Summary of residuals for 1971-77 simulation, layer 5 (drift) 
Residuals for the 1971-77 simulation (figs. 23-26) are generally not as good as those for the 1885 simulation. Model-computed potentiometric levels are less than the observed levels for the Prairie du Chien-Jordan and St. Peter aquifers. In addition to the errors possibly introduced by incorrect specification of hydraulic parameters, other possible reasons for generally poor model perfor mance include: (1) estimates of groundwater withdrawal may be grossly in error, and (2) the averaged potentiometric levels used to evaluate model performance may not be representative of modeled conditions. Each of these factors in troduces uncertainties in the model simulation, but the most critical factor probably is inadequate representation of ground-water withdrawals. Likely sources of error in the withdrawal rates used in the 1971-77 simulation are incorrect aquifer designation, incomplete reporting of withdrawals, and insufficient information to estimate average withdrawals. Many of these sources of error will be eliminated during the detailed investigation of ground-water withdrawals that will be undertaken prior to construction of the final flow model.

Other inferences are possible regarding the preliminary model and its ability to simulate the gross properties of the ground-water system. For example, model results for the 1971-77 simulation show that model-computed potentiometric levels are generally too high in layer 1 (Mount Simon-Hinckley aquifer, fig. 23) and generally too low in layer 3 (Prairie du Chien-Jordan aquifer, fig. 24). This suggests that the model simulated leakance coefficients for confining-unit representations 1-2 (Eau Claire) and 2-3 (St. Lawrence-Franconia) may be too high, allowing the model to simulate too much water leaking vertically downward from the Prairie du Chien-Jordan aquifer to the Mount Simon-Hinckley aquifer. This and other possible reasons for the large residuals in the preliminary model simulations will be evaluated in detail during construction and calibration of the final flow model.

\section{Parameter Sensitivity Analyses}

Model-parameter sensitivity is defined as the change in computed potentiometric level caused by an adjust ment in a parameter value. Parameter sensitivity is important because model performance can best be improved by adjusting parameter values to which the model simulations are most sensitive. This process of parameter adjustment is also referred to as model calibration. However, the degree of allowable adjustment is generally directly proportional to the uncertainty of a parameter value. Thus, during attempts to improve model performance through parameter adjustment, both model sensitivity to individual parameters and the uncertainty associated with each parameter must be considered. A principal objective of the preliminary model simulations was to determine the relative sensitivity of a number of parameters judged to be important in simulating the ground-water system. This information will be used to prioritize efforts to refine available hydrologic data and collect new data, leading to the development of a data base best suited for successful simulations of the ground-water system. Also, although no parameter adjustment was performed with the preliminary model, the sensitivity analysis should make the process of calibrating the final model less complex and more efficient.

The sensitivity of 19 parameters was investigated with the preliminary model (table 5). In table 5, model layers and confining-unit representations are numbered as in table 2 and figure 4. Most parameters are self-explanatory, but the parameters described as "where bedrock is missing" are for those parts of the model area where the continuity of aquifers or confining units is interrupted by drift. This occurs in bedrock valleys and where bedrock formations subcrop beneath the drift. The areas where bedrock is missing are shown in figures 4 and 7. The 19 parameters represent the major hydrologic 
properties, stresses, and boundaries of the ground-water-flow system. Table 6 summarizes the change in computed potentiometric level caused by a 10 percent increase in individual parameter values. There is at least a 10 percent uncertainty associated with each of the 19 parameters specified in the preliminary model. For some of the parameters, particularly the leakance coefficients, the uncertainty may be greater than an order of magnitude. The two parameters with the greatest sensitivity to 10-percent changes are QRE and PUMP: Other parameters with relatively high sensitivity to 10-percent changes include TR1, TR5, TK4M, TR4M, TR3A, and TR3M. It is likely that other parameters, such as the leakance coefficients, would also be $h$ ghly sensitive if the change in parameter values were comparable to the level of uncertainty associated with those parameters.

Table 5.-Parameters evaluated in preliminary-model sensitivity analyses

Parameter

Description

TR1

TR2

TR3M

TR3A

TR4M

TR4A

TR5

TK1

TK2M

TK2A

TK3M

TK3A

TK4M

TK4A

QRE

PUMP

LKYR

LKYE

LKY
Transmissivity of layer 1 .

Transmissivity of layer 2 .

Transmissivity of the part of layer 3 where bedrock is missing.

Transmissivity of bedrock part of layer 3 .

Transmissivity of the part of layer 4 where bedrock is missing.

Transmissivity of bedrock part of layer 4 .

Transmissivity of layer 5 .

Leakance coefficient of confining unit 1-2.

Leakance coefficient of the part of confining unit 2-3 where bedrock is missing.

Leakance coefficient of bedrock part of confining unit 2-3.

Leakance coefficient of the part of confining unit 3-4 where bedrock is missing.

Leakance coefficient of bedrock part of confining unit 3-4.

Leakance coefficient of the part of confining unit 4-5 where bedrock is missing.

Leakance coefficient of bedrock part of confining unit 4-5.

Areal recharge.

Pumpage.

Riverbed leakance coefficients.

Grid-edge leakance coefficients.

Spring leakance coefficients. 
Table 6.-Number of model nodes where the absolute value of head change caused by a 10-percent increase in parameter value is greater than 2.0 feet and 10.0 feet

\begin{tabular}{rrr}
\hline & \multicolumn{2}{c}{ Number of model nodes $1 /$} \\
\cline { 2 - 3 } Parameter & $\begin{array}{c}\text { Head change } \\
\text { greater than 2 feet }\end{array}$ & $\begin{array}{c}\text { Head change } \\
\text { greater than } 10 \text { feet }\end{array}$ \\
\hline & 501 & $35 /$ \\
TR1 & 39 & 35 \\
TR2 & 127 & 35 \\
TR3M & 188 & 35 \\
TR3A & 225 & 35 \\
TR4M & & \\
& 37 & 35 \\
TR4A & 301 & 36 \\
TR5 & 42 & 35 \\
TK1 & 37 & 35 \\
TK2M & 72 & 35 \\
TK2A & & 35 \\
TK3M & 86 & 35 \\
TK3A & 38 & 35 \\
TK4M & 241 & 35 \\
TK4A & 37 & 285 \\
QRE & 3595 & 109 \\
PUMP & & 35 \\
LKYR & 2611 & 35 \\
LKYE & 77 & 35 \\
LKYS & 37 & \\
& 37 & \\
\hline
\end{tabular}

$\underline{1}$ Active nodes in model equals 4,761 .

2/Thirty-five nodes are common to all parameters and probably represent sensitivity to a boundary-condition specification.

\section{CHEMICAL QUALITY OF GROUND WATER}

The quality of water in bedrock and drift aquifers in the Twin Cities metropolitan area was described in detail by Maderak (1963) from analyses that were tabulated from Prior and others (1953) and from files of the U.S. Geological Survey and Minnesota Department of Health. From this data base, Maderak (1964; 1965) qualitatively determined that (1) concentrations of dissolved solids generally decrease from the west and southwest to the nor theast in the St. Peter, Prairie du Chien-Jordan, Ironton-Galesville, and Mount Simon-Hinckley aquifers, (2) drift composition has little influence on the type of ground water, (3) the average concentration of dissolved solids is greatest in water from the gray, calcareous drift deposited by the Des Moines Lobe and least in water from the Jordan Sandstone, and (4) the average concentration of silica is least in water from the Mount Simon-Hinckley aquifer. 
Norvitch and others (1973) calculated the median and range of concentrations of dissolved solids and individual dissolved constituents for a large number of ground-water samples from the principal aquifers in the Twin Cities metropolitan area (table 7). In this investigation of ground-water quality, the Jordan Sandstone was treated separately from the Prairie du Chien Group. A Piper diagram of median concentrations (Norvitch and others, 1973) of major dissolved constituents indicates that ground water in the area can be classified generally as a mixed calcium magnesium bicarbonate type (fig. 27).

\section{Table 7.-Median and range of concentrations for selected constituents in water from principal bedrock units and drift in the Twin Cities metropolitan area (after Norvitch and others, 1973)}

[All concentrations in milligrams per liter, except as indicated]

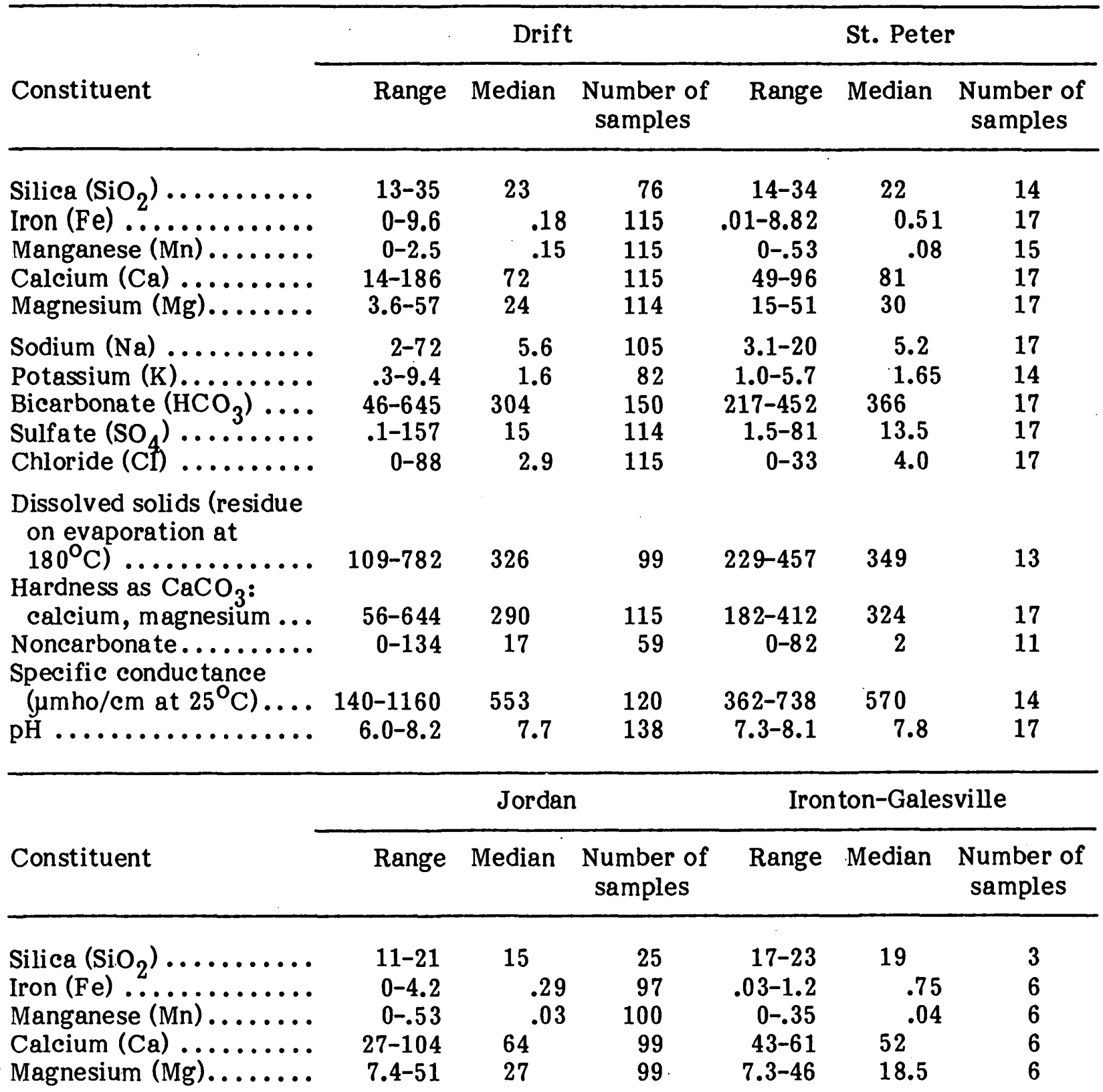


Table 7.-Median and range of concentrations for selected constituents in water from principal bedrock units and drift in the Twin Cities metropolitan area (after Norvitch and others, 1973)-Continued

\begin{tabular}{|c|c|c|c|c|c|c|}
\hline \multirow[b]{2}{*}{ Constituent } & \multicolumn{3}{|c|}{ Jordan } & \multicolumn{3}{|c|}{ Ironton-Galesville } \\
\hline & Range & Median & $\begin{array}{l}\text { Number of } \\
\text { samples }\end{array}$ & Range & Median & $\begin{array}{l}\text { Number of } \\
\text { samples }\end{array}$ \\
\hline $\begin{array}{l}\text { Sodium }(\mathrm{Na}) \ldots \ldots \ldots \ldots \\
\text { Potassium }(\mathrm{K}) \ldots \ldots \ldots \ldots \\
\text { Bicarbonate }\left(\mathrm{HCO}_{3}\right) \ldots \ldots \\
\text { Sulfate }\left(\mathrm{SO}_{4}\right) \ldots \ldots \ldots \ldots \\
\text { Chloride }(\mathrm{C}) \ldots \ldots\end{array}$ & $\begin{array}{r}0-44 \\
.8-4.0 \\
134-537 \\
.1-89 \\
0-37\end{array}$ & $\begin{array}{c}4.5 \\
1.75 \\
305 \\
7.5 \\
1.6\end{array}$ & $\begin{array}{r}91 \\
28 \\
101 \\
99 \\
99\end{array}$ & $\begin{array}{r}3-16 \\
1.2-2.0 \\
183-415 \\
3-31 \\
.7-10\end{array}$ & $\begin{array}{l}5.75 \\
1.3 \\
255 \\
5 \\
1.8\end{array}$ & $\begin{array}{l}5 \\
4 \\
6 \\
6 \\
6\end{array}$ \\
\hline \multirow[t]{3}{*}{ 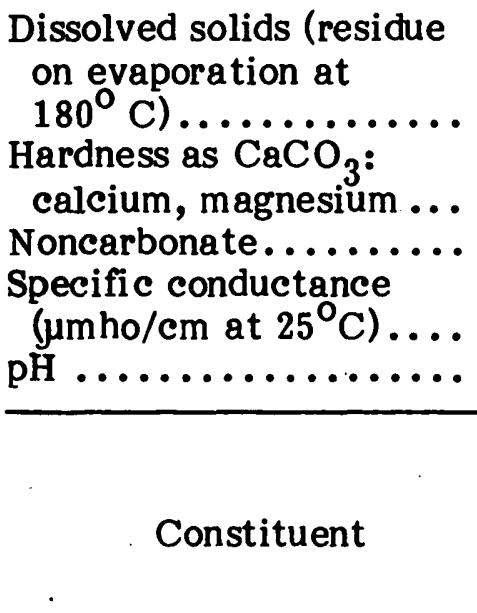 } & $\begin{array}{r}136-640 \\
106-460 \\
0-28 \\
\\
220-646 \\
6.6-8.2\end{array}$ & $\begin{array}{r}275 \\
251 \\
0 \\
456 \\
7.6\end{array}$ & $\begin{array}{r}64 \\
\\
100 \\
24 \\
\\
49 \\
97\end{array}$ & $\begin{array}{r}180-400 \\
150-340 \\
0 \\
\\
240-457 \\
7.0-7.6\end{array}$ & $\begin{array}{c}2.54 \\
195 \\
0 \\
405 \\
7.4\end{array}$ & $\begin{array}{l}6 \\
6 \\
1 \\
4 \\
6\end{array}$ \\
\hline & & \multicolumn{5}{|c|}{ Mount Simon-Hinckley $1 /$} \\
\hline & & Range & \multicolumn{2}{|r|}{ Median } & \multicolumn{2}{|c|}{$\begin{array}{l}\text { Number of } \\
\text { samples }\end{array}$} \\
\hline $\begin{array}{l}\text { Silica }\left(\mathrm{SiO}_{2}\right) \ldots \ldots \\
\text { Iron }(\mathrm{Fe}) \ldots \ldots \ldots \\
\text { Manganese }(\mathrm{Mn}) \\
\text { Calcium }(\mathrm{Ca}) . . \\
\text { Magnesium }(\mathrm{Mg}) .\end{array}$ & $\begin{array}{l}\ldots \ldots \ldots \ldots \\
\cdots \ldots \ldots \ldots \\
\ldots \ldots \ldots \ldots \\
\ldots \ldots \ldots \ldots \\
\ldots \ldots \ldots \ldots\end{array}$ & $\begin{array}{r}7.3-32 \\
.02-.83 \\
0-1.1 \\
11-100 \\
6.4-53\end{array}$ & & $\begin{array}{l}19 \\
.76 \\
54 \\
20\end{array}$ & $\begin{array}{l}19 \\
55 \\
54 \\
55 \\
55\end{array}$ & \\
\hline $\begin{array}{l}\text { Sodium }(\mathrm{Na}) \ldots . \\
\text { Potassium }(\mathrm{K}) \ldots \\
\text { Bicarbona te }(\mathrm{HCC} \\
\text { Sulfate }\left(\mathrm{SO}_{4}\right) \ldots \\
\text { Chloride }(\mathrm{Cl}) \ldots\end{array}$ & $\begin{array}{l}\cdots \ldots \ldots \ldots \\
\cdots \ldots \ldots \ldots \\
\cdots \ldots \ldots \ldots \\
\cdots \ldots \ldots \ldots \\
\cdots \ldots \ldots\end{array}$ & $\begin{array}{r}0-180 \\
1-6.8 \\
61-537 \\
.3-67 \\
.5-190\end{array}$ & & $\begin{array}{c}10.5 \\
2 \\
268 \\
5 \\
5.1\end{array}$ & $\begin{array}{l}48 \\
25 \\
55 \\
52 \\
54\end{array}$ & \\
\hline $\begin{array}{l}\text { Dissolved solids } \\
\text { (residue on evap } \\
\text { tion at } 180^{\circ} \mathrm{C} \text { ) } \\
\text { Hardness as CaCC } \\
\text { calcium, magnes } \\
\text { Noncarbonate... } \\
\text { Specific conducta } \\
\text { ( } \mu \text { mho/cm at } 25^{\circ} \\
\text { pH ............ }\end{array}$ & $\begin{array}{l}r a \\
\ldots \ldots \ldots \ldots \\
3 \\
\text { um } \ldots \ldots \ldots \\
\ldots \ldots \ldots \ldots \\
\text { ce } \\
\text { C) } \ldots \ldots \ldots \\
\ldots \ldots \ldots\end{array}$ & $\begin{array}{r}79-660 \\
\text { - } \quad 54-430 \\
0-19 \\
\text { - } 230-797 \\
\text { - } 6.2-8.0\end{array}$ & & $\begin{array}{l}446 . \\
7.6\end{array}$ & $\begin{array}{l}28 \\
54\end{array}$ & \\
\hline
\end{tabular}

1/Includes analyses from wells north of Twin Cities metropolitan area. 


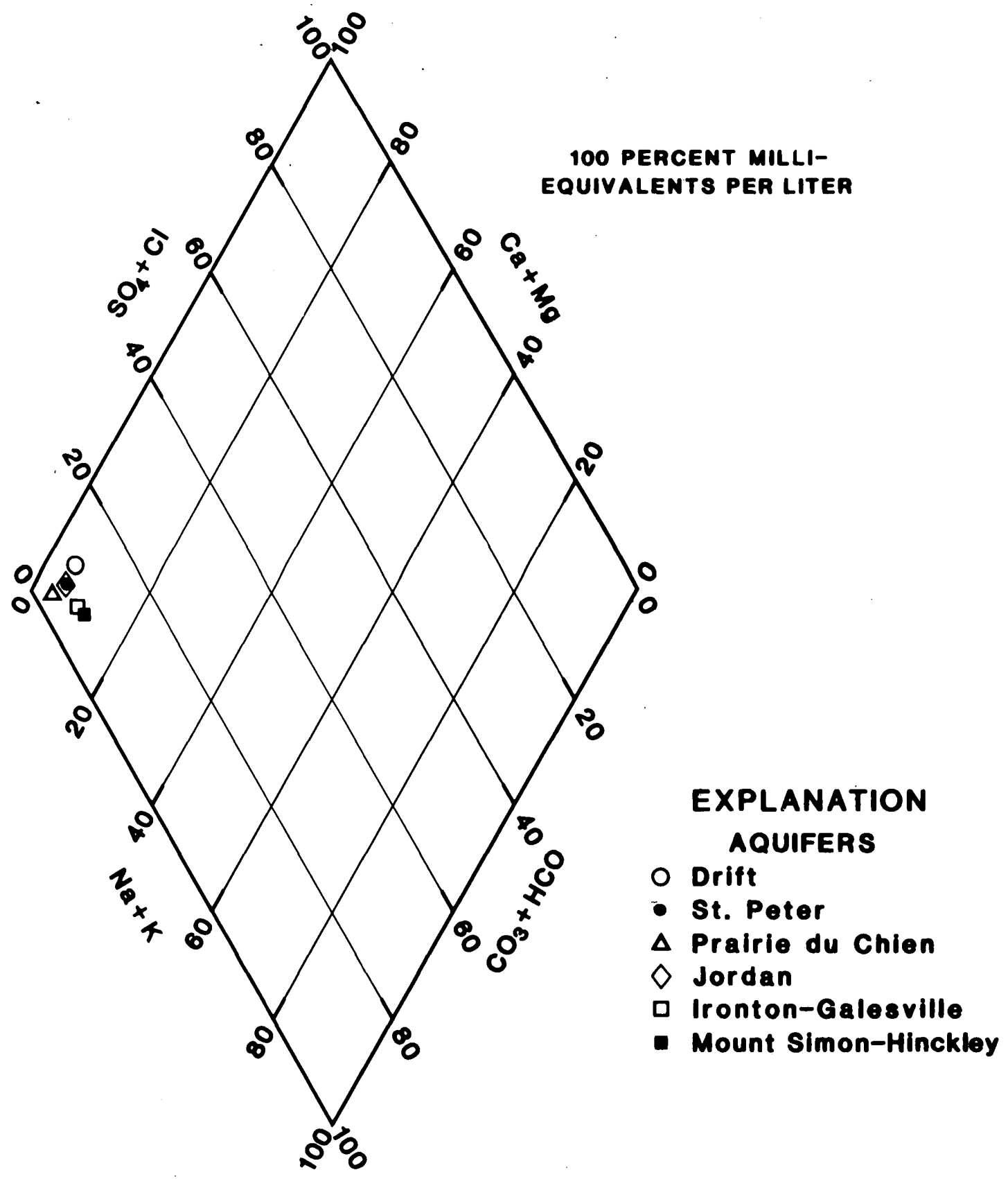

Figure 27.---Piper diagram of median concentrations of malor dlssolved constituents in. water from the princlple aquifers In the Twin Citles metropolitan area 
Although the summary statistics used by Maderak and Norvitch are useful tools to describe overall ground-water quality, a better understanding of water quality can be gained by examining areal distribution of individual dissolved constituents. Areal distributions not only characterize water quality, but trends in the data may also provide infor mation on the hydrologic and geochemical relationships between aquifers.

Consequently, a series of maps was prepared from data in the U.S. Geological Survey WATSTORE data base of the areal distribution of dissolved solids, calcium, sodium, sulfate, and chloride in water from the drift and the two major bedrock aquifers in the Twin Cities metropolitan area, the Jordan Sandstone and the Mount Simon-Hinckley aquifer. These maps show distinct areal trends in ground-water quality across the study area. Because the composition and distribution of hydrogeologic units influence groundwater quality, the geology of the system must be considered when analyzing observed water-quality trends. Figure 28 shows important aspects of the geology of the drift and the Jordan Sandstone that may influence water quality. Two different drift types were deposited in the Twin Cities area, the Des Moines Lobe drift in the western two-thirds of the study area and the Superior Lobe drift in the eastern one-third. The two drift types have different lithologic composition and may influence ground-water quality differently. Figure 28 also shows that the western and northern edges of the Jordan Sandstone subcrop beneath drift. Cretaceous deposits may also affect water quality in the study area because they overlie the Jordan Sandstone west and southwest of the study area (Sims, 1970). The Mount Simon-Hinckley aquifer underlies the entire study region, and its water quality may be influenced in a variety of ways because of the complex distribution of hydrogeologic units that overlie it.

\section{Dissolved Solids}

Concentrations of dissolved solids in ground water generally decrease from between 500 and $600 \mathrm{mg} / \mathrm{L}$ in the west and southwest part of the study area to about $200 \mathrm{mg} / \mathrm{L}$ in the northeast (figs. 29-31). This trend occurs in the drift and in both bedrock aquifers and suggests either that similar processes are releasing dissolved constituents or that there are common sources of major dissolved constituents. The trend in dissolved solids is probably related to the mineral composition of the drift through which most recharge to the bedrock aquifers occurs. The bedrock aquifers receive much of their recharge where they are directly overlain by the drift or where they are cut by buried bedrock valleys. In the Twin Cities metropolitan area, about half the area of the Jordan Sandstone is directly overlain by the drift and about half by younger bedrock (fig. 28). Except where intersected by buried bedrock valleys, the Mount Simon-Hinckley aquifer is overlain by younger bedrock in the study area. However, in a band about 10 miles wide immediately west of the Twin Cities, the Mount Simon-Hinckley aquifer is overlain by drift and Cretaceous rocks (Sims, 1970). Also, north of the Twin Cities, the aquifer crops out or subcrops beneath sandy drift and recharge to the aquifer is rapid.

Generally, drift in the eastern part of the study area was deposited by the Superior Lobe of the Laurentian Ice Sheet, which came from northeast Minnesota. The composition of the drift, derived from basalts on the North Shore of Lake Superior and crystalline rocks north of Lake Superior, is predominantly silicate minerals that weather more slowly than the carbonate minerals found in the younger Des Moines Lobe drift located in the western part of the Twin Cities metropolitan area (fig. 28). Concentrations of dissolved solids in water from Superior Lobe drift nor theast of the Twin Cities, and bedrock aquifers in the northeastern part of the study area, are generally less than $300 \mathrm{mg} / \mathrm{L}$. Des Moines Lobe drift contains carbonate-rock fragments derived from limestone and 


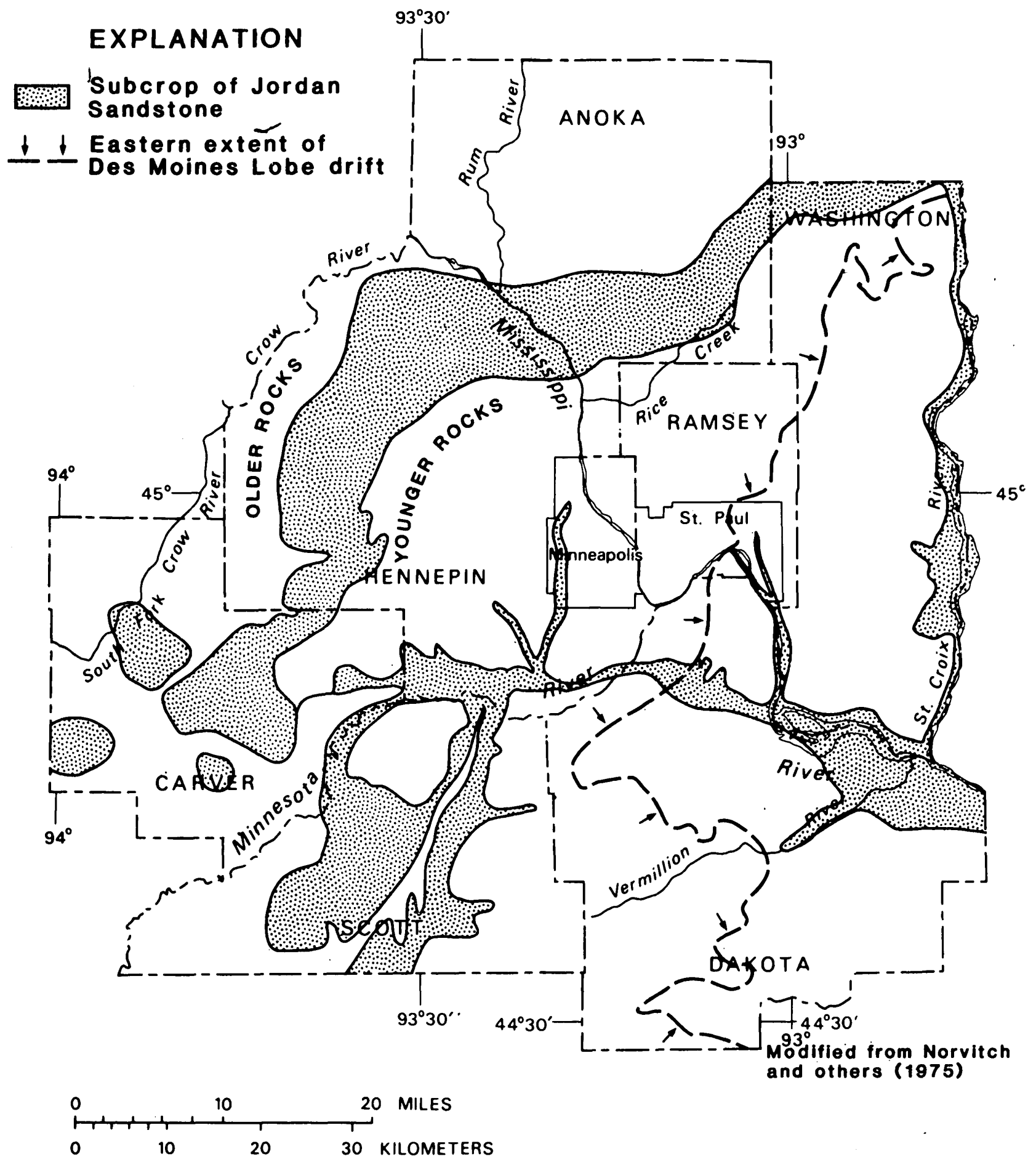

Figure 28.--The eastern extent of the Des Moines Lobe drift and subcrop of the Jordan Sandstone 


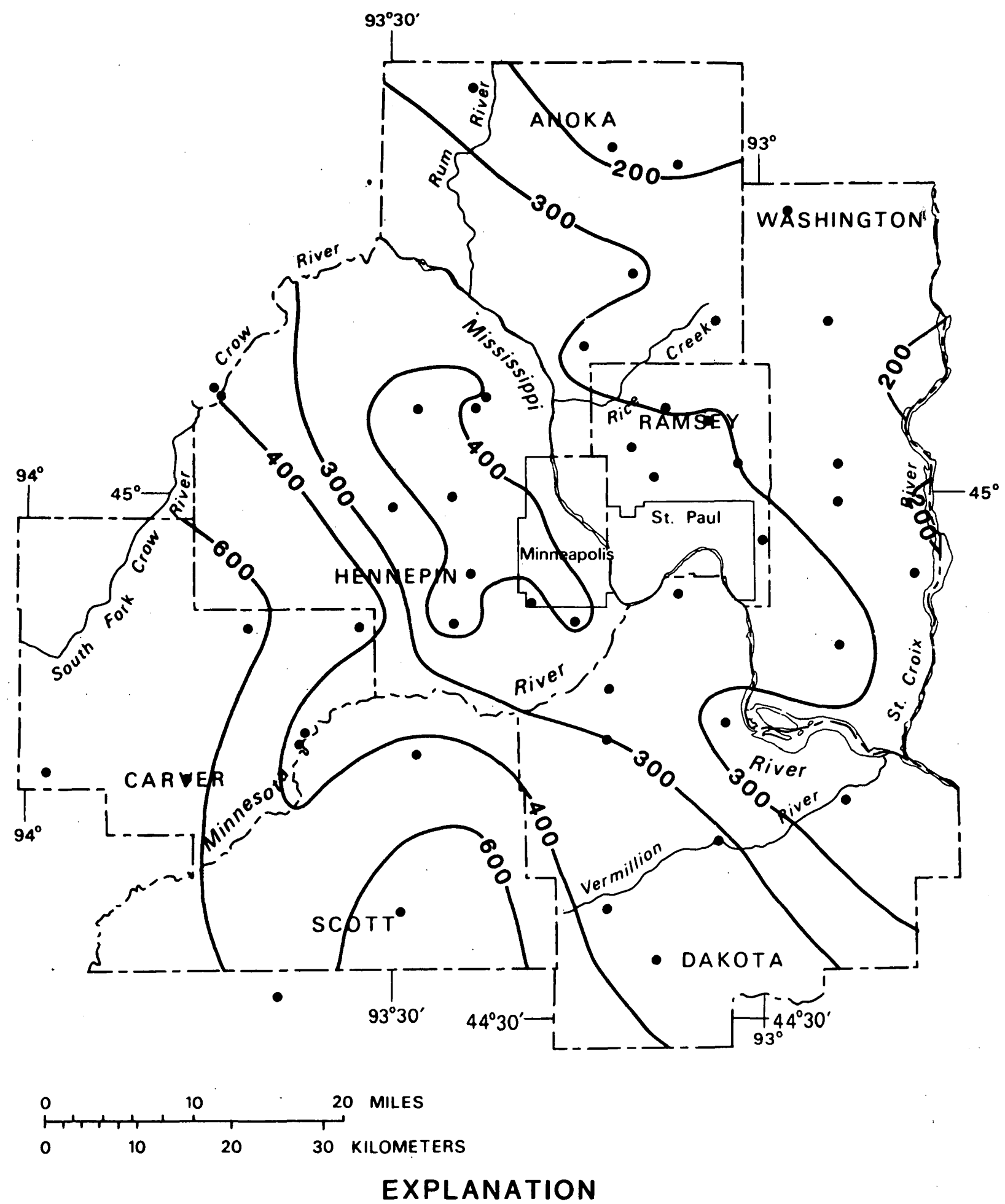

i 200 LINE OF EQUAL DISSOLVED-SOLIDS CONCENTRATION-Interval, in milligrams per liter, is 100 and 200

- Data point

Figure 29.--Lines of equal concentration of dissolved solids in water from the drift 


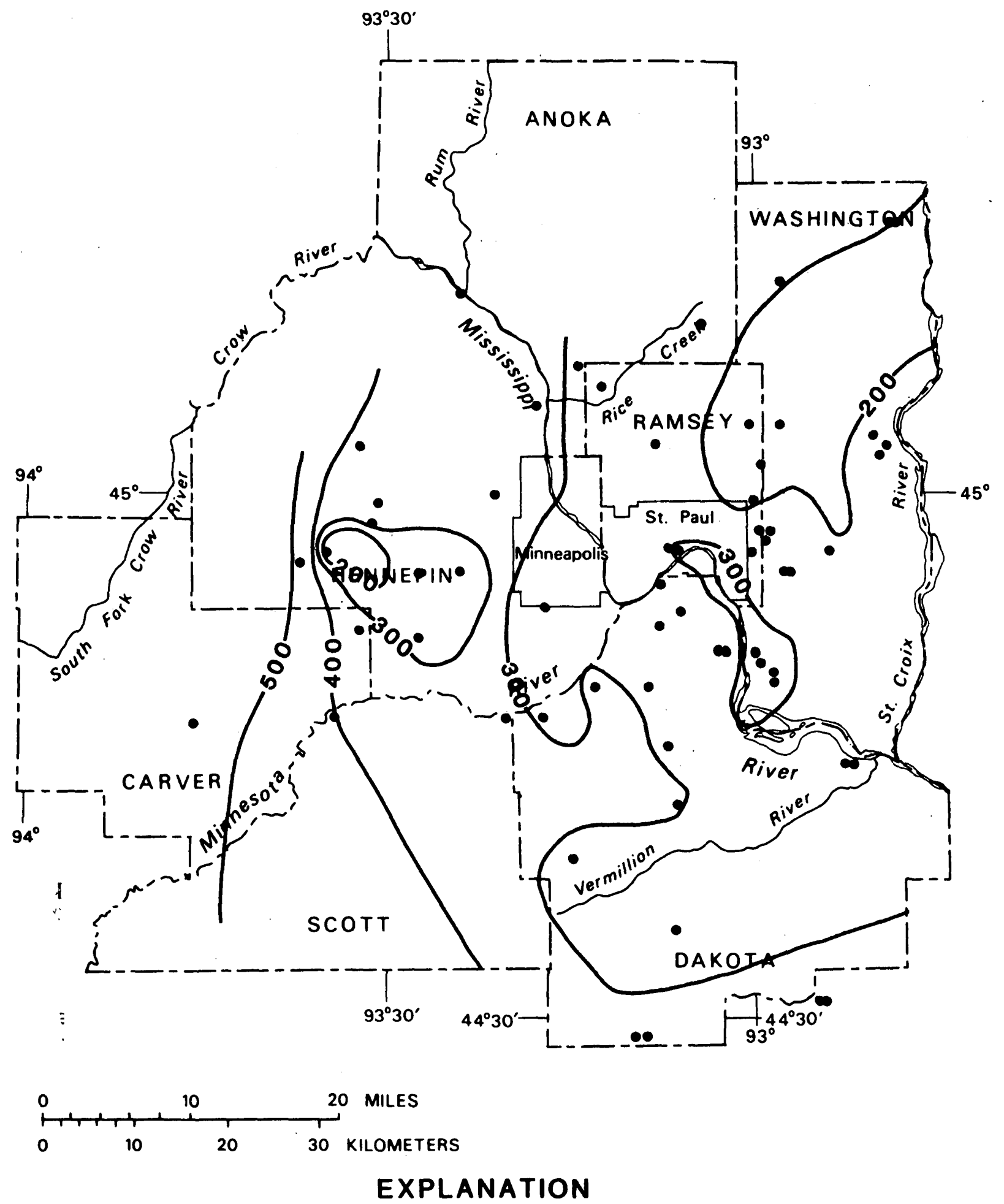

- $200-$ LINE OF EQUAL DISSOLVED-SOLIDS CONCENTRATION-Interval, in milligrams per liter, is $\mathbf{1 0 0}$

- Data point

Figure 30.--Lines of equal concentration of dissolved sollds in water from the Jordan Sandstone 

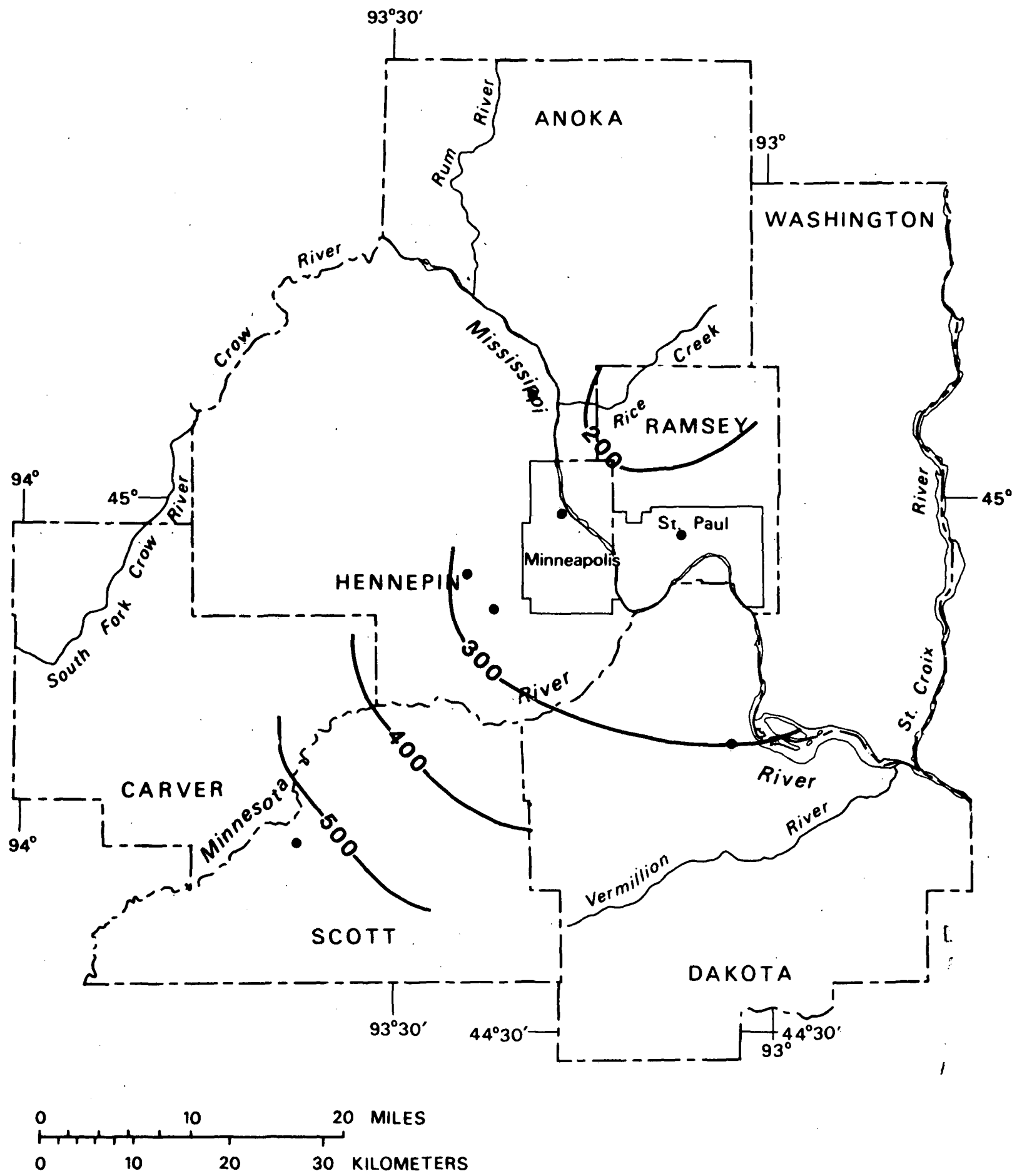

\section{EXPLANATION}

- 200 - LINE OF EQUAL DISSOLVED-SOLIDS CONCENTRATION-Interval, in milligrams per liter, is 100

- Data point

Figure 31.--Lines of equal concentration of dissolved sollds in water from the Mount Simon-Hinckley aquifer 
dolomite in Manitoba, fragments of siliceous shale from the Dakotas, and clay and sandstone fragments from Cretaceous rocks in western Minnesota. Water from both drift and Cretaceous bedrock west of the Twin Cities metropolitan area generally has dissolved solids greater than $500 \mathrm{mg} / \mathrm{L}$ (Novitzki and others, 1969; Van Voast and others, 1972; Winter, 1974). Concentrations of dissolved solids are also about $500 \mathrm{mg} / \mathrm{L}$ in water from the Jordan Sandstone and Mount Simon-Hinckley aquifer in the western part of the study area, reflecting recharge from the overlying drift and possibly Cretaceous rocks.

Dissolved-solids concentrations in water from the Jordan Sandstone are about 100 $\mathrm{mg} / \mathrm{L}$ less in the vicinity of Lake Minnetonka, western Hennepin County, than in the surrounding area. Maderak (1964) first recognized this local decrease in concentration and interpreted it as indicative of recharge from the lake to the underlying aquifers. There is little published data on the concentrations of major constituents in water from Lake Minnetonka. However, a sample of water collected from the lake in October 1961 had a combined milliequivalence of major dissolved constituents of about 6.5 (Megard, 1972). This is equal to about 60 percent of the median milliequivalence of major dissolved constituents in water from the Jordan Sandstone, and lends support to the recharge hypothesis if the decrease in dissolved solids in water from the Jordan is caused by simple dilution.

\section{Sulfate, Calcium, Sodium, and Chloride}

Maps of concentrations of sulfate (figs. 32-34) indicate that sulfate concentrations in water from the drift are generally greater than sulfate in water from the underlying Jordan Sandstone. Concentrations of sulfate in the Mount Simon-Hinckley are greater than $100 \mathrm{mg} / \mathrm{L}$ in Scott County, immediately east of Cretaceous deposits that directly overlie the aquifer. Based on scant data, concentrations of sulfate in the drift in southeastern Hennepin County may also be above $100 \mathrm{mg} / \mathrm{L}$.

Dissolved calcium, the major constituent contributing to the hardness of water, similarly decreases from west to east in the drift, Jordan Sandstone, and Mount SimonHinckley aquifer (figs. 35-37). Concentrations of calcium in water from the Mount Simon-Hinckley are slightly less in the western part of the study area than in water from the drift or Jordan Sandstone.

Dissolved sodium, a major constituent in some water from Cretaceous deposits southwest of the Twin Cities metropolitan area, decreases in water from drift from as much as 50 to less than $10 \mathrm{mg} / \mathrm{L}$ within a distance of about 20 miles in Scott County (fig. 38). Concentrations of sodium may exceed $100 \mathrm{mg} / \mathrm{L}$ in drift in the extreme southwestern part of Scott County. Sodium concentrations similarly decrease in water from the Jordan Sandstone (fig. 39) but range from about 30 to less than $5 \mathrm{mg} / \mathrm{L}$. Concentrations of sodium in the Mount Simon-Hinckley aquifer (fig. 40) decrease from about 40 to 10 $\mathrm{mg} / \mathrm{L}$ from southwest to northeast. These concentrations are higher than in the overlying Jordan Sandstone and drift.

Concentrations of chloride range from less than 1 to about $10 \mathrm{mg} / \mathrm{L}$ in water from the drift and from the Jordan Sandstone (figs. 41 and 42). Chloride concentrations in the Mount Simon-Hinckley aquifer (fig. 43) range from 10 to $20 \mathrm{mg} / \mathrm{L}$, and may increase towards the center of the Twin Cities basin. 


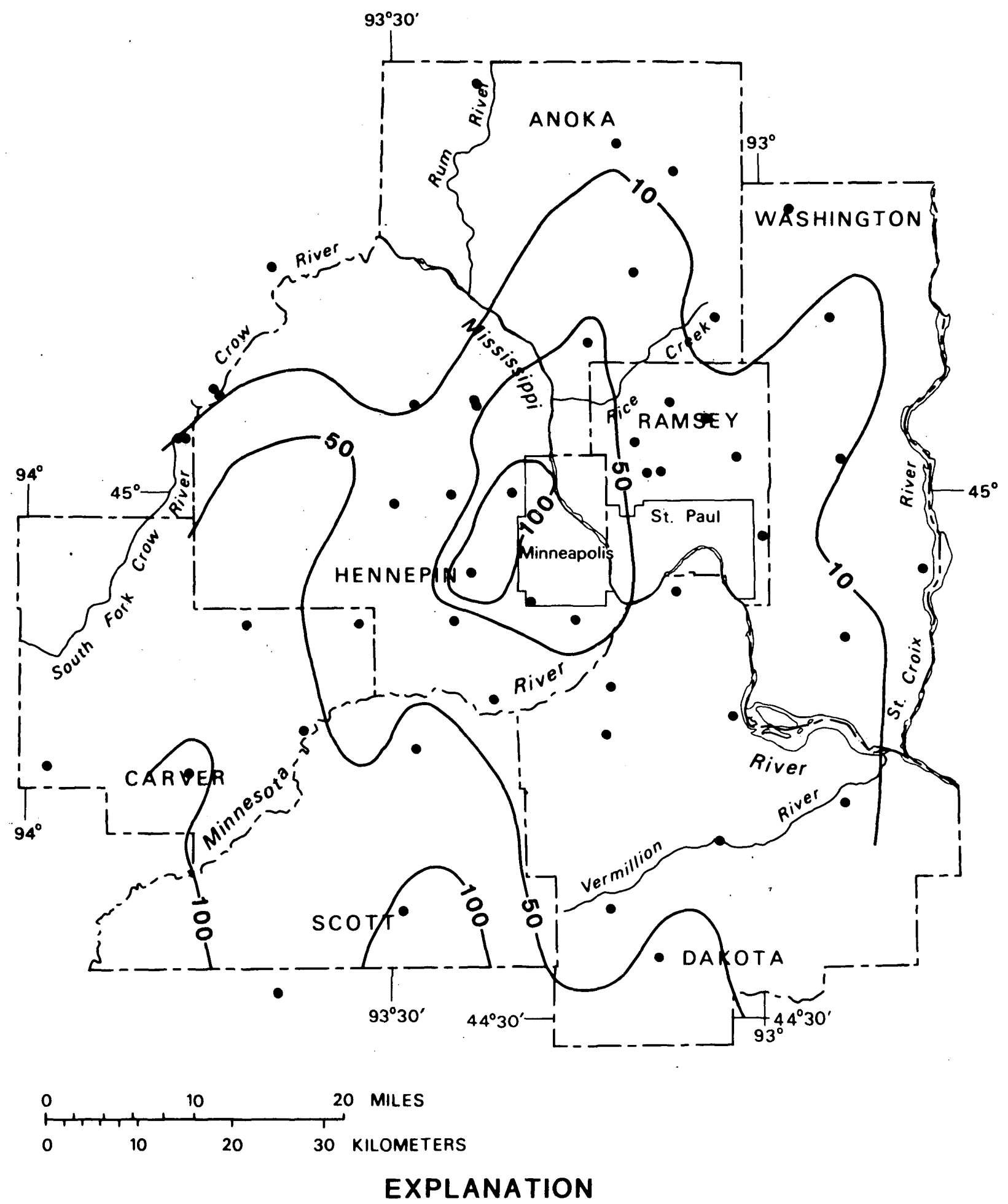

— $100-$ LINE OF EQUAL DISSOLVED-SULFATE CONCENTRATION-Interval, in milligrams per liter, is 40 and 50 .

- Data point

Figure 32.--Lines of equal concentration of dissolved sulfate in water from the drift 


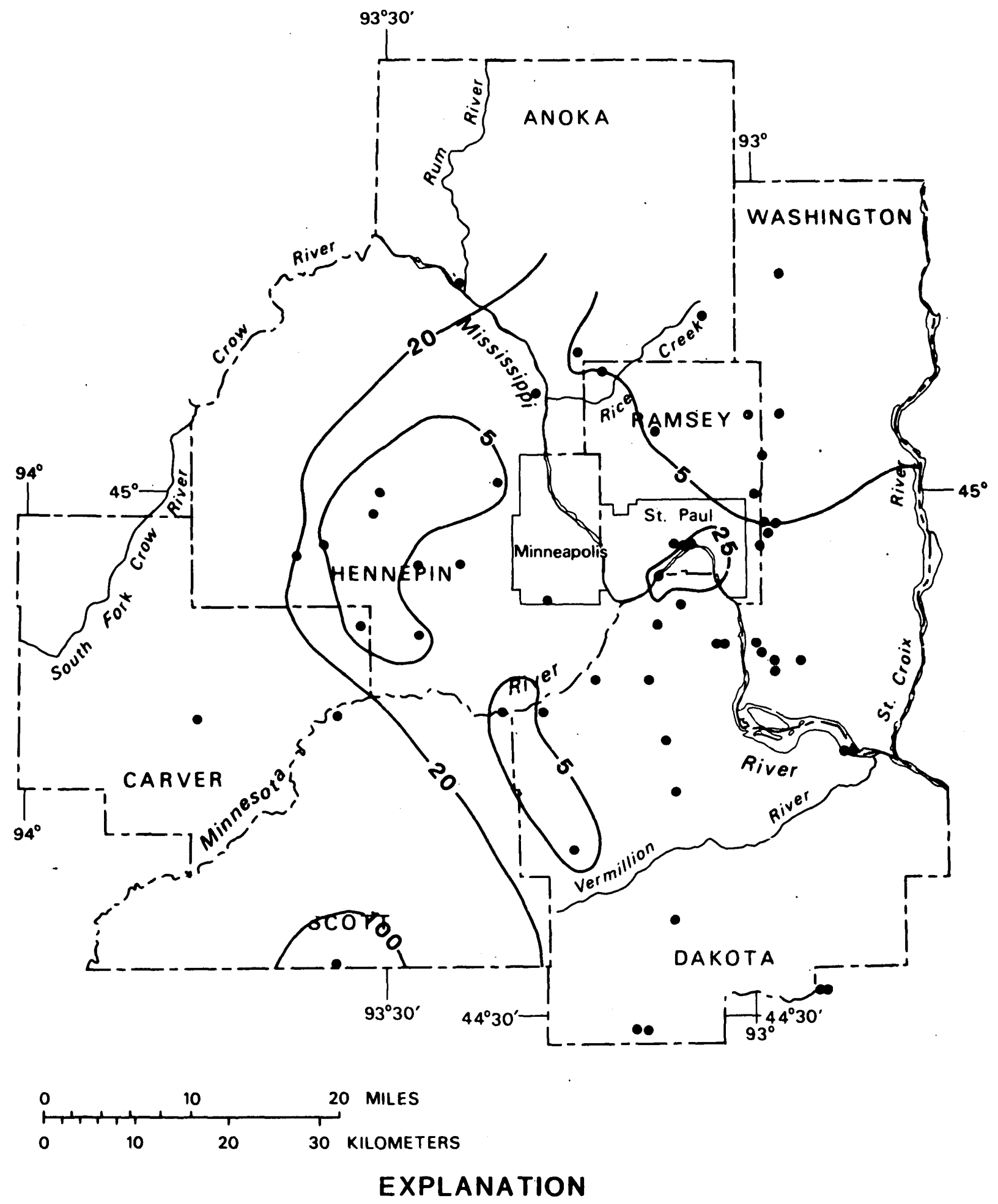

- 100 - LINE OF EQUAL DISSOLVED-SULFATE CONCENTRATION-Interval, in milligrams per liter, is 15, 20 and 80

- Data point

Figure 33.--Lines of equal concentration of dissolved sulfate in water from the Jordan Sandstone 


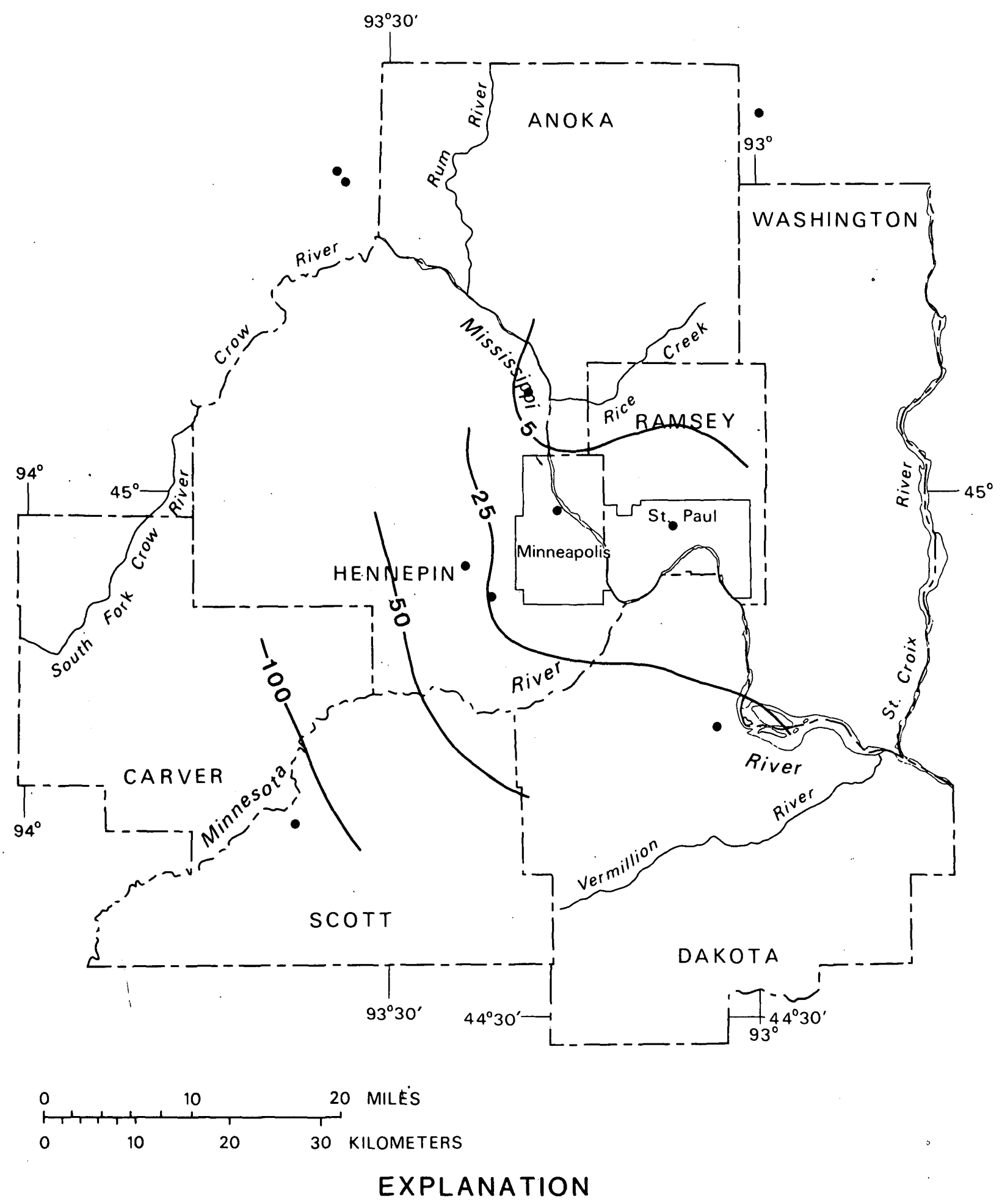

— 100 - LINE OF EQUAL DISSOLVED-SULFATE CONCENTRATION-Interval, in milligrams per liter, is 20,25 and 50

- Data point

Figure 34.--Lines of equal concentration of dissolved sulfate in water from the Mount Simon-Hinckley aquifer 


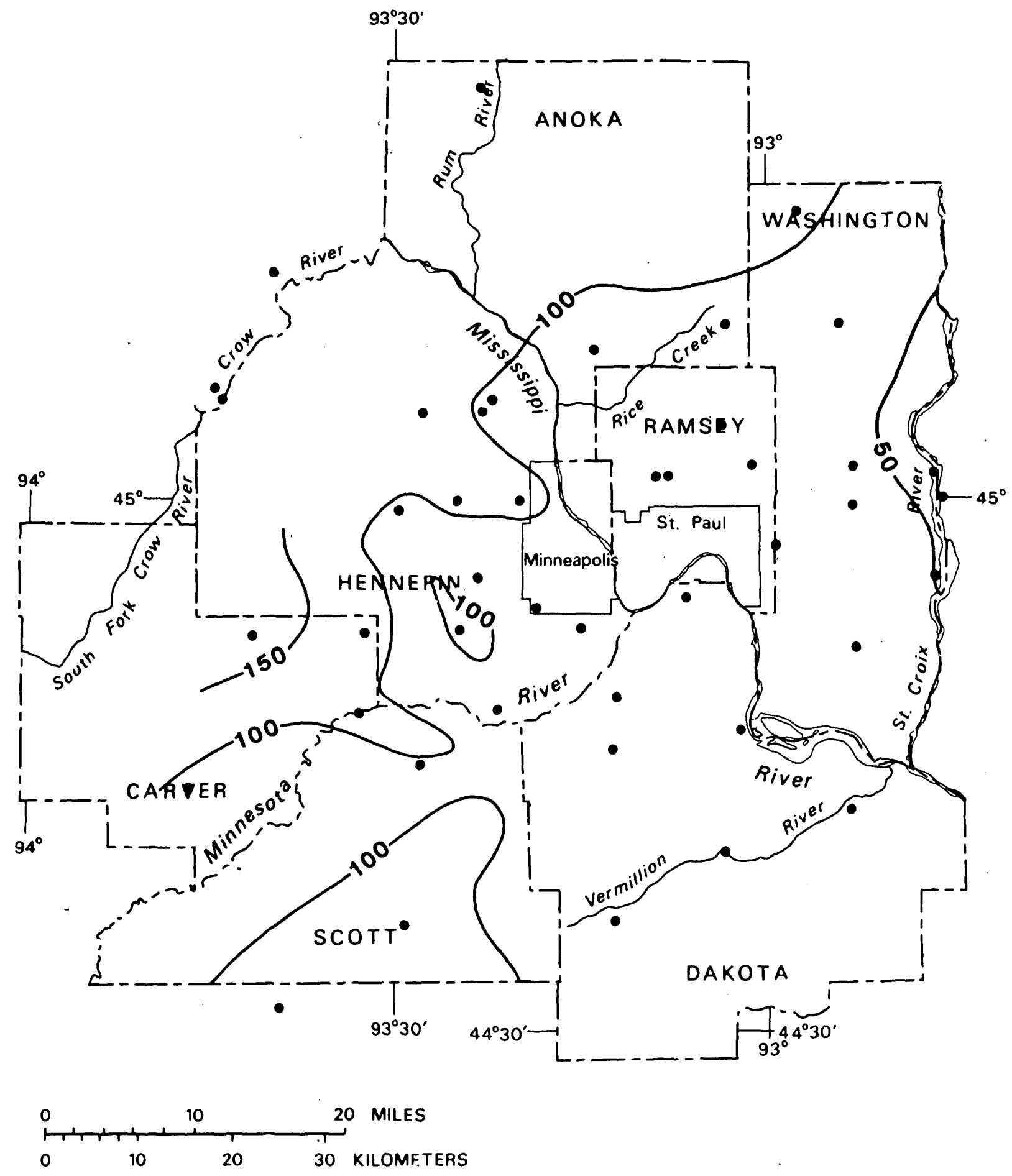

EXPLANATION

— 100 - LINE OF EQUAL DISSOLVED-CALCIUM CONCENTRATION-Interval, in milligrams per liter, is $\mathbf{5 0}$

- Data point

Figure 35.--Lines of equal concentration of dissolved calcium in water from the drift 

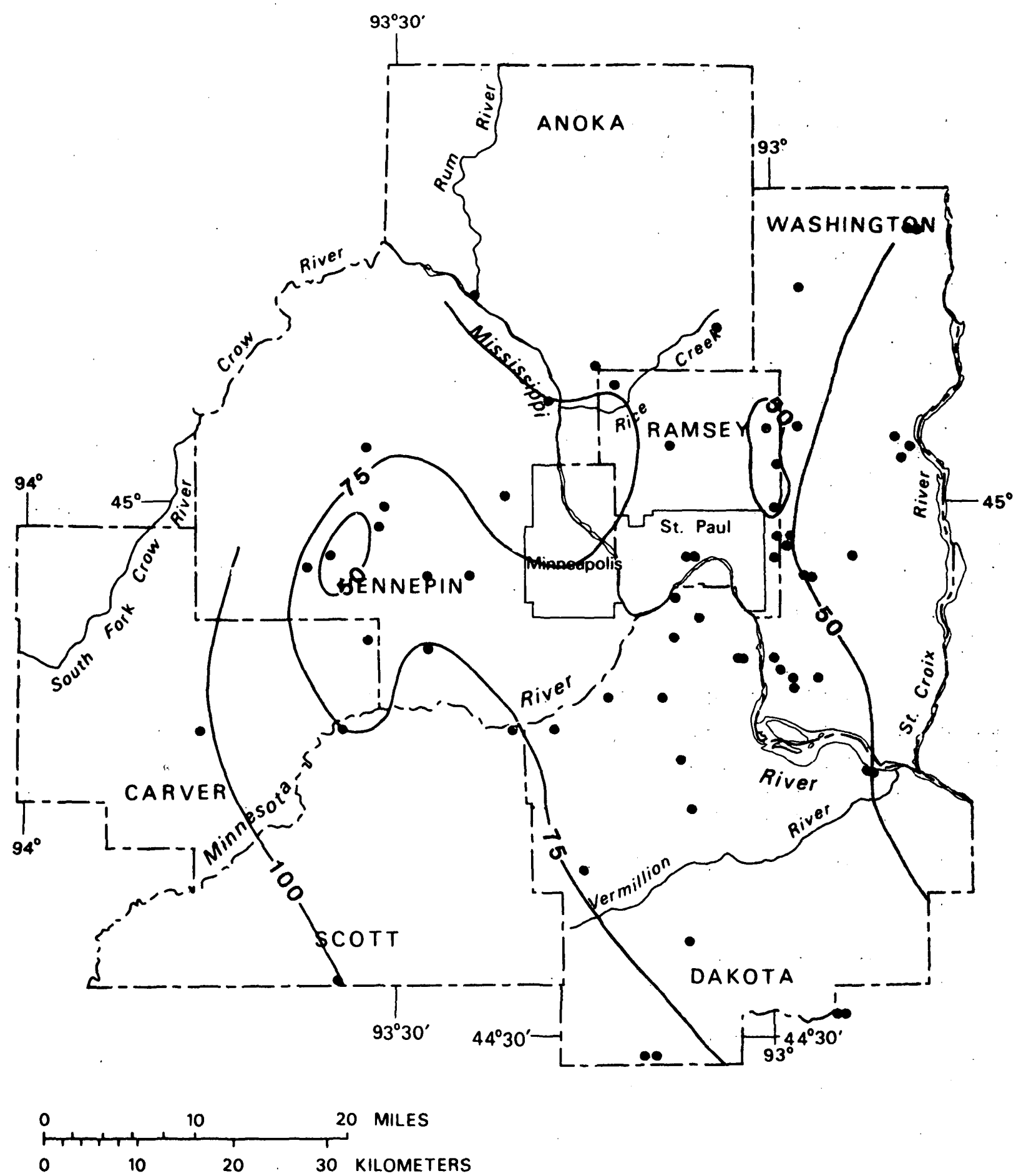

\section{EXPLANATION}

100 - LINE OF EQUAL DISSOLVED-CALCIUM CONCENTRATION-Interval, in milligrams per liter, is 25

- Data point

Figure 36.--Lines of equal concentration of dissolved calcium in water from the Jordan Sandstone 


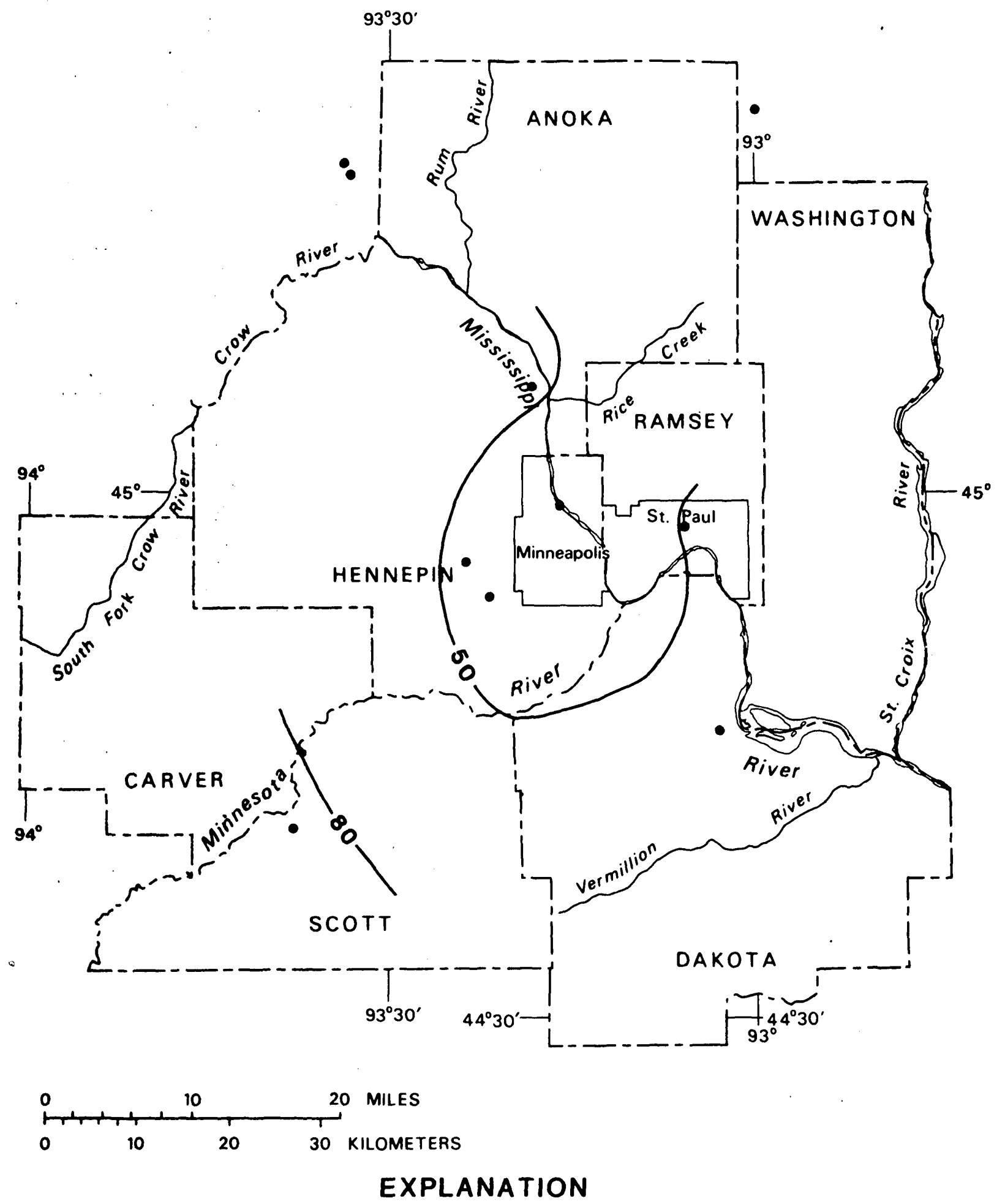
- 80 - LINE OF EQUAL DISSOLVED-CALCIUM CONCENTRATION-- Interval, in milligrams per liter, is $\mathbf{3 0}$
- Data point

Figure 37.--Lines of equal concentration of dissolved calcium in water from the Mount Simon-Hinckley aquifer 


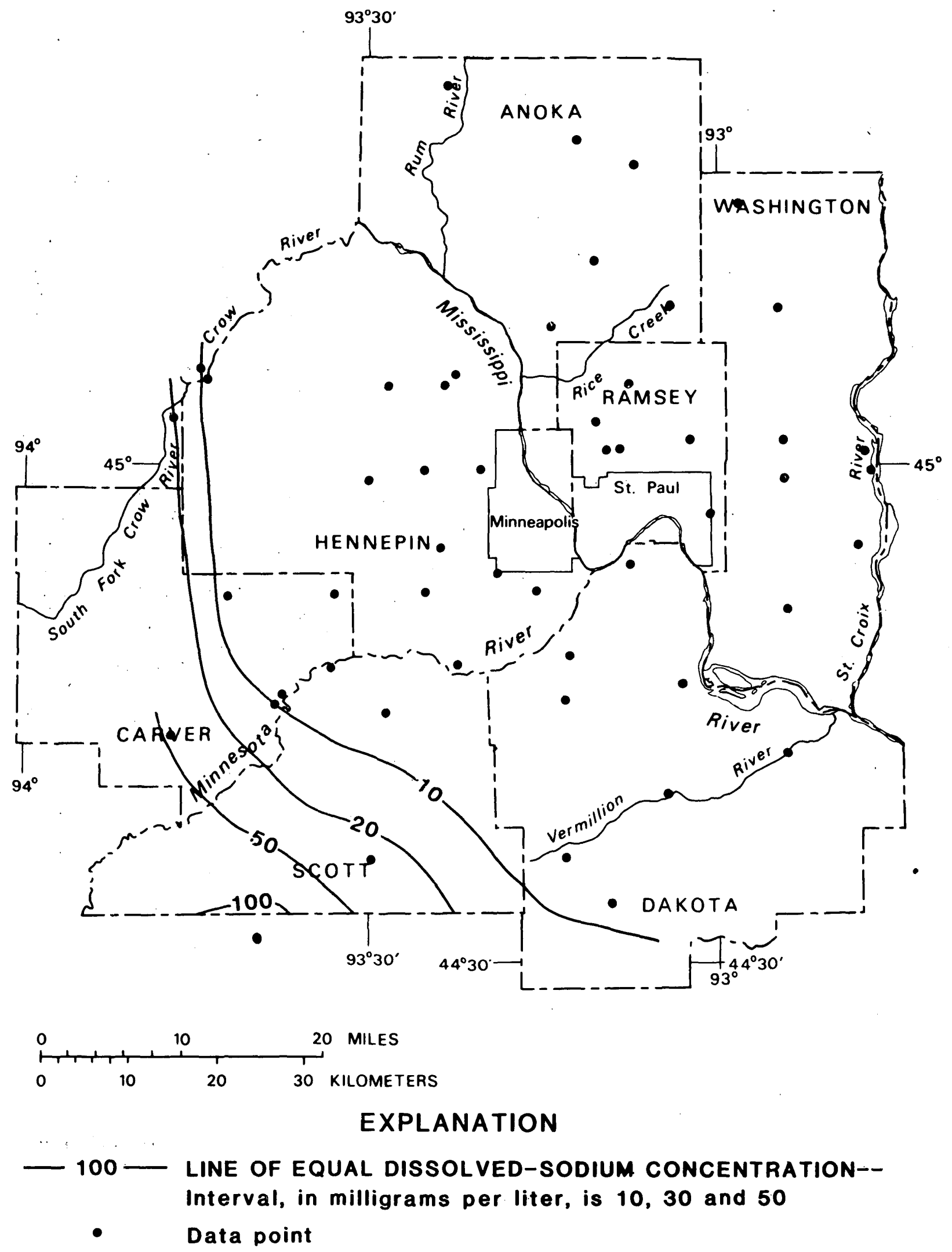

Figure 38.--Lines of equal concentration of dissolved sodium in water from the drift 


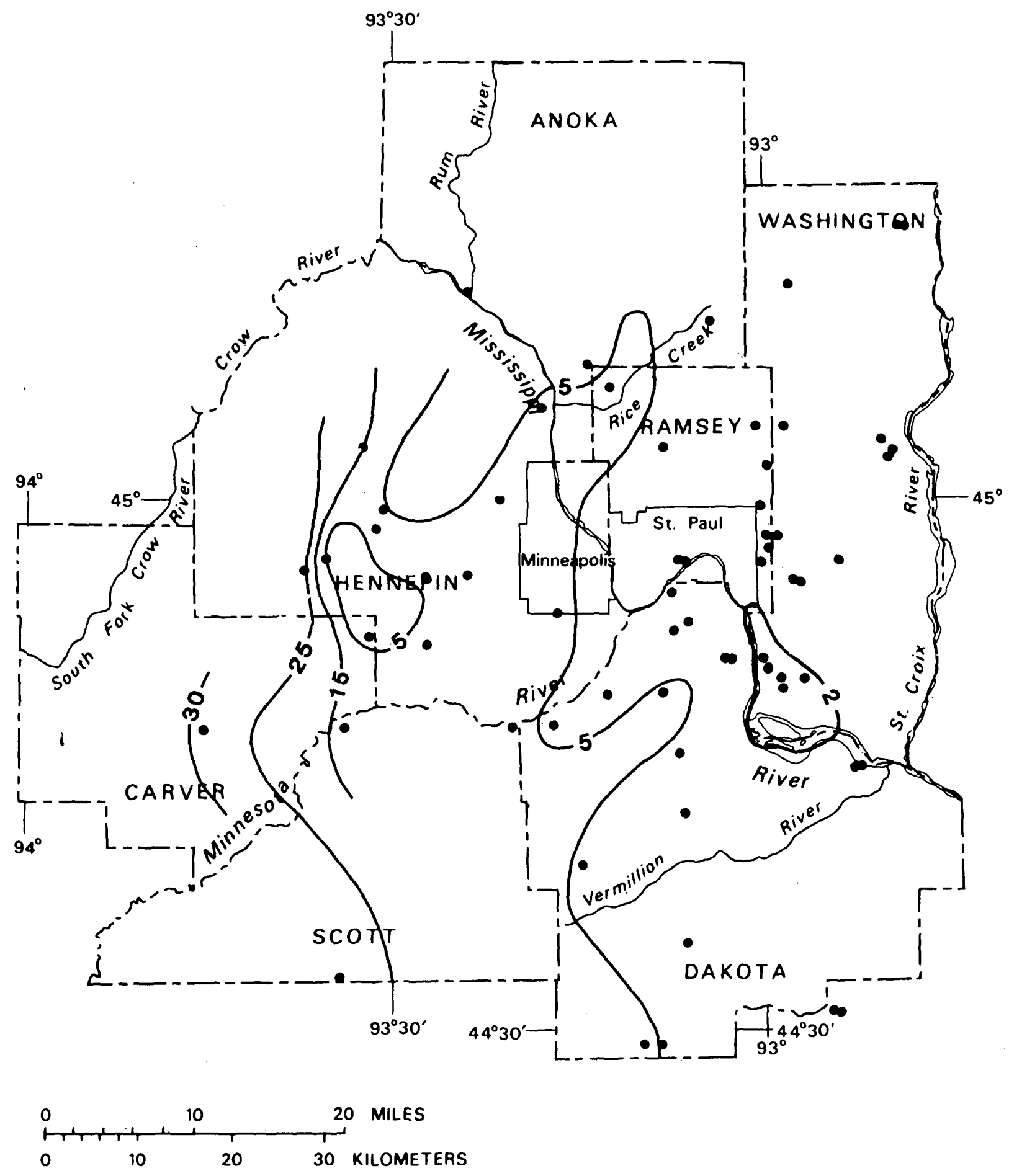

EXPLANATION

- 30 - LINE OF EQUAL DISSOLVED-SODIUM CONCENTRATION-Interval, in milligrams per liter, is 3,5 and 10

- Data point

Figure 39.--Lines of equal concentration of dissolved sodium in water from the Jordan Sandstone 


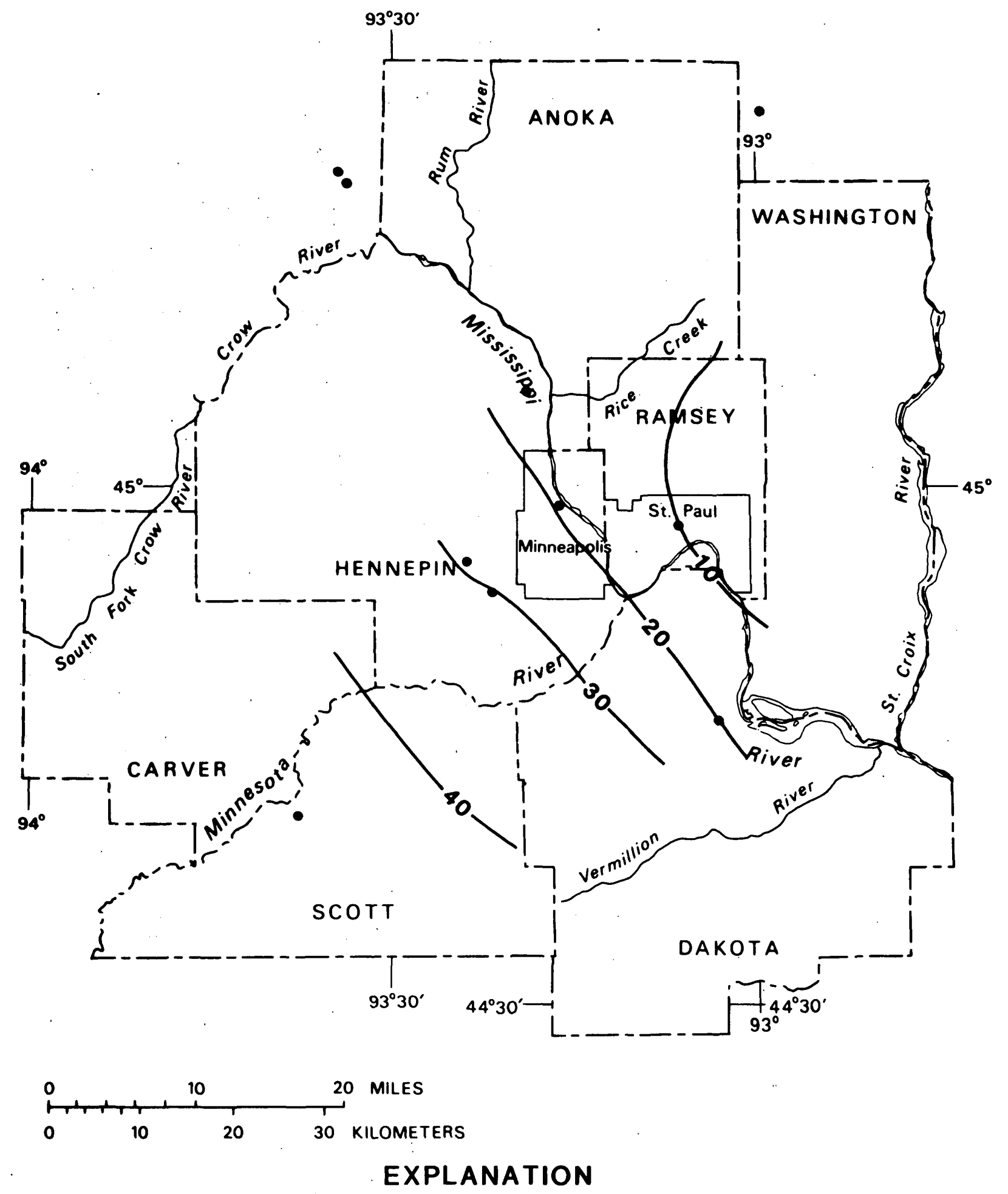

— 40 - LINE OF EQUAL DISSOLVED-SODIUM CONCENTRATION-Interval, in milligrams per liter, is 10

- Data point

Figure 40.--Lines of equal concentration of dissolved sodium in water from the Mount Simon-Hinckley aquifer. 


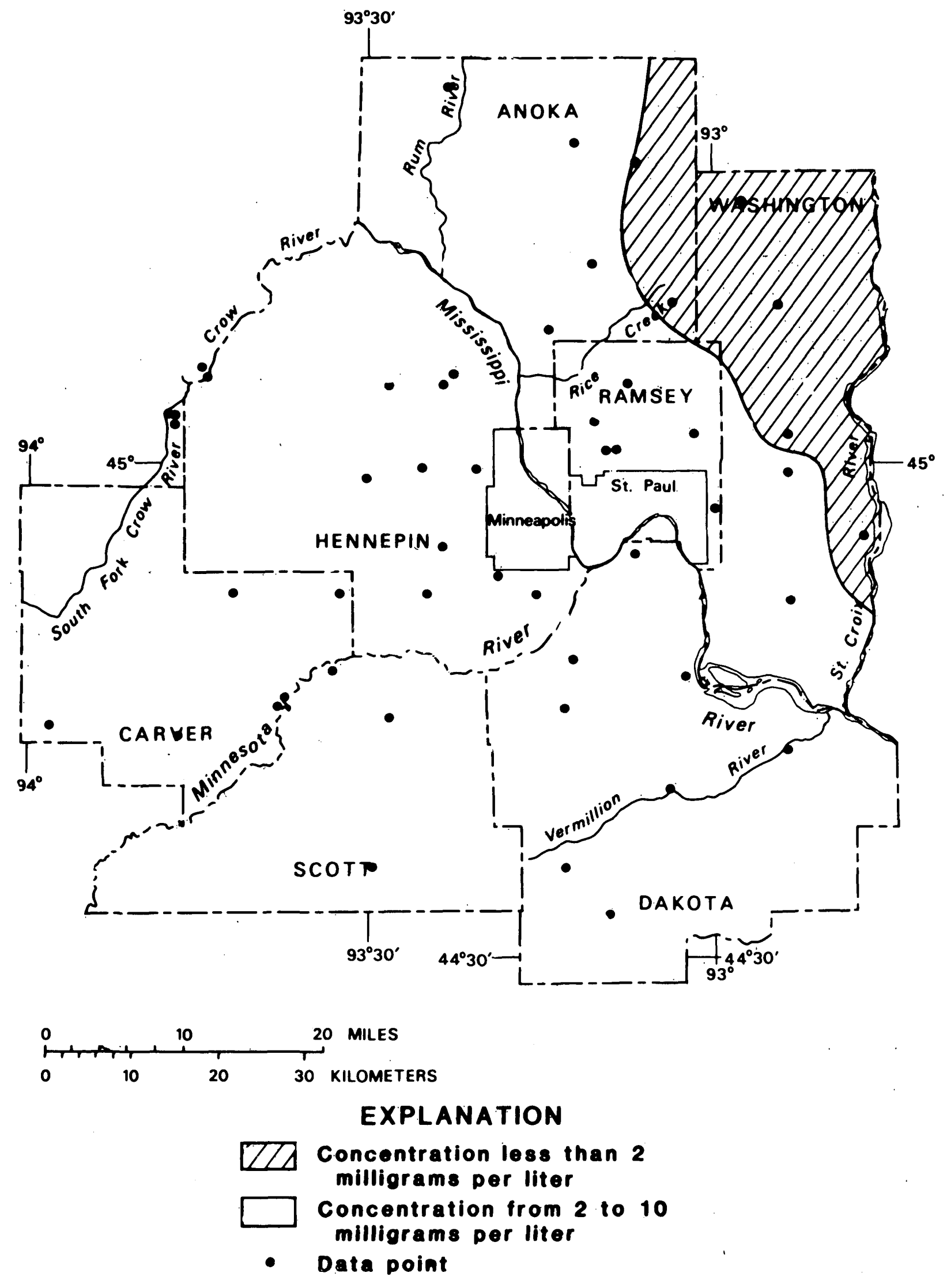

Flgure 41.--Concentration of chlorlde in water from the drift 


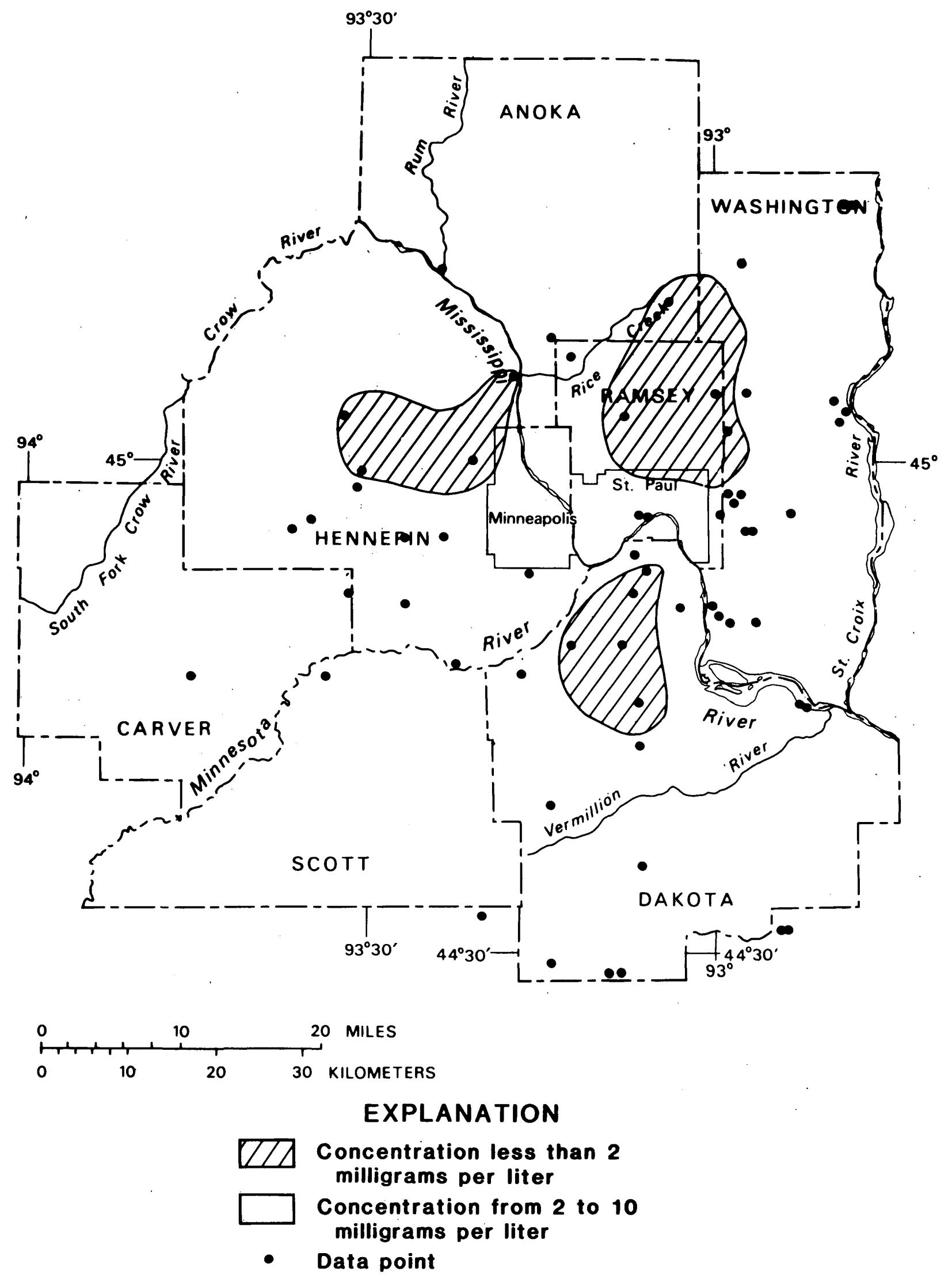

Figure 42.--Concentration of chloride in water from the Jordan Sandstone 


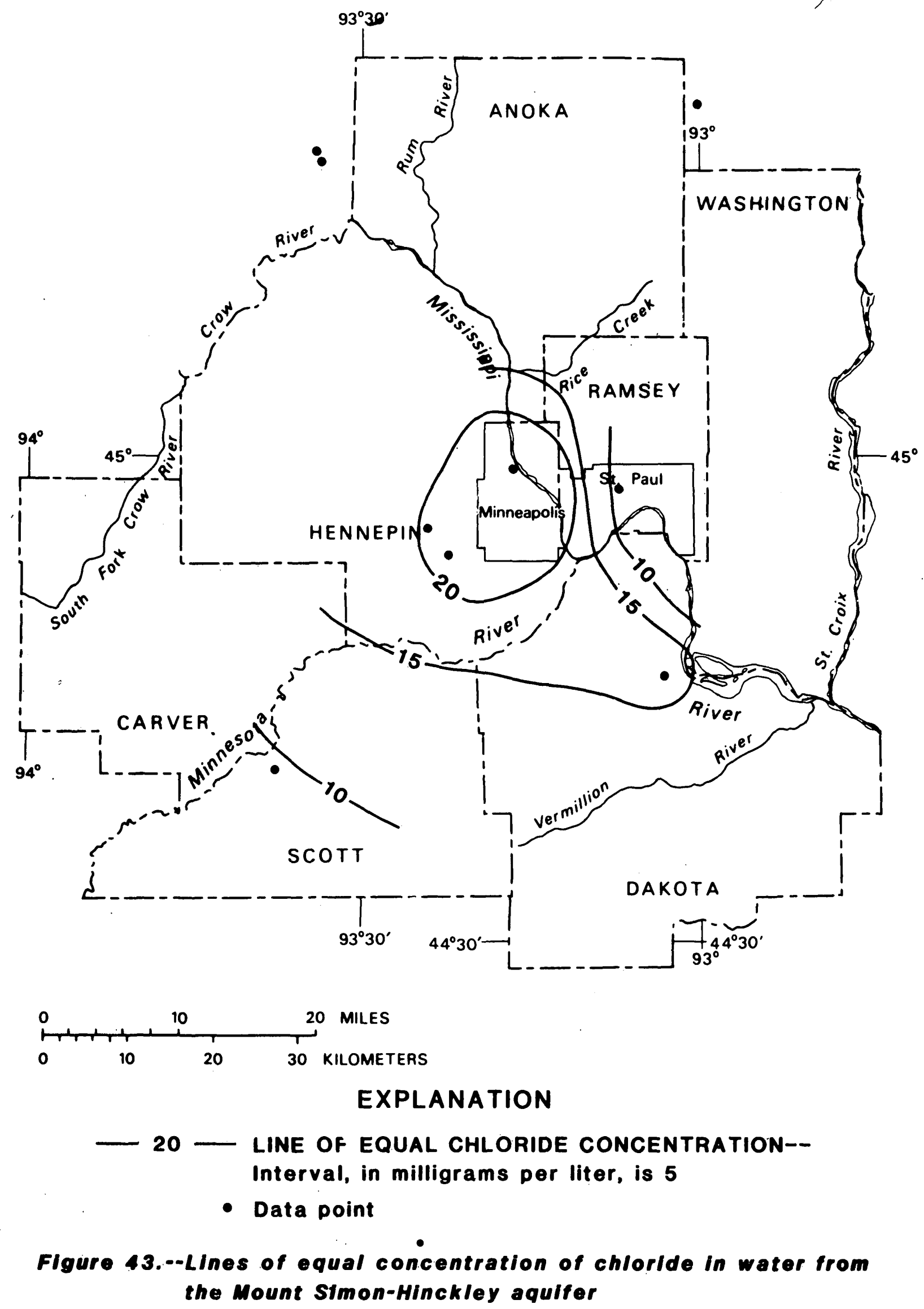


The differences in concentrations of sulfate, calcium, and sodium in water from the different aquifers could be caused by both lithological differences and geochemical processes in the aquifers. For example, the difference in sulfate concentration in water from drift and the underlying Jordan Sandstone probably is due to the chemical reduction of sulfate in drift water. This process could occur in the drift where the oxidation of organic material has removed dissolved oxygen from the water. Also, the decrease in dissolved calcium from west to east is probably because of (1) the dissolution of highly soluble carbonate minerals in the Des Moines Lobe drift, and (2) possible ion-exchange of calcium for sodium by clay minerals in the bedrock aquifers. Ion exchange may be the most likely reason why concentrations of calcium in water from the Mount SimonHinckley aquifer are less than those in the Jordan Sandstone in the western part of the study area, and why concentrations of sodium in the Mount Simon-Hinckley are generally higher than in water from overlying units.

\section{SUMMARY}

This report describes the results of the first phase of a three-phase study of the ground-water-flow system in the Twin Cities metropolitan area. This phase included the formulation of a conceptual model of the ground-water flow system, construction of a preliminary finite-difference ground-water-flow model, analysis of parameter and boundary-condition sensitivity, steady-state simulation of predevelopment conditions (approximately 1885) and a recent (1971-77) period, and description of the general quality of ground water in the Twin Cities area.

The nine hydrogeologic units included in the preliminary simulation model are the:

1. Mount Simon-Hinckley aquifer

2. Eau Claire confining unit

3. Ironton-Galesville aquifer

4. St. Lawrence-Franconia confining unit

5. Prairie du Chien-Jordan aquifer
6. Basal St. Peter confining unit

7. St. Peter aquifer

8. Decorah-Platteville-Glenwood

9. Drift confining unit

Hydrologic parameters and boundary conditions simulated in the preliminary flow model were derived from available information. Ground-water-withdrawal information was obtained from the Minnesota Department of Natural Resources, Division of Waters. Potentiometric data from about 500 wells were used to evaluate performance of the preliminary model. Sensitivity analyses were made on 19 model parameters and boundarycondition specifications. Model results are most sensitive to areal recharge rates, withdrawal rates, and the hydraulic properties of drift that fills or partly fills bedrock valleys. Model results also indicate that present (1980) uncertainties in estimated withdrawal rates and observed potentiometric levels may seriously affect model performance.

Areal distribution of dissolved constituents in ground water were analyzed to provide information on the hydrologic and geochemical relationships between aquifers. Concentration of dissolved solids in the Jordan Sandstone and Mount Simon-Hinckley aquifer generally decrease from southwest to northeast across the study area. This decrease probably reflects differences in the quality of recharge water and geochemical processes within the aquifers, such as ion-exchange. 


\section{PLANS POR PHASE II}

Based on analysis of the preliminary-model simulations, major effort during the second phase of this project will be directed toward improving estimates of ground-water withdrawals and evaluating the adequacy of observed potentiometric levels. The present (1980) procedure used by the Department of Natural Resources for collecting, storing, and analyzing water-use information is not adequate for the data needs of complex hydrologic investigations such as this project. For this study, improvements to the ground-water-withdrawal data base will include: (1) formation of a computerized data base, which contains information regarding well location, annual withdrawal rate, and aquifer identification to facilitate storage and retrieval of ground-water-withdrawal data; (2) tabulation and processing of detailed (at least seasonal) water-use information for the years 1970-79; (3) canvassing water users to evaluate the accuracy of reported water usage; (4) identification and (or) verification of aquifer designation; and (5) identification and (or) verification of well location and altitude. A separate report detailing ground-water withdrawals in the Twin Cities area will be prepared during phase II of the project.

The existing observation-well network will be evaluated to verify aquifer designation and measured water level. Wells with questionable measurements of potentiometric levels or uncertain aquifer designations will be eliminated from the data base. Fewer, but more reliable, potentiometric values will be more useful during calibration of the final model than many values of questionable reliability. Additional potentiometric-level information will be collected near the edges of the modeled area to help define boundary conditions for the flow model. An attempt will also be made to collect potentiometric information for the Ironton-Galesville aquifer to help develop an understanding of how this aquifer relates to the regional-flow system. A separate report describing and interpreting potentiometric levels in the Twin Cities area will be prepared during phase II of the project.

Water-quality information will continue to be collected and regional-flow patterns will be interpreted from dissolved-solids concentration. The samples will be collected to (1) fill in gaps in the existing water-quality data base and (2) provide a consistent set of water analyses with which to evaluate regional water quality at a single time. This work will be done in connection with the U.S. Geological Survey's Northern Midwest Regional Aquifer System Analysis (RASA) project.

A more detailed understanding of the nature and extent of buried valleys in the Twin Cities area would greatly improve the conceptual model of the ground-water-flow system. The considerable expense associated with the test drilling and sampling program necessary to provide this information is beyond the scope of this project. However, after improvement of the ground-water-withdrawal and potentiometric-level data bases, considerable insight into how buried valleys influence flow in the ground-water system will be gained by use of the simulation model.

\section{REFERENCES}

Bredehoeft, J. D., and Pinder, G. F., 1970, Digital analysis of areal flow in multiaquifer ground-water systems: a quasi three-dimensional model: Water Resources Research, v. 6 , no. 3 , p. 883-888. 
Maderak, M. L., 1963, Quality of water, Minnesota: A compilation, 1955-62: Minnesota Conservation Department, Division of Waters, Bulletin 21, 104 p.

1964, Relation of chemical quality of water to recharge to the Jordan Sandstone in the Minneapolis-St. Paul area, Minnesota: U.S. Geological Survey Professional Paper 501-C, p. C176-C179.

1965, Chemical quality of ground water in the Minneapolis-St. Paul area, Minnesota: Minnesota Conservation Department, Division of Waters, Bulletin 23, 43 p.

Megard, Robert, 1972, Phytoplankton photosynthesis, and phosphorus in Lake Minnetonka, Minnesota: Limnology and Oceanography, v. 17, p. 68-87.

Mossler, John, 1972, Paleozoic structure and stratigraphy of the Twin City region: in Sims, P. K., and Morey, G. B., eds., Geology of Minnesota: A centennial volume: Minnesota Geological Survey, 632 p.

Norvitch, R. F., and Walton, M. S., 1979, Geologic and hydrologic aspects of tunneling in the Twin Cities area, Minnesota: U.S. Geological Survey Miscellaneous Investigations Map I-1157.

Norvitch, R. F., Ross, T. G., and Brietkrietz, Alex, 1973, Water resources outlook for the Minneapolis-St. Paul metropolitan area, Minnesota: Metropolitan Council of the Twin Cities Area, 219 p.

Novitzki, R. F., Van Voast, W. A., and Jerabek, L. A., 1969, Water resources of the Yellow Medicine River watershed, southwestern Minnesota: U.S. Geological Survey Hydrologic Investigations Atlas HA-320.

Prior, C. H., and others, 1953, Water resources of the Minneapolis-St. Paul area, Minnesota: U.S. Geological Survey Circular 274, 49 p.

Reeder, H. O., Wood, Warren W., Ehrlich, Garry G., and Sun, Ren Jen, 1976, Artificial recharge through a well in fissured carbonate rock, West St. Paul, Minnesota: U.S. Geological Survey Water-Supply Paper 2004, 80 p.

Sims, P. K., 1970, Geologic map of Minnesota: Minnesota Geological Survey Miscellaneous Map Series, Map M-14.

Sims, P. K., and Morey, G. B., editors, 1972, Geology of Minnesota: A centennial volume: Minnesota Geological Survey, 632 p.

Stone, John E., 1965, Status of urban geology in the Minneapolis-St. Paul area: Minnesota Geological Suvey, Reprint series-2, 13 p.

Trescott, P. C., 1975, Documentation of finite-difference model for simulation of threedimensional ground-water flow: U.S. Geological Survey Open-File Report' 75-438, 30 p.

Trescott, P. C., and Larson, S. P., 1976, Supplement to Open-File Report 75-438, Documentation of finite-difference model for simulation of three-dimensional groundwater flow: U.S. Geological Survey Open-File Report 76-591. 
Trescott, P. C., Pinder, G. F., and Larson, S. P., 1976, Finite-difference model for aquifer simulation in two dimensions with results of numerical experiments: U.S. Geological Survey Techniques of Water-Resources Investigations, Book 7, Chapter C1, 42 p.

Van Voast, W. A., Broussard, W. L., and Wheat, D. E., 1972, Water resources of the Minnesota River-Hawk Creek watershed, southwestern Minnesota: U.S. Geological Survey Hydrologic Investigations Atlas HA-391.

Winter, T. C., 1964, The natural quality of ground water in Minnesota: Minnesota Department of Natural Resources, Bulletin 26, 25 p. 